\title{
VADJA LOODUS- JA VILJELUSNIMEDEST
}

\author{
Enn Ernits \\ Eesti Maaülikool
}

\begin{abstract}
Kokkuvõte. Vadja toponüüme koguti süstemaatiliselt XX sajandi teisel poolel. Sellest ajast pärinevad Eesti Keele Instituudi ja Emakeele Seltsi kohanimekogud. Siinkirjutajal õnnestus aastatel 2001-2004 panna kirja kõigest 40 kohanime. Vadja toponüümikat on seni uurinud peamiselt Paul Ariste. Käesoleval sajandil on väheste toponüümide algupära käsitlenud üksnes Leningradi oblasti Kingissepa rajooni asjaarmastajad. Käesolevas kirjutises, mis lähtub peamiselt mainitud kogudest ning käsitleb loodusja viljelusnimesid, on põhitähelepanu pööratud kohanimede päritolule. See võimaldab paigutada nad atribuutide ehk täiendosade järgi tähendusrühmadesse. Uurimuses tehakse kindlaks samuti kohanimede determinandid ehk liigisõnad. Tähelepanuta ei jää ka nende morfoloogilised iseärasused. Vadja keeles leidub nii primaarseid kui ka sekundaarseid kohanimesid, sageli on kirja pandud ka determinandita toponüüme, samuti üksikuid terminnimesid. Loodus- ja viljelusnimed on päritolult üsna sarnased. Nad on arenenud looduskogumeid, loomi, taimi, omadusi, asendit jt aspekte tähistavatest apellatiividest, tulenedes mõnikord ka reaalsete isikute või pühakute nimedest. Toponüümide moodustamise printsiibid sarnanevad teiste läänemeresoome keelte kohanimede moodustamise põhimõtetega. Nimede atribuut esineb peamiselt ainsuse nimetavas ja omastavas, determinant aga tavaliselt ainsuse ja harva mitmuse nimetavas käändes. Üks ja sama toponüüm võib mõnikord tähistada heinamaad, sood, metsa ja põldu. See näitab nende kunagist vahelduvat kasutusala. Kohanimede päritolu uurimisel on selgunud hulk üldnimesid, mida pole registreeritud väljaspool toponüümikat.
\end{abstract}

Märksõnad: kohanimed, loodusnimed, viljelusnimed, etümoloogia, vadja keel, läänemeresoome keeled

DOI: https://doi.org/10.12697/jeful.2020.11.1.08

\section{Sissejuhatus}

Inimest ümbritsevat keskkonda saab käsitleda mitmeti liigendatud ruumiliste struktuuridena - maastikena. Eristatakse loodus- ja kultuurmaastikke. Käesolevas uurimuses võetakse vaatluse alla kõik vadja loodusmaastike nimed. Kultuurmaastiku osadest käsitletakse üksnes viljeldavaid objekte: põlde, heinamaid, karjamaid. Igas alarühmas 
eristatakse primaarseid ja sekundaarseid toponüüme; tertsiaarsed jne kohanimed on vaikimisi paigutatud enamasti sekundaarsete alla.

Vadja toponüümikat on seni uurinud peamiselt vaid fennougrist ja votoloog Paul Ariste. Tema esimene selleteemaline kirjutis Jarvikoisjarvi nime päritolust ilmus 1964. aastal (Ariste 1964). Autor seostas järve ja sellest lähtuva külanime veehaldjaga. Järgmisel aastal ilmus P. Ariste sulest pikem kirjutis vadja-täiendosast Eesti ja Ingerimaa kohanimedes (Ariste 1965a). Selgub, et teadlane tegeles 1960. aastatel hoogsalt igat tüüpi vadja kohanimedega, millest annab tunnistust ettekanne teisel rahvusvahelisel soome-ugri kongressil (Ariste 1965b) ning kaks artiklit (Ariste 1967, 1968). Teistest põhjalikumalt on P. Ariste käsitlenud asulanimesid.

Käesoleval sajandil on väheseid vadja toponüüme käsitlenud Leningradi oblasti Kingissepa rajooni asjaarmastajad, kes pole paraku suutnud teemasse vajalikul tasemel süveneda. Vadja alasid puudutavad Kattila kodu-uurija Tamara Barabaši ja Jõgõperä keskkooli õpilase A. K. Baranovi pealkirjata lühikirjutised (Demina 2009). Märkimist väärivad viimase kogutud kohanimed, mis annavad aimu sellest, millised toponüümid on kindlasti millenniumi piiri ületanud. Asustusnimede ajalugu on pikemat aega uurinud Peterburi Polütehnilise Ülikooli dotsent Aleksandr Dmitrijev (nt Dmitriev 2007).

Esimesed vadja alade kohanimed, tõsi küll, venepärasel kujul, nt Lauga jõe nimi, on kirjasõnasse sattunud juba kolmveerand tuhande aasta eest. Süstemaatiliselt hakati neid koguma alles XX sajandi teisel poolel. Sellest annab tunnistust kaks kogu, mida säilitatakse Tallinnas Eesti Keele Instituudi kohanimekartoteegis. Esimene (639 nimesedelit) neist on Eesti Keele Instituudi anonüümne, tõenäoliselt 1960. aastatest pärinev kogu, mis sisaldab ainest kõigilt murdealadelt, sh ka kirjandusest avaldatud vadja tekstidest nopitud toponüüme; nende ebatäpsusi sedelitel on pärastpoole agaralt korrigeeritud. Teine on Emakeele Seltsi kogu, mille 317 sedelit on talletanud A. Lõhmus 1972. aasta suvel Mati külast ja kogu Vaipoolest. Kohanimesid sisaldavad ka Eesti Keele Instituudi eesti murrete ja soome-ugri keelte arhiivi (EMSUKA) helisalvestised. ${ }^{1}$ Siinkirjutaja kogus aastatel 2001, 2003 ja 2004

Tänan siinkohal Tartu Ülikooli Viljandi Kultuuriakadeemia lektorit Taisto-Kalevi Raudalainenit, kes juhatas mu EMSUKA juurde ja andis lahkelt kasutada vadja tekstide litereeringuid, samuti anonüümseid retsensente, kelle väärtuslikud näpunäited aitasid kirjutise muuta sisukamaks ja terminoloogiliselt kaasaegsemaks. 
Jarvikoisčüläst, Kukkuzist, Kõrvõttulast ja Rajolt kõigest 40 toponüümi, neistki oli osa moondunud ja osa puhul tähistatav objekt ununenud.

Ühel või teisel määral sisaldavad toponüümikat ka Talve 1981 ja vadja sõnaraamatud (Posti 1980, Kettunen 1986, Tsvetkov 1995, VKS). Kõige rikkalikum on selle poolest Lauri Posti sõnaraamat, mis sisaldab üle 80 Kukkuzi kandi loodus- ja viljelusnime, lisaks veel küla- jm nimesid. Rohkesti toponüüme kätkeb P. Ariste 18 mapist koosnev käsikirjaline kogu „Vadja etnoloogiat“. Üksikuid kohanimesid võib leida publitseeritud vadja tekstidest ja ilmselt mujaltki.

Kirjutises on vadja loodus- ja viljelusnimede käsitlemisel esile toodud nii isuri, soome kui ka eesti paralleele. Viimasel juhul on ruumi ja aja puudumisel piirdutud üksnes vadja, isuri ja soomemõjuliste murrakutega. Eesti Keele Instituudi kohanimekartoteegis leiduva idamurde (edelaosa Iis, Kod, Trm) ja kirderanniku murrete (Jõh, ülejäänud Iis, Vai) ainesega on võrreldud ainult omapärasemaid vadja toponüüme. Pooltosinal korral on kasutatud Julius Mägiste poolt Eesti-Ingerist kogutud, üksteisest eristamata isuri ja soome kohanimesid, mis on kartoteegis paigutatud Vaivara murraku kasti.

Vadja kohanimesid on võetud kõigist eespool mainitud allikatest, v.a publitseeritud tekstid, kus leidub, tõsi küll, vaid üksikuid toponüüme. Kohanimede päritolu kindlakstegemisel kasutatakse läbivalt VKSi koondatud sõnavara, isurite näidete puhul lähtutakse peamiselt IMSist, soome kohanimeparalleelid võetakse SPKst, vene nimevaraga võrdlemisel lähtutakse vene eesnimede sõnastikust (Petrovskij 1966). Vadja või isuri üldsõnade kasutamisel kirjutises jäävad tsiteerimisallikatena märkimata nii VKS kui IMS. Samuti ei viidata viimati mainitud teosele selles leiduva kohanime esitamisel, v.a juhul, kui toponüüm ei esine iseseisva märksõnana.

Enamik vadja toponüüme, paraku mitte kõik, on varustatud külanime lühendiga, millele on ruumi kokkuhoiu mõttes lisatud allikas indeksina (vt lühendid). Külanime lühend osutab keelejuhi elukohaks olevale külale. Tähtsamaid kohanimesid, sh külanimesid aitab lokaliseerida kaart (joonis 1) vadjakeelsete küla- ja loodusnimedega. Võib vaadata ka kaarti vadja keele sõnaraamatus (VKS: 94). Paljud kirjutises käsitletavad Soome lahe saared ja laiud on leitavad kaardilt 2 ja rootsikeelsete nimedega Stockholmis üllitatud kaardilt 1788. aastast (CFV).

Teadmata küla nimi tähistatakse $X$-ga. Tärn * vadja üldsõna ees viitab selle puudumisele VKSis. Külanimi sulgudes osutab sellele, et 


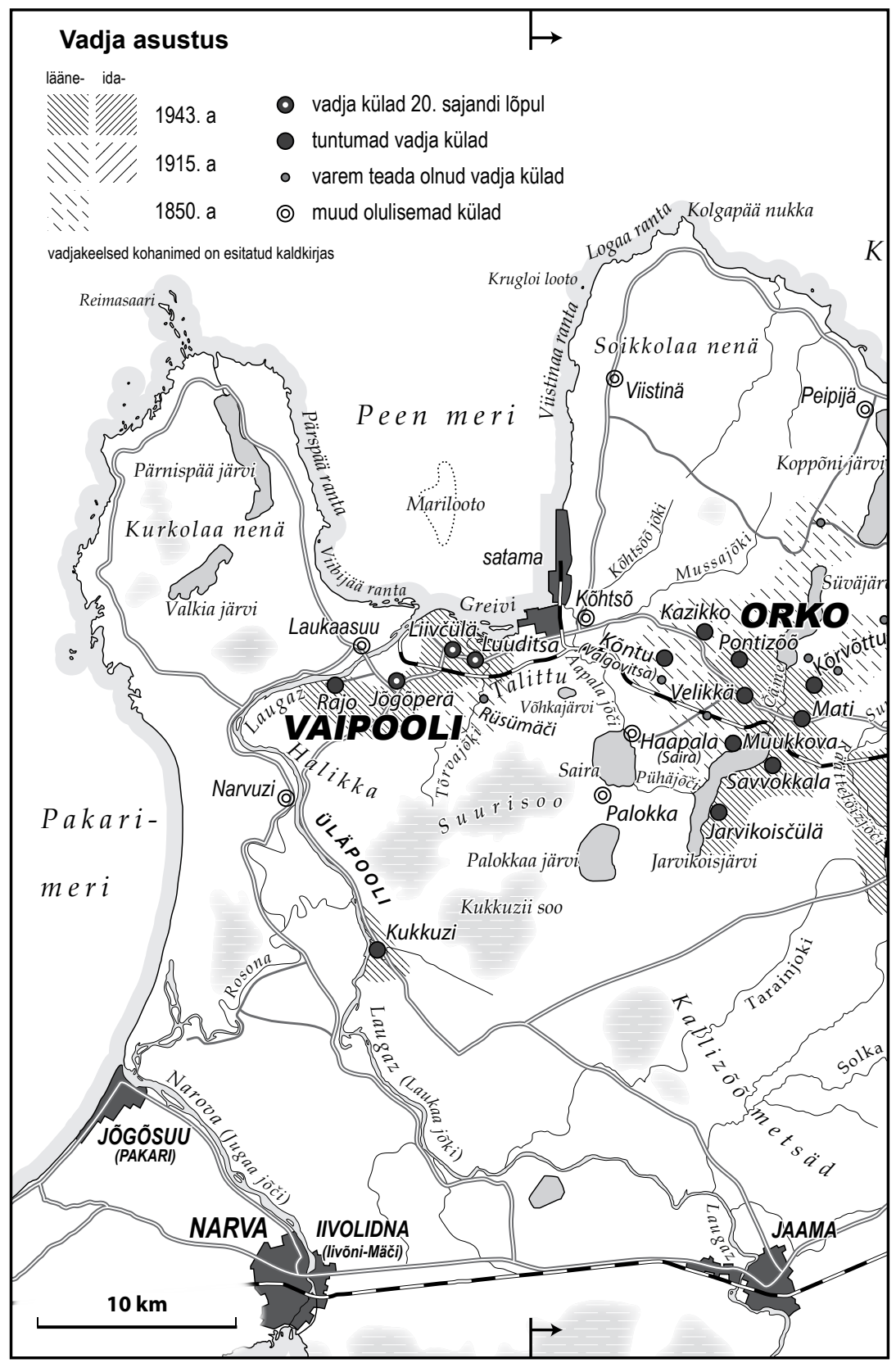




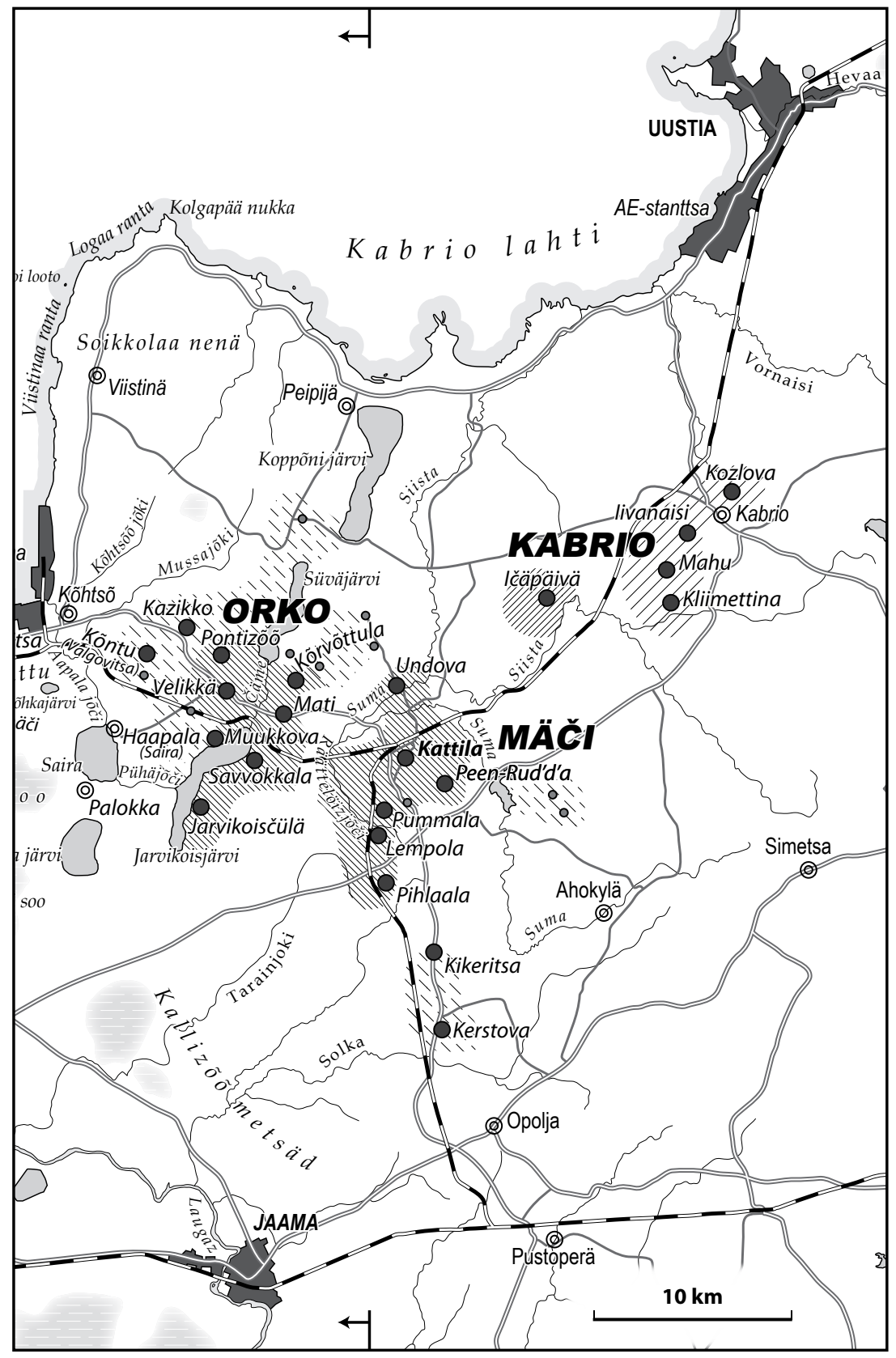

Joonis 1. Vadja asustus- ja loodusnimed. Kaardi autor on Raivo Aunap. 
talle järgnev kohanimi pole algselt kirja pandud nominatiivis. Kirjasõnast sedeldatud kohanimedel on Eesti Keele Instituudi kartoteegikaartidel lisatud viide algallikale (autor, ilmumisaasta, lehekülg); käesolevas kirjutises piirdutakse vaid autorinimega, mis järgneb külanimele sidekriipsu abil. Vajadusel võib huviline lähemaid andmeid leida kõnealusest kohanimekartoteegist.

Kohanimele on võimaluse korral lisatud selgitus, mis aitab seda lokaliseerida. Alati pole olnud võimalik sedastada, kas ühele kohanimele vastab üks või rohkem objekte, sageli selgitus üldse puudub. Seepärast pole selgitusi tõstetud ühe ja sama toponüümi viimase variandi juurde, vaid on säilitatud koos nimeteisendiga. Puhuti on nime seos objektiga jäänudki ähmaseks. Venekeelsete nimetuste kuju täpsustamisel on abiks olnud Leningradi oblasti atlas (JZL) ja vähesel määral Petersson 2003: 28-29. Siinkirjutaja täiendused on mitmel juhul eristatavad nurksulgude järgi.

Vadja toponüümide kirjapilti on ühtlustatud ja lähendatud kirjakeelele, kusjuures on tehtud järgmised muudatused: $c \rightarrow t s, c c \rightarrow t t s$, $t \check{s} \rightarrow \check{c}, t t \check{s} \rightarrow \check{c} \check{c}$ ning Kattila ja Kabrio murde nõrgas astmes geminaate ei tähistata. Ka isuri näidete transkribeeritud kujusid on välditud, kusjuures eesti keele konsonantidega sarnased poolhelilised klusiilid $G, B, D$ on asendatud tähtedega $g, b, d$. Kirjas ei tähistata vokaalide kõrgenemist. Genitiivilõpu assimilatoorsed kujud on säilitatud, nt Soomel lahti teoreetiliselt $n$-lõpulise Soomen lahti asemel.

Artiklis on peatähelepanu pööratud kohanimede päritolule. See võimaldab paigutada kohanimed atribuutide ehk täiendosade järgi tähendusrühmadesse. Vadjamaa mitmekeelses olustikus on sageli võimatu määrata täiendosade keelelist kuuluvust. Öeldu kehtib võimalike isuri ja ingerisoome laenude kohta, kuid ei puuduta vene laene. Väga tihti on raske leida nimemotiivi, sest Vadjamaal pole enam neid, kes võinuks koguja kohapeale nimeobjekti vaatama juhatada. Uurimuses tehakse samuti kindlaks kohanimede determinandid ehk liigisõnad. Mööda ei vaadata ka toponüümide morfoloogilistest iseärasustest. Artikli kirjutamisel, eriti liigitamisel, on arvestatud Eesti kohanimeteaduse seisukohtadega (vt Päll 2020; Saar 2009). 


\section{Maismaavormide nimed}

Sellesse rühma liigitatakse metsade, soode, mägede, orgude, nõmmede ja kivide nimed.

\subsection{Metsanimed}

Vadja metsanimede liigisõnaks on harilikult mettsä 'mets'. Primaarnime atribuudiks võib olla looduslik kogum, sh mõni metsaliik puude järgi: Lu ${ }^{\mathrm{ES}}$ Kazikoo mettsä 'mets Lauga jõe idakaldal mere ääres', $\mathrm{Vp}^{\mathrm{B}}$ Казикомется [Kazikomettsä] 'metsatukk Luuditsa küla otsas' < kazikko 'kaasik'; Lu ${ }^{\mathrm{ES}}$ Katazikoo mettsä 'mets Luuditsast Rüsümäe poole' $<$ katazikko 'kadastik'. Kindel pole $\mathrm{Ku}^{\mathrm{P}}$ Hirzikko 'mingi mets ja heinamaa' < ?*hirzikko 'palgistik; palgimets' < irsi 'palk' (vrd ka Vai Irsiku (talu)); keelejuhi arvates tulenevat see hoopis üldsõnast ?*hirvizikko 'põdrakari' < irvi 'põder'. Loomanimetusega seostub Lu ${ }^{\mathrm{EK}}$ Karupesä (mets) $<$ karu + pesä 'pesa' ning samuti ehk Ku Tallikka $<$ tallikka tallikkõ 'lambatall' (vrd ka ee tallikavill 'tallevill', VMS II: 483; Tallika Setumaal, EKNR: Sorahkna), vrd ka vdj tallikkaina 'keskmise suurusega'. Tallikka puhul võiks arvesse tulla samuti Ida-Soome isikunimi Talikka (vt SSN: Taalikka, Talka).

Asendist sõltuvalt on nimetatud $\mathrm{Ku}^{\mathrm{P}}$ Kalmmetsä (võimalik ka, et metsas leiduva kalmu järgi; esineb samuti põllunimes, vt 5.1); $\mathrm{Lu}^{\mathrm{ES}}$ Kalmojõõ mettsä 'mets Luuditsa kalmistu taga' < kalmod 'kalmistu' $<$ kalmo 'kalm, hauaküngas'; $\mathrm{Li}^{\mathrm{EK}}$ Kuru mettsä, $\mathrm{Li}^{\mathrm{A} 1} \mathrm{Lu}^{\mathrm{L}} \mathrm{Li}^{\mathrm{A} 1} \mathrm{Li}^{\mathrm{EK}}$ $\mathrm{Li}^{\mathrm{ES}}$ Kurumettsä 'mets Tõrvajõe ääres' < *kuru 'kuru, kõrvaline paik' (vaevalt siis, et sõnast kuru '(konna)kudu'); Lu ${ }^{\mathrm{EM}}$ Meri-saarõõ-mettsä $<$ meri + saari 'saar'.

Inimese nime, tiitlit või ametit sisaldavad $\mathrm{Ku}^{\mathrm{P}}$ Graafii mettsä < graafi 'krahv'; Kõ $\tilde{\mathrm{E}}^{\mathrm{E}}$ Malengóf 'mingi mets'; $\mathrm{M}^{\mathrm{EK}}$ Mal'ingovaa mettsä 'mets viie versta kaugusel Matist' < perekonnanimi Malenkov (VKS: 903 järgi, ent vaevalt et kohanimi Malinkovo); J ${ }^{\mathrm{Al}}$ Morofkaa metts $\ddot{a}<$ ? isikunimi, vrd vn perekonnanimi Моровкин; $\mathrm{M}^{\mathrm{Al}} \mathrm{M}^{\mathrm{EK}}$ Paturimettsä 'mets Mati-Velikkä tee ääres vasakut kätt' < paturi 'pottsepp'. Teisalt pole võimatu, et toponüüm seondub seni registreerimata vadja maastikusõnaga * paturi, vrd ee padur : padura paduri 'pehme, soine maa'. See on üldsõnana talletatud küll ainult Läänemaalt (EDW: 746), kuid sõna idapoolsemale levikule osutab Virumaa kunagise kõrvalmõisa nimi Paduri, mida on ühendatud eesti keeles ainult oletatud, pottseppa 
tähendava sõnaga (EKNR: Vila). Maastikusõna sobiks nii eesti kui ka vadja toponüümis paremini.

Muud päritolu on $\mathrm{Ku}^{\mathrm{P}}$ Kaivatavaa mettsä, $\mathrm{Ku}^{\mathrm{E}}$ Kaivtava $<$ kaivattava 'kaevatav'. Kui atribuudi järgsilbi pikk vokaal on ebatäpsus, siis on mõeldav tähendus 'mets, kus kaevatakse midagi'. Oleviku partitsiipi $-v a \sim-v \ddot{a}$ esineb nii eesti (eriti Vaivara murrakualal) kui ka soome kohanimedes, nt ee Liekova (soo), Läbikäidav (heinamaa), Ülekäidavpöld ja Üllüvä (soo) ning sm Kerittävä (noodatõmbamise koht) < keriä 'erilisel viisil võrguga kalu püüdma', samuti Ylikäytävä 'ülekäidav' (Kallasmaa 2003: 43; EKNR: Leekova; SPK: Keritty). Atribuudi tähenduse poolest jäävad arusaamatuks $\mathrm{M}^{\mathrm{EK}}$ Kallin $\sim$ Kallizõ̃ metsäd 'suured metsad Mati külast 15 versta Kingissepa ja Lauga poole'; $\mathrm{M}^{\mathrm{A} 1} \mathrm{M}^{\mathrm{EK}}$ Pomarikoo mettsä 'Matist Kattilale viiva tee ääres vasakut kätt asuv mets' (vrd $\mathrm{Lu}^{\mathrm{EK}}$ Pumarikko 'koht Kõrvõttula küla ja Süväjärve lähedal') ning $\mathrm{Lu}^{\mathrm{EK}}$ Talittu mettsä, $\mathrm{Ku}^{\mathrm{P}}$ Talituu mettsä $\sim$ Talittu mettsä. Täiesti isepärane metsanimi on $(\mathrm{Lu})^{\mathrm{EK}}$ Nurkkasammaz $<$ nurkka 'nurk; maatükk, maanurk' + sammaz 'sammas; mesitaru'.

Atributiivne Talittu esineb nii metsa-, soo- kui ka järvenimes (vt ka 2.2. ja 4.3), mistõttu tegu on ilmselt maakoha nimega, mille jälgitavaks orientiiriks Leningradi oblasti kaardil on Leši ehk Talittu järv loode pool Saira ehk Habolovo järve (vt JZL: 17). Sõnatüve algupära on tume. -ttu ( - -ttü) on umbisikulise tegumoe mineviku kesksõna tunnus. ${ }^{2}$ Seda esineb vähesel määral nii eesti kui ka soome kohanimedes, nt ee Kaevatumägi ja Tapetmehesihk ning sm Keritty (järv) < keriä 'erilisel viisil võrguga kalu püüda' ja Pyhitty (järv) < pyhittää 'pühitseda' (Kallasmaa 2003: 44-45; SPK).

Talletatud on kaks metsasaare nime, millest $\mathrm{Ku}^{\mathrm{P}}$ Hootarisürgü 'kaardil: Otrasaari [Soome vetes]' võib olla ühenduses karjalapärase soome perekonnanimega Huotari < mehenimi Федор (SSN: 321; vrd E-Ing Huoterin sürjä 'tükk kroonumetsa Naroova vallas'; sürgü kohta vt 2.2), ja Li ${ }^{\mathrm{EK}} \mathrm{Lu}^{\mathrm{EK}}$ Loppi-saari 'koht Liivčülä lähedal metsas' < loppi '(adra) lusikas' (kuju järgi?). Viimasel juhul võib oletada ka hääbunud üldsõna *loppi, vrd sm loppi 'sopp', mis esineb soome kohanimedes Loppi ja Tohloppi ning oletatavasti kunagises eesti külanimes Lopi (SPK; EKNR: Kiideva ja Koidu). Siinkohal olgu nimetatud veel paar metsas

Erinevalt eesti keelest ei lange vadja kesksõnatunnus ja adjektiiviliide kokku, viimane on -toi $\sim$-toin $\sim$-too (nt õnnõtoi jt 'õnnetu'). 
asuvat kohta või objekti: $\mathrm{X}^{1}$-Ariste Čirpuu kuusi 'kõrgeim puu Jõgõperä ümbruses' < čirppu 'kirp' + kuusi 'kuusk'; Ja ${ }^{\mathrm{T}}$ Iilia kahči 'ohvripuu' < Iiliä '(püha) Elias' (vrd vn Илья) + kahči 'kask'; Lu ${ }^{\mathrm{EK}}$ Karupers 'koht metsas Rüsümäe küla taga'< karu 'karu' + perz perze 'tagumik'. Eesti karuperse on tuntud üle Eesti unka nimetusena, kohanimedes tähistab ta kas heinamaad (Jõh, Kod, Lüg) või väikest küngast heinamaal ja metsas (Jõh, Vai; VMS I: 182; EK). ${ }^{3}$

Struktuurilistest iseärasustest mainitagu järgmisi. Determinandita metsanimed on Kallin, Karupesä, Nurkkasammaz ja Tallikka. Terminnimede hulka võib ehk küsimärgiliselt paigutada Hirzikko. Ühe näite saab esitada paralleelselt kasutatud ainsuse nimetavalise ja omastavalise atribuudi kohta (Talittu mettsä $\sim$ Talituu mettsä). Toponüümis Kallizõ $\tilde{o}$ metsäd on liigisõna mitmuses. Kohanimes Kalmojõõ mettsä on täiendosa mitmuse omastavas käändes.

Sekundaarsete toponüümide hulka kuuluvad metsanimed sisaldavad teiste loodusobjektide (soo, mägi, oja, abajas vms) nime: $\mathrm{Ra}^{\mathrm{EK}}$ Muusaa mettsä (vt 3.1, 4.3, 4.4 ja 5.2); Li ${ }^{\mathrm{EK}}$ Polma-soo, Li ${ }^{\mathrm{ES}}$ Polmasoo mettsä 'mets Liivčüläst Lauga poole viiva tee ääres'; Lu-Li ${ }^{\mathrm{A} 1}$ Polmõsoo mettsä (kohanimekartoteegis soonimena puudub; vt 2.2 ja 5.1); $\mathrm{Ku}^{\mathrm{P}}$ Suteselää mettsä (kohanime Suteselkä pole registreeritud; vt 2.1, 2.3 ja 5.1)'; $\mathrm{Li}^{\mathrm{EK}}$ Võd'd'apaija, $\mathrm{Li}^{\mathrm{A} 1}$ Võd'd'e-apaja, Lu ${ }^{\mathrm{A} 1}$ Võd'd'a a apaja 'mets Liivčülä lähedal' (vt 4.1); Lu-Li ${ }^{\mathrm{A} 1}$ Võhkajärvee mettsä (vt 4.3). Tertsiaarseks osutub Lu ${ }^{\mathrm{ES}}$ Leppõjaa nurkka 'mets Luuditsa külast ida poole' < leppä 'lepp' + oja 'oja' + nurkka 'nurk (mitmes tähenduses)' (kartoteegis ojanime pole; vt 4.5). Kirjeldava iseloomuga on $\mathrm{Lu}^{\mathrm{ES}}$ Võhkõojärvii mättää päällä mettsä 'mets Võhkjärve ääres'. Neist Polma-soo ja Võd'd'apaija on determinandita. Viljelusnimega seondub teisene (Ra) Ем Leht-niitüü-mettsä (vt 5.2).

Osa teiseseid metsanimesid, nagu $\mathrm{Li}^{\mathrm{EK}}$ Jõgõperää mettsä; $\mathrm{Lu}^{\mathrm{A} 2}$ Kukkuzii mettsä; Lu ${ }^{\mathrm{EK}}$ Kõhtsa mettsä; Lu ${ }^{\mathrm{EK}}$ Liivčülää kuruumettsä 'mets Liivčülä vastas Tõrvajõe teisel kaldal'; Lu ${ }^{\mathrm{EK}}$ Luškii mettsä; $\mathrm{Lu}^{\mathrm{ES}}$ Luutsaa kuruumettsä 'mets Luuditsa vastas teisel pool Tõrvajõge'; (Ra) ${ }^{\mathrm{EM}}$ Rajoo-mettsä; Lu ${ }^{\mathrm{EK}}$ Risumäe mettsä (külanimi ise tuleneb mäenimest); $(\mathrm{Ra})^{\mathrm{EM}}$ Taga-väl'l'ää-mettsä; $\mathrm{M}^{\mathrm{A} 2}$ Vilikkaa mettsä seostuvad külaga, mille koosseisu nad kuuluvad või mille juures paiknevad. Omaniku

Järelosis tähistab märga heinamaad (Päll 2020: 303). Küngaste nimetused võivad seostuda objekti kujuga. 
nime ja objektiga seonduvad $\mathrm{M}^{\mathrm{A} 1}$ Karpaa müllüü mettsä $<$ mehenimi Karppa (< vn Kapn; Saar 2016: 169) + müllü 'veski' ja Lu' ${ }^{\mathrm{ES}}$ Van'aa laitaa mettsä 'mets Lauga idakaldal' (vt 5.1).

\subsection{Soonimed}

Soonimede determinandiks on soo, ainult üht sood Kabrio murdealal nimetatakse teisiti (Karetii mätä), kusjuures selles tähenduses ('mädasoo'?) sõna VKSis puudub. Kukkuzi soosaarte nimes võib saari kõrval esineda murdesõna *sürgü 'soosaareke, kõrgem koht soos', mille Jõgõperä vaste on sürjü, vrd is sürjü 'kõrgem koht madala maastiku keskel', Suurensoonsürjü, Välisoonsürjü (IMS: sürjü). ${ }^{4}$ Nimetatud liigisõnad on ilmselt sama päritolu kui ee süri sürje sürjä 'küngas', mis on tuntud kunagistel vadja aladel (Iis, Lüg ja Vai; VMS II: 471; EKNR: Sürgavere), is Kataajassürjä (mägi) (IMS: sürjä) ning sm syri syrjä 'mäeseljandik; mäehari' (SPK: Syri, Syrjäntaka). ${ }^{5}$ Muide enamik Eesti-Ingeri sürjä-osisega kohanimesid tähistab maaharimiseks kõlbmatut maad, sh Makaussürjä ja Taipaalan sürjä.

Primaarsetest soonimedest seostub osa mingi loodusliku objektiga nagu kivi või järv: $\mathrm{Li}^{\mathrm{ES}}$ Čivisoo 'Liivčülast Rüsümäe poole jääv soine ala, mille keskel on suur kivi' < čivi 'kivi'; J ${ }^{\mathrm{EK}} \mathrm{Lu}^{\mathrm{EK}}$ Järvisoo 'soo Jõgõperä kiriku taga', $\mathrm{J}^{\mathrm{A} 1} \mathrm{~J}^{\mathrm{A} 2} \mathrm{Li}^{\mathrm{ES}}$ Järvisoo 'soine ala kahe järve jäänukiga Ust-Luga jaama lähedal', $\mathrm{Ra}^{\mathrm{A} 1}$ Järvisoo $\sim$ Järvissoo 'soostunud ala Jõgõperä Herrvallas' < järvi 'järv'; Lu ${ }^{\mathrm{EK}}$ Silmäsoo < silmä 'siin ilmselt: laugas'. Li ${ }^{\mathrm{EK}}$ Polma-soo, $\mathrm{Lu}^{\mathrm{ES}}$ Polmasoo, $\mathrm{Li}^{\mathrm{A} 1}$ Polmassoo, $\mathrm{Lu}-\mathrm{Li}^{\mathrm{A} 1}$ Polmõsoo, $\mathrm{Li}^{\mathrm{A} 1} \mathrm{Li}^{\mathrm{A} 2}$ Polmõ-soo (kohanimekartoteegis soonimena puudub; vt ka 2.1 ja 5.1) võib täiendosana sisaldada seni talletamata maastikusõna *polma, vrd peamiselt Lääne-Eestis ja saartel, vähem keskmurdes tuntud põlmas : 'põlma, toponüümiosisena ka -põlm 'jäätmaa, mahajäetud põld; kõrge kuiv maa; põõsastesse kasvanud nõgu' (Kallasmaa 2003: 69, 112; VMS II: 275; kohanimena vt EKNR: Põlma). Esimese silbi $o$-line kuju viitab isuri (või ingerisoome) päritolule.

Sürgü esineb küll Kukkuzi sõnaraamatus, kuid puudub VKSis.

Lisanäiteid EKst: Vai Sürjesoo ja Sürja 'talu', sürjed 'kõrgemad kohad soos ja metsas', Jõh, Vai Möüräsüri : -sürje 'kõrgendik metsas', Jõh Süri 'heinamaa', Sürinõdu 'põllul kõrgendikule järgnev madalam koht' Süripääline 'kõrgem koht põllul', jt, Lüg Sürjõja nõmm. 
Kolmel juhul võib atribuudina arvesse tulla taimenimetus, ühel juhul, tõsi küll, taimede kasvukohana: $\mathrm{Ra}^{\mathrm{EM}}$ Maranikoo-soo $<*$ maranikko 'maranate kasvukoht' < maran; $\mathrm{Li}^{\mathrm{ES}}$ Paltikõõ soo 'soo Liivčüläst ida pool' < ?põltikaz 'nõges'; K-Sjögren Vöhkasuo < võhka 'soovõhk' (vrd is Vehkasoo 'võhka kasvatav soo Saarove külas'), kolmel juhul aga loomanimetus: $\mathrm{Lu}^{\mathrm{ES}}$ Čirppusoo (põld) < čirppu 'kirp' (registreeritud ainult põllunimes, vt 5.1); $\mathrm{M}^{\mathrm{EK}}$ Reposoo 'soo Mati küla lähedal'; $\mathrm{Ku}^{\mathrm{P}}$ Revoosoo < repo : revoo 'rebane'.

Asendi järgi eristuvad $\mathrm{Ra}^{\mathrm{EM}}$ Mäee-päälüsee-soo 'soo Jõgõperä mäel'

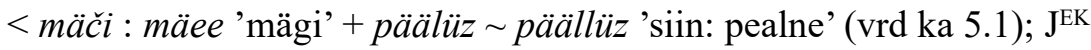
Peräsoo < perä 'siin: tagumine osa'; Lu ${ }^{\mathrm{EK}}$ Päällüssoo 'soo Võhkjärve mäel', Li ${ }^{E S}$ Päälüssoo 'soine ala Kivikalju mäe otsas'. Mõnd sood on peetud suureks: $(\mathrm{Ku})^{\mathrm{P}}$ Suurisoo, $\mathrm{Li}^{\mathrm{EK}}$ Suurisoo, $\mathrm{Lu}^{\mathrm{EK}}$ Suursoo 'soo Rüsümäe taga', Ra ${ }^{\mathrm{Al}}$ Suur-soo 'soo Halikkas', Vp ${ }^{\mathrm{B}}$ Suursoo 'soo Luuditsa ja Jõgõperä vahel' < suuri 'suur' (vrd is Suursoo (soo ja heinamaa), IMS: niittü, soo). Iseloomuliku kuju järgi on tuntud metafoorsed $\mathrm{M}^{\mathrm{EK}}$ Kaatsaa reisi 'kahe haruga soo; kahe haruga oja Mati lähedal' < kaatsad 'meeste linased püksid; aluspüksid' + reisi 'siin: (püksi)säär'.

Inimese nime või ameti järgi on nimetatud $\mathrm{Lu}^{\mathrm{EK}}$ Jürisoo, eestipärane Li ${ }^{\mathrm{ES}}$ Jürii turbasoo; $\mathrm{Ra}^{\mathrm{EK}}$ Poovari soo 'Halikkas paiknev soo', $\mathrm{Ra}^{\mathrm{E}}$ Povarin-soo; $\mathrm{Ra}^{\mathrm{EK}}$ Povarsoo 'koht Rajo küla lähistel, kuhu loomad aetakse lõunase lüpsi ajaks' < vn повар 'kokk'; Lu ${ }^{\mathrm{EK}} U l$ 'osoo 'mingi soo' $<$ ? naisenimi *Ul'o deminutiivsufiksiga -о (vn Уля $<$ Ульяна, vrd vdj Gar'o, Van'o jt; Saar 2016: 179) või ? mehenimi *Ul'o (vn Уля < Юлиан või Власий, vrd vdj Ulaska; Saar 2016: 175).

$\mathrm{M}^{\mathrm{EK}}$ Karjamakačči : Karjamakačii soo < karja 'kari' + makaučči 'magamiskoht' nimi näitab soo funktsiooni loomapidaja jaoks. Mingi riiu tõttu või tüliobjektina on nime saanud $\mathrm{Ku}^{\mathrm{P}}$ Riitasoo $\sim$ Riitsoo $<$ riita riito 'riid, tüli'. Soonimi I ${ }^{\mathrm{EK}}$ Karetii mätä 'soo, kuhu olevat maetud kuldne rootsi tõld', $\mathrm{I}^{\mathrm{A} 2}$ Karetii soo $\sim$ Karetii mätä $<$ karetti 'tõld' + mätä 'mädasoo?' seostub muistendiga Rootsi ajast. ${ }^{6}$ Üsna hiline on $\mathrm{Ra}^{\mathrm{A} 1}$ Samol'otti-soo 'soo, kuhu sõja ajal oli alla kukkunud lennuk'

Ičäpäivä keelejuht Aleksandr Andrejev on jutustanud: Vähä tagõpaza on Karetii mätä. Ain juõltii, što šveedaa kultõnõ karetti on mahaa tukattug. Tämä meni i eb pääznüd tagõpaa. I hukkazi mahaa karetii 'Vähe taamal on Tõllamäda. Ikka öeldi, et rootsi kuldtõld on maha maetud. Ta läks ja ei pääsenud kaugemale. Ja jättis tõlla maha' (Ariste 1977: 29). 
< vn самолёm 'lennuk'. Ainukese määrsõnalise atribuudiga kohanimi on $\mathrm{Ku}^{\mathrm{T}}$ Müllinsoo (heinamaa) < müllin 'pilla-palla' (vt 5.2). Lõpuni mõistetav pole $\mathrm{Lu}^{\mathrm{EK}}$ Kost'ja talittu 'mingi soo' $<$ mehenimi Kost'ja (vn Костя < Константин) + talittu (viimase sõna esinemise kohta vt 2.1 ja 4.3).

Soonimedes Kaatsaa reisi ja Kost'ja talittu liigisõna puudub. Ühe näite saab tuua, tõsi küll, eri murretest, täiendosa paralleelse nominatiivse ja genitiivse esinemise kohta: Reposoo ja $\mathrm{Ku}^{\mathrm{P}}$ Revoosoo. Atribuudi järgsilbi vokaal võib kaduda peale üldsõnade ka nimedes: Poovarisoo $\sim$ Povarsoo ja Riitasaari $\sim$ Riitsaari. Suhteliselt hilises nimes Povarin-soo on täiendosa genitiivi $n$-lõpp isuripärasus. Kohanimes $\mathrm{Ra}^{\mathrm{EM}}$ Takaa-daačoi soo esineb eessõna takaa 'taga' koos nimisõnaga daača 'suvila' (< vn) mitmuse partitiivis (vt ka 5.2).

Kukkuzist on kirja pandud soosaarte nimesid, millest osa viitab ilmselt seal kasvavale puuliigile, nagu $\mathrm{Ku}^{\mathrm{P}}$ Haapasaari < haapa 'haav'; $\mathrm{Ku}^{\mathrm{P}}$ Honkasaari $\sim$ Honkosaari $<$ honka 'hong, vana jäme mänd'; $\mathrm{Ku}^{\mathrm{P}}$ Koivusaari < koivu 'kask'. Üksikud ülejäänud nimed on teist päritolu: $\mathrm{Ku}^{\mathrm{P}}$ Lippert's'isaari < saksapärane perekonnanimi Lippertz?, ent vrd ka ee liperd 'lipakas' (VMS I: 443); $\mathrm{Ku}^{\mathrm{P}}$ Patasaari 'saar Riitsoos' $<$ pata '(savi- või metall)pott, pada'; $\mathrm{Ku}^{\mathrm{P}}$ Touksaari < touko $\sim$ tõuko 'tõug, tõuvili'. $\mathrm{Ku}^{\mathrm{P}}$ Romasaari atribuudi tähendus on tundmata. Kahes Kukkuzi sekundaarses soosaarenimes esineb eespool mainitud sürgü: $\mathrm{Ku}^{\mathrm{P}}$ Matosoo sürgü; $\mathrm{Ku}^{\mathrm{P}}$ Revoosoo sürgü.

Sekundaarseid soonimesid on teada vähe, sh $\mathrm{Ku}^{\mathrm{P}}$ Jefimpelloo soo $<$ mehenimi Jefim (< vn Edun) + pelto : pello 'põld' (vt ka 5.1); $\mathrm{Ku}^{\mathrm{T}}$ Jessinpellonsoo (vt 5.1 ja 5.2); $\mathrm{Ra}^{\mathrm{EM}}$ Tõrvaz-nõmmõ-soo (vt ka 5.2); $\mathrm{Ra}^{\mathrm{EM}}$ Valkõõ-nõmmõ-soo (sellenimelist nõmme pole registreeritud); $\mathrm{Ra}^{\mathrm{EK}}$ Vehkjärvee soo < vehkä võhka 'võhk (taim)' (vt 4.3). Kukkuzi nimedel esineb $n$-lõpuline genitiiv nagu isuri ja soome keeleski. Paar soonime seostub küla või selle osaga: $\mathrm{Ku}^{\mathrm{P}}$ Alapaa soo $<\mathrm{Ku}^{\mathrm{P}}$ Alappa 'Kukkuzi üks ots, mis asus Lauga jõe kaldal teisest külaotsast madalamal' < alapi : alapaa 'allpool asuv' (vrd J K alõpi : alõpaa 'madalam'); Lu${ }^{\mathrm{EK}}$ Kukkõzii soo.

\subsection{Mäenimed}

Mäenimesid on üsna palju. Nende determinant on enamasti mäči 'mägi', harva ka mätäz 'küngas', mille põhiliseks tähenduseks ongi 
'mätas'. Ühel juhul $\left(\mathrm{Lu}^{\mathrm{EK}}\right.$ Aarmakallaz = Aaromäči $)$ on liigisõnaks kallaz 'mägi; mäeveer', mis on arenenud esialgsest tähendusest 'kallas, rand' juba enne XV sajandit, vrd kreevini kalla orku 'mäejalam'. Kukkuzi nimes esineb erandlikult ka sürgü (vt ka 2.2).

Primaarsete mäenimede atribuudina võib esineda mõni looduslik üksikobjekt: $\left(\mathrm{Ko}^{\mathrm{E}}\right)$ Bugor-mäči < vn бугор 'küngas' (vrd vdj bugra 'küngas' < vn); $\mathrm{Ra}^{\mathrm{Al}}$ Lähtee mäči 'mägi allikaga Jõgõperä Kunigvallas' < lähe : lähtee 'läte, allikas'; J' ${ }^{\mathrm{EK}}$ Lähtepäälüz 'mägi Jõgõperält Narvuzi poole viiva tee ääres'< lähe : lähte + päälüz päällüz 'pealne; tipp'). Mäe nimi võib olla saadud ka puude kogumist.

Kivise koha järgi on oma nime pärinud $\mathrm{Li}^{\mathrm{A} 1}$ Čivikal'l'o 'mingi

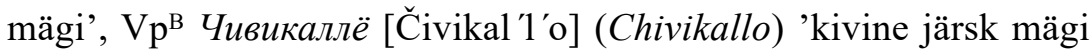
Limonadkal', Lu-Li ${ }^{\mathrm{Al}}$ Čivikal'l'o mäči, $\mathrm{Lu}^{\mathrm{ES}}$ Čivikal'l'oo mäči 'mägi Liivčülä-Jõgõperä tee ääres Liivčüläst minnes vasakut kätt', $\mathrm{Lu}^{\mathrm{A} 1}$ Čivikal'l'ooo mätäz < čivi 'kivi' + kal'l'io 'kivistik'. Puude või nende kogumi nimetusest on tuletatud (J) Aapamätäz (rahvalaulus) < aapa 'haab' (Ariste 1960: 52); M ${ }^{\mathrm{A2}} \mathrm{M}^{\mathrm{EK}}$ Pihkumäči 'mägi Mati küla lähedal' < pihku 'mänd'; $\mathrm{X}^{\mathrm{A} 2}$ Pihkuzikkomäči < pihkuzikko 'männik'. Loomariigi esindajate nimetustega seostuvad $(\mathrm{Ku})^{\mathrm{P}}$ Suteselkä (talletatud ainult metsanimes, vt 2.1)< susi : sutee 'hunt : huntide' + selkä : selää 'selg (tõenäoliselt mäeseljak)'; $\mathrm{Ja}^{\mathrm{T}}$ Varesmäči (vn гора Воронина), $\mathrm{Ja}^{\mathrm{EK}}$-Lensu Varõsmäči 'mägi Jarvigoiščülä lähedal', $\mathrm{Ja}^{\mathrm{A} 2}$ Varõzmäči $<$ varõz 'vares'.

Kiige asukohaga seondub Kõ ${ }^{\mathrm{EK}} L \tilde{o} \tilde{o} k k u-m a ̈ c ̌ i, \mathrm{M}^{\mathrm{A} 2}$ Lõõkkumäči < lõôkku 'siin: kiik'. Lu ${ }^{\mathrm{ES}}$ Mõizaamäči ('mägi Luuditsa ja Rüsümäe vahel' < mõiza 'mõis') paikneb endise mõisa lähedal. Kiriku või kunagise hiiekohaga on ühenduses $\mathrm{L}^{\mathrm{T}}$ Čerikkommäči, $\mathrm{Lu}^{\mathrm{EK}}$ Čerikkomäči 'koht Lempola külas', J' ${ }^{\mathrm{A} 2}$ Črikkomäči 'mägi Kattila ja Mati vahel', $\mathrm{K}^{\mathrm{EK}}$ Čerikommäči < čerikko 'kirik' (vrd is Kirgommägi Kirgomägi, ka IMS: mägi) ning $\mathrm{K}^{\mathrm{T}}$-Koski Idjeemäči $\sim$ Iisimäči, $\mathrm{M}^{\mathrm{A} 2} \mathrm{M}^{\mathrm{T}}$ Iisimäči <*iisi : *iijee 'hiis'; $\mathrm{Ma}^{\mathrm{K}}$ Iijee päällüz 'lehtpuudega mägi Mahu lähedal' $<$ päälüz päällüz 'pealne'. Pole teada, et Kattila Kullamäe ehk Kuldse mäega seonduks mõni lugu, ometi on lähtesõnad selge tähendusega: $\mathrm{M}^{\mathrm{EK}}$ Kultamäči 'mägi Kattila Suur-Õttsas'. $\mathrm{M}^{\mathrm{A} 1}$ Kulta-mäči' < kulta 'kuld'; PEK Kultanõ mäči 'mägi Kattila Suur-Õttsas' < kultanõ 'kuldne' (vrd E-Ing Kultmäki Kullakülas). Samuti pole andmeid, et (Lu) ${ }^{\mathrm{Al}}$ Rissimäči seostuks ristiga. Ühes rahvalaulus esineb (J) Pühämäči (Ariste 1960: 52) < pühä 'püha'. 
$\mathrm{Ra}^{\mathrm{EK}}$ Savipajamäči 'rinnatis maantee ääres Jõgõperä küla lähistel

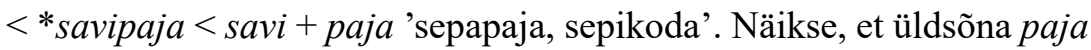
on tähistanud peale sepikoja ka teiste käsitööliste töökohta. Arheoloogiliselt pole tõestatud, et $(\mathrm{K})^{\mathrm{EK}}$ Lidnaamäči, $\mathrm{K}^{\mathrm{A} 2}$ Lidnamäči näitab muistse linnuse asukohta (*lidnaamäči $<$ lidna 'linn' + mäči). Küla järgi on nimetatud (Kõ) $)^{\mathrm{E}}$ Čülen-mäči; $\mathrm{M}^{\mathrm{EK}}$ Čülämäči $<$ čülä 'küla' ja Li ${ }^{\mathrm{ES}}$ Kattilaamäči 'mägi Kattila juures'. ${ }^{7}$

Tõenäoliselt kuju või muu omaduse järgi on tekkinud toponüümid $\mathrm{J}^{\mathrm{EK}} \mathrm{Li}^{\mathrm{EK}} \mathrm{Lu}^{\mathrm{EK}} \mathrm{Ra}^{\mathrm{EK}}$ Aaromäči 'kõrge küngas Jõgõperä lähedal', $\mathrm{J}^{\mathrm{A} 1}$ Aaromäči Aar-mäči 'mägi Jõgõperäl, kus asub kool', $\mathrm{Ra}^{\mathrm{A} 1}$ Aaro mäči 'mägi, millel asub Jõgõperä kirik', $\mathrm{Vp}^{\mathrm{B}}$ Аромаке (Aromake) [Aromake = Aaromäki] 'hiljem nimetatud Limonadka' [ebaõige samastus! Vt 4.6] $<$ aarto : aaroo 'sard'; Ku ${ }^{\mathrm{P}}$ Talkkunamäki 'mägi Vuhaoja (vt 4.5) ääres' $<$ talkkuna 'kama'. Öeldu näikse kehtivat ka Lu ${ }^{\mathrm{EK}}$ Pungõrmäči 'koht Kõrvõttulas Süväjärve läheduses' suhtes. Apellatiivi *pungõr pole vadja keeles registreeritud. Tõenäoliselt on tegu teatud konsonandijärge eviva deskriptiivsõnaga, vrd Ku pengere, is penger 'laugjas mäerinnak; veealuse laiu nõlv; söödilapp, põllupeenar', sm penger 'järsak; astang; vall', Ku pünkkä 'kõrgem koht jõe või mere põhjas', ee põngas 'põndak' (VMS II: 277), Rannapungerja (EKNR), antud juhul ehk *punk-tüve derivaadiga, vrd ka ee pungis.

Inimese eesnimest tuleneb $\mathrm{Lu}^{\mathrm{EM}}$ Pet'jo-mäči 'mägi, seal elanud asuniku nime järgi', Lu ${ }^{\mathrm{EK}}$ Pet'juи тӓс̌i, $\mathrm{Vp}^{\mathrm{B}}$ Петюмячи [Pet'umäči] 'osa Limonadkast' $<$ mehenimi Pet' $u$ deminutiivsufiksiga $-u$, $\operatorname{vrd} M a t ' u$, Tat'u jt (Saar 2016: 180; vn Петя < Пётр).

Algtähenduse poolest on mõneti ebakindel (Kõ ${ }^{\mathrm{EK}}$ Kaarlõmäči 'tõenäoliselt mägi Kõrvõttula lähedal', $(\mathrm{M})^{\mathrm{A} 1}(\mathrm{M})^{\mathrm{EK}}$ Kaarnaa mäči, Kõ ${ }^{\mathrm{A} 2}$ $\mathrm{M}^{\mathrm{A} 1}$ Kaarnaa mäči $\sim$ Kaarlõõmäči , sest vadja keelest pole leida sobivat lähtesõna, vaevalt, et lähtesõnaks on kaarna 'puust ujuk noodal' (vrd is kaarna 'kork; tohust ujuk; kuuse ja männikoor', sm kaarna). Seepärast võiks oletada seni registreerimata linnunimetust *kaarna 'kaaren, ronk'. Kas Kaarlõõ on tekkinud häälikumuutuse $r n>r l$ tagajärjel, vajaks eraldi uurimist.

Mati keelejuhi Petra Boranovi teatel: Med'd'ee čülä on varaapõõ ôllu Čülämäjell. Siäll on süed i ravvaa pazgad. Pajaa siha on siäll 'Meie küla on varem olnud Külamäel. Seal on sütt ja rauaräbu. Sepikoja koht on seal' (VE I: 169; Ariste 1977: 30). Seega kummagi mäe nimi on erinevat algupära. 
Mäe tähenduses on ühel juhul kasutatud $\mathrm{I}^{\mathrm{A} 1}\left(\mathrm{I}^{\mathrm{EK}}\right)$ Č̈̈läpää 'mägi Ičäpäiväst lääne pool', $\mathrm{I}^{\mathrm{A} 2}$ Čülä-pää) ka üldsõna pä̈ä, mispuhul areng on toimunud tõenäoliselt suunas 'elusolendi pea' $\rightarrow$ 'millegi tipp' $\rightarrow$ 'mäetipp' $\rightarrow$ 'mägi'. Apellatiiv veero $\sim$ veeru 'mäeveer, -rinnak' esineb ühes terminnimes ( $\mathrm{Ma}^{\mathrm{K}}$ Veero 'mingi mäerinnak').

Sekundaarsetest mäenimedest seostub osa veekogudega, nagu $\mathrm{P}^{\mathrm{EK}}$ Sumaa jõgõõ mäči (vt 4.4); $\mathrm{Lu}^{\mathrm{EK}}$ Vehkjärvee mäči, Lu-Li ${ }^{\mathrm{A} 1}$ Võhkajärvi mäči, Lu ${ }^{\mathrm{EK}}$ Võhkjärvee mätäz, Lu ${ }^{\mathrm{ES}}$ Võhkõõjärvii mäči 'mägi Võhkjärve ääres' (vt 4.3); Ku ${ }^{\mathrm{P}}$ Vuhaojaapäälüz (vt 4.5). Oru järgi on saanud nime PEK Orguo mäči (vt 2.4). Nimelise kiviga seondub (K) ${ }^{\mathrm{EK}}$ Rigovaa mäči (vt 2.6). Primaarsest mäenimest on tekkinud külanimi ja sellest omakorda uus mäenimi $\mathrm{Lu}^{\mathrm{ES}}$ Rizümäee mäči 'Rüsümäe küla lähedal'. Teisest kohanimest pärineb ka Lu ${ }^{\mathrm{EK}}$ Soikkolaa mäči.

Huvipakkuv on lisada, et vadjalastel on mäe- ja künkanimelisi külasid ja isegi üks linn: JEK Iivõni-mäči, Lu ${ }^{\mathrm{EK}}$ Ivana-mäči, 'Jaanilinn'; $\mathrm{I}^{\mathrm{EK}} \mathrm{Ma}^{\mathrm{K}} M \ddot{a} c \check{i} i$ 'Ičäpäivä'; (M) ${ }^{\mathrm{EK}}$ Mäčive 'Kattila' (vrd Mäčivee ranta 'mäginurk Kattilalt Kingissepani' (vrd is Mägi '[asula] Kabrio kandis', Mägövem poolez 'Kabrio kandis', Laanest 1997: 120-121); liite -ve -võ kohta vt Ariste 1967: 80); Lu ${ }^{\mathrm{EK}}$ Mättää čülä Mättüzii čülä 'Gorki küla Soikkola poolsaarel'; $\mathrm{Lu}^{\mathrm{EK}} \mathrm{Li}^{\mathrm{EK}} \mathrm{M}^{\mathrm{EK}}$ Risumäči 'Rüsümäe küla', $\mathrm{Lu}^{\mathrm{EK}}$ Rücümä $\sim$ Rüsümä $\sim$ Rüsümä čülä $\sim$ Rüsümä-čülä $\sim$ Rüsümäči $\sim$ Rüsümäe čülä; Li ${ }^{\mathrm{EK}}$-Lensu; Savimäči 'küla Soikkola poolsaarel', $\mathrm{Lu}^{\mathrm{EK}}$ Savimäči Savimäe (is Savimää 'küla Soikkola poolsaarel', vn Глинки).

Ebaselge päritoluga on $\mathrm{J}^{\mathrm{EK}}$-Tsvetkov Halik-mäči, sest atribuudi esialgne tähendus ja tähistav primaarobjekt pole teada, vrd (J ${ }^{\mathrm{EK}}$-Tsvetkov) Halikka '1. koht Rajo küla ümbruses; 2. Rajo küla läbiv oja, mis suubub Laugasse; 3. heinamaa, kust nimetatud oja saab alguse', (Ra) ${ }^{\mathrm{EK}}$ Halikaa oja, $\mathrm{J}^{\mathrm{A} 1} \mathrm{Ra}^{\mathrm{EK}}$ Halikaa niittü, $\mathrm{Ra}^{\mathrm{A} 1}$ Halikaaniittü 'heinamaa Jõgõperäl', $(\mathrm{J})^{\mathrm{Ts}}$ Halikkõ ['mingi koht, kus kasvab männimets, millest tehti maantee läbi' (Tsvetkov 1995: Halikkõ, hongõkõz, petäiin)]. Sõnaalguline $h$ näitab, et tegu pole vadja, vaid pigem soome või isuri nimega. Sellega saab kõrvutada soome vallanime Halikko ja vähem tõenäoliselt linnaosanime Halinen, mille lähteks peetakse kas saksa päritolu isikunime (vrd keskaegne Halike) või genuiinset antroponüümi *Halikka halu-tüvega 
'tahtma' (SPK). ${ }^{8}$ Vepslaste alalt on Süväri jõe äärest talletatud järvenimi Галик, mis tuletatakse samuti isikunimest, vrd Дениско Галиков ja Никитка Галиков Sortovala pogostis (Ruoppila 1943: 83). Leningradi oblasti atlase järgi paikneb mahajäetud paik *Halikk (yp[очuще] Галик) Narvuzi (vn Куземкино) lähedal, seega Rajost linnulennult nelja-viie kilomeetri kaugusel Lauga ääres (JZL: 16). Pole selge, kas see oli üksik majapidamine või väike külake. Selle oletatav asutaja või kunagine omanik võis olla Halikka, kelle nimi pärandus ka ojale, mis algab väidetavalt Rajo lähedalt ja suubub Laugasse, ning oja läheduses laiuvale heinamaale ja/või soole. Isuritelt on talletatud Halikka Haligam pooli 'külad Soikkolast Narva poole, Kõhtčizelt otse lõunasse'. Niiviisi näikse neil toponüüm olevat muutunud umbmääraseks laiema piirkonna nimeks. See tõendab, kuidas kohanime tekkekohast üha perifeersemalt paikneva paiga nime puhul muutub selle tähendus laiemat piirkonda haaravalt umbmäärasemaks. D. Tsvetkovi sedelkogus mitmes kohas leiduva Halikkõ on Jõgõperä sõnaraamatusse iseseisva märksõnana lisanud selle koostaja Johanna Laakso ning täpsustanud maakohta ilmselt isuri sõnaraamatust laenatud lausepoolega 'külad Soikkolast Narva poole'.

\subsection{Orunimed}

Kohanimekartoteegis on kirjas vaid kaks orunime: determinandita $\mathrm{I}^{\mathrm{A} 1} \mathrm{I}^{\mathrm{A} 2} \mathrm{I}^{\mathrm{EK}}$ Čülänaluz 'org Ičäpäiväst Kabrio poole' < čülä 'küla' + aluz 'siin: alus, alune' ja terminnimi $\mathrm{P}^{\mathrm{EK}}$ Orko 'org Pummala külas või selle lähistel' (vrd is $\operatorname{Orgo})$.

\subsection{Nõmmenimed}

Päris kindlaid nõmmenimesid pole talletatud, küll on aga aegade jooksul pandud kirja kolm nõmmi-determinandiga nime: $\mathrm{Vp}^{\mathrm{B}}$ Чивикономми [Čivikkonommi $=$ Čivikkonõmmi] 'Liivčüla-tagused heinamaad' < čivikko 'kivistik; kivine' (vrd ka Vai Kiviku (talu) < kivik

\footnotetext{
Päris võimatu pole ühendada vene eesnimede Фал ja Фалей (< Фалалей) hüpoteetilise deminutiivse läänemeresoome vastega *Hal-ikka. Oletuse tõenäosust vähendab oluliselt vastavuse vn $\phi \sim \operatorname{lms} h$ piirdumine teadaolevalt vaid ühe isuri nimega Нiil'o $<$ Филимон (Saar 2016: 168).
} 
'kivine koht', VMS I: 239; is Kivikko $\sim$ Kivikkoniittü, IMS: kivikko), identifitseerimata kohanimi $\mathrm{Ma}^{\mathrm{K}}$ Mäčevee nõmmi (vrd Mäčive 'Kattila', vt 2.3 ja 4.5) ning $\mathrm{Ra}^{\mathrm{EK}}$ Tõrvaznõmmi, ${ }^{\mathrm{EK}}$ Tõrvõz-nõmmi $\sim$ Tõrvõznõmme 'nõmm? Jõgõperä ja Narvuzi küla vahel' < tõrvaz 'tõrvas, vaigune puu'. Mainiksime siinkohal veel teadmata sisuga terminkohanime J Liivikko < liivikko 'liivik; metsasalu?'; viimane tähendus on kahtlemata sekundaarne, esialgne tähendus seondub sõnaga liiva 'liiv'.

\subsection{Kivinimed}

Vadja kivinimesid on talletatud vähe. Nende determinandiks on čivi Ku kivi. Enamasti on tegu primaarnimedega, millest osa seondub isikunimega. Nendest $\mathrm{K}^{\mathrm{EK}}$ Krigovaa čivi, $\mathrm{K}^{\mathrm{A} 1}$ Rikovaa čivi $\sim$ Riigova čivi 'kivi Savvokkala ja Lempola vahelises metsas' puhul jutustatakse lugu, milles olevat selle kivi juures saanud lihavõttemuna veeretamisel surma keegi Grigori ja kuhu olevat pärastpoole kogunetud rituaalide sooritamiseks. Näikse, et kivi nimi pole ühenduses eesnimega Grigori, sest teadaolevalt pole registreeritud eesnimeliidet $-v a$. Pigem on tegemist venepärase perekonnanimega Krigov, mille kandjaid elab veebi andmeil ka tänapäeval.

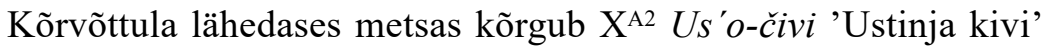
$<$ eesnimi $* U^{\prime}{ }^{\prime} o<$ naisenimi Ustinja (vrd vn $У_{c m} r<У_{c}$ стнья) jt. Rituaalidega liituvad ka X $\mathrm{X}^{\mathrm{A} 2}$ Iiliää čived 'kivid Pummalas, kus eeliapäeval ohverdati' (vt 2.1); $\mathrm{X}^{\mathrm{A} 2}$ Liuččivi 'kivi Ičäpäivä lähedal, millel teatud päevadel lasti rituaalset liugu' < liuku 'liug' (vrd liukumäči 'liumägi'); X ${ }^{\mathrm{A} 2}$ Čivirõukko 'kivihunnik Matis [ohvrikohana]' < rõukko '(ohvrikivi)hunnik'. Väljaspool usundisfärä olevaks kivinimeks on $\mathrm{Ku}^{\mathrm{E}}$ Lohkinain kivi< is lohkinain 'lõhkine' (vrd vdj lõhčinain). Jõe järgi on teiseselt saanud oma nime $\mathrm{Ku}^{\mathrm{P}}$ Rosonaa kivi' Rosona jõe alguses Lauga jõe lähedal asuv kivi' ${ }^{9}$

$9 \quad$ Ilmar Talve (1981: 1.2.1) mainis Kattila lähedases metsas asuvat ohvrikivi soomekeelse nimega Isokivi. Kas vadja nimi oli *Isočivi, pole teada. Vähemalt Luuditsas oli soome laensõna iso 'suur' tuntud (VKS). 


\section{Rannajooneobjektide nimed}

Vee ja maismaa piirile jäävate rannajooneobjektide nimede hulka kuuluvad randade, poolsaarte, neemede, madalike, saarte ja laidude nimed. Eriti madalike, saarte ja laidude nimesid võib peale vadja keele pärineda ka teistest läänemeresoome keeltest. Vadjalased - ja mitte ainult nemad - ei teinud alati selget vahet karide ja laidude ning puhuti isegi saarte ja madalike vahel. Seepärast on nende nimede liigitamine mõneti tinglik.

\subsection{Rannanimed}

Rannanimede liigisõnaks on ranta 'rand'. Tegu on sekundaarsete nimedega. Enamik mererandu, täpsemini Soome lahe randu on nimetatud küla või muu asula järgi: Lu-Li ${ }^{\mathrm{ES}}$ Hakajaa ranta 'mererand Kaipala rannast ida poole'; Lu-Li ${ }^{\mathrm{ES}}$ Kaipalaa ranta 'mererand Kurkola rannast ida poole'; Lu-Li ${ }^{\mathrm{ES}}$ Konnuu ranta 'mererand Hakajast ida poole'; $\mathrm{Lu}^{\mathrm{A} 1}$ Lu-Li ${ }^{\mathrm{ES}}$ Kurkulaa ranta 'mererand Kurkula küla all'; $\mathrm{Lu}^{\mathrm{ES}}$ Kõhčizõo ranta 'mererand Kõhtsõ küla all', $(\mathrm{Lu})^{\mathrm{EK}}$ Kõhtsõ ranta; $\mathrm{Lu}^{\mathrm{ES}}$ Liivčülää ranta 'mererand Liivčülä all'; $\mathrm{Lu}^{\mathrm{A} 1} \mathrm{Lu}^{\mathrm{ES}}$ Logaa ranta 'rannaosa Soikkola poolsaarel', Lu ${ }^{\mathrm{A} 1}$ Looranta; $\mathrm{Lu}^{\mathrm{EK}}$ Luutsaa Leesii ranta 'mererand Luuditsa all' < leesi 'leetseljak'; $\mathrm{Lu}^{\mathrm{A} 1} \mathrm{Lu}^{\mathrm{ES}} \mathrm{Lu}-\mathrm{Li}^{\mathrm{ES}}$ Luutsaa ranta 'mererand Luuditsa all'; Lu-Li ${ }^{\mathrm{ES}}$ Pakarii ranta 'Narva-Jõesuu mererand'; Lu-Li ${ }^{\mathrm{ES}}$ Pärispää ranta 'mererand Pärispää küla all', $\mathrm{Lu}^{\mathrm{Al}}$ Pärspää ranta; $\mathrm{Lu}-\mathrm{Li}{ }^{\mathrm{ES}}$ Ropsuu ranta 'mererand Kontu rannast ida poole'; $\mathrm{Lu}^{\mathrm{A} 1}$ Viibijää rant, $\mathrm{Lu}^{\mathrm{ES}}$ Viib'a a ranta 'mererand lääne pool Laugat'; $\mathrm{Lu}^{\mathrm{ES}}$ Viistinaa ranta 'rannaosa küla all Soikkolas', $\mathrm{Lu}^{\mathrm{Al}}$ Viistinaa ranta.

Soome lahe rannikuosa $\mathrm{Lu}^{\mathrm{ES}}$ Laukaa ranta 'mererand ida pool Lauga jõge', Lu ${ }^{\mathrm{A} 1}$ Laukaaranta on nimetatud merre suubuva jõe järgi. Leidub ka paar erinime, sh determinandita $\mathrm{Vp}^{\mathrm{B}}$ Грейви (Grejvi) 'Soome lahe kalda osa, Luuditsa jõest Lauga jõeni, mida on alati kasutatud heinamaana', $(\mathrm{Lu})^{\mathrm{A} 1}$ Greivi, $\mathrm{Ra}^{\mathrm{A} 1}$ Kreivi-ranta 'heinamaa Jõgõperäl' $<$ sm kreivi 'krahv' (rannaala kuuluvuse alusel?); Lu-Li ${ }^{\mathrm{ES}}$ Lutoo ranta 'mererand, [kuid pole selge, kas jääb] Vibijää rannast ida või lääne poole' $<$ ? is luиDo 'kari, rahu; [ilmselt ka] laid' (vrd vdj looto); Li ${ }^{\mathrm{Al}}$ Muussa $=$ Liivõčülä ranta, $\mathrm{Lu}^{\mathrm{ES}}$ Muuzõõ ranta 'väike mererannalõik Liivčülä all' (vt ka 2.1, 4.3, 4.4 ja 5.2). Metsa, järve, jõe, rannikuosa ja maanurga nime Muussa: Muusaa $\sim$ Muиzõõ puhul pole päris selge, mida 
ta esialgu tähendas ja millist objekti ta neist tähistas. ${ }^{10}$ Probleemi ei aita lahendada ka kunagisel vadjapäraste elanike alal Iisaku kandis asunud talu nimi Muusa (EK).

Oma nimi võis olla ka jõe, järve ja oja rannal: $\mathrm{Lu}^{\mathrm{ES}}$ Jõgõõ ranta 'Tõrvajõe kallas mõlemal pool jõge' < jõki : jõgõo 'jõgi : jõe' (siinpuhul Jõki terminnimena); $\mathrm{Ku}^{\mathrm{T}} J$ Järvenranta (põld) < järvi 'järv' (vt 5.2) ning $\mathrm{Ra}^{\mathrm{A} 1}$ Väärnõjaa ranta (vt ka Väärä-õja, 4.5). Kahe viimase toponüümi täiendosa sisaldab isuri- või soomepärast genitiivitunnust - $n$. Pole enam teada, kas kohanimi J $\mathrm{J}^{\mathrm{A} 1}$ Mitrofonaa ranta $(<$ mehenimi; vrd vn Митрофан) tähistab Soome lahe randa või Lauga jõe kallast.

\subsection{Poolsaare- ja neemenimed}

Vadja keeles on üldsõna neemi 'neem' küll olemas, kuid toponüümi determinandina kasutatakse seda tänini talletatud kohanimedes vaid ühel korral. Tavaliselt esinevad liigisõna funktsioonis apellatiivid nenä, nukka ja nurkka '(maa)nina, neem', samuti isuri keeles. Nina ja nurk, samuti pea on tavalised ka eesti keeles (Päll 2020: 299). Eri sõna poolsaare tähistamiseks puudub, seepärast nad ei eristu nime poolest väiksematest neemedest ja neemikutest. Algsem nimetus näikse olevat $p a ̈ a ̈$, vrd Pärnis-pää Pärspää nenä < pärnine pärnäne 'pärnane, [pärnadega]' + pää + nenä (vrd ee Pärispea < *Pärnispää < pärn, EKNR; vt ka Päll 2020: 242, 286); Kolgaapää nukka < kolkka: kolkaa 'nurk, [kõrvaline koht?]' + pää + nukka. Eesti keeles kasutatakse sõna poolsaar peamiselt kirjakeeles, rahvasuus on tuntud teised sõnad (vt Päll 2020: 299).

Primaarseid neemenimesid on vähe: $\mathrm{Ku}^{\mathrm{P}}$ Hijjee nukka $\sim$ Hijjeenukka 'neem Lauga jõe ja Kukkuzi järvest (vt 4.3 allmärkus) algava lisajõe vahel' <*hiisi 'hiis'; Ku ${ }^{\mathrm{P}}$ Kivinenä 'Lauga jõkke ulatuv neemeke' $<$ kivi; $\mathrm{Li}^{\mathrm{EK}} \mathrm{Lu}^{\mathrm{EK}}$ Muhuu nenä 'neem Kurkola poolsaarel'< is, sm muhku : muhun 'muhk, kühm', vrd sm muha $\sim$ muho $\sim$ muhu 'soine maa' (vrd ee Muhu, EKNR; sm Muhniemi, Muhos, SPK); I ${ }^{\mathrm{A} 2}$ Piččä neemi (põld, vt

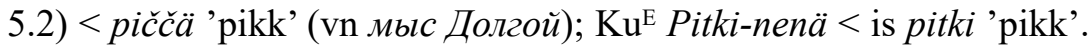
Kohanime $\mathrm{Ku}^{\mathrm{P}}$ Kuuzippaa nenä asukoht ja tähendus on tundmata. $\mathrm{Ku}^{\mathrm{P}}$

10 Huvitav teada, et Lõuna-Lätis Bauska kandis, kuhu olid sõjavangidena Bauska kindlust ehitama küüditatud kreevinite nime all tuntud vadjalased, voolab Mūsa jõgi. 
Laukaa nenä võib olla sama mis Kivinenä. Seega polnud genitiivne Muhuu algselt vadja lekseeme, vrd muhku : muhguu.

Talletatud neeme- ja poolsaarenimed on tekkelt peaasjalikult sekundaarsed: J' ${ }^{\mathrm{EK}}$ Kolkapää nenä, Lu ${ }^{\mathrm{EK}}$ Kolgaapää nukka 'Kolgapää neem' (мыс Колганпя); $\mathrm{J}^{\mathrm{Ts}}$ Kurkolaa nenä ['Kurgola neem'] (vn мыс Кургальский); Lu ${ }^{\mathrm{EK}}$ Pärspää пепӓ 'Pärspää neem', Lu Pärspää nukka 'Pärspää neem' (VKS), Lu ${ }^{\mathrm{EK}}$ Pärspää nurkk 'Pärspää neeme tipp', J' Pärnis-pää 'neem'; Lu ${ }^{\mathrm{EK}}$ Soikkola $\sim$ Soikkola nenä 'Soikkola poolsaar', $\mathrm{Lu}^{\mathrm{EK}}$ Soikkola nukka, Lu Soikkolaa nurkka 'Soikkola [poolsaare] nina' (vn Сойкинский полуостров; VKS). Neis peegeldub sageli varasem neemenimi pää. Sekundaarselt on Kukkuzi küla otsa järgi saanud nime $\mathrm{Ku}^{\mathrm{P}}$ Dubrovaa neeme (VKSis sõnakuju neeme puudub).

\subsection{Madalikunimed}

Meremadalikunimede liigisõnaks on matala nagu ka eesti kohanimedes madal (vt Päll 2020: 302), samuti is mataala (vrd ka deminutiivne terminnimi Madaloi 'Loankülä kalapüügikoht'). Nende algupära on kirev. Madalikunimedes kajastuvad värvus $\left(\mathrm{Lu}^{\mathrm{EK}}\right.$ Halli matala 'madalik Soome lahes Penisaare juures' < halli 'hall'), ilmakaar $\left(\mathrm{Lu}^{\mathrm{EK}}\right.$ Läns-looto 'Läänemadalik' < vdj länsi läns, is läns 'lääs' + looto 'laid'); linnunimetus ( $\mathrm{Lu}^{\mathrm{EK}}$ Varõhsi 'kaardil: Läns-looto madalik Soome lahes', Lu-Li ${ }^{\mathrm{A} 1}$ Varõsõõ matala, $\mathrm{Lu}^{\mathrm{ES}}$ Varõzõmatalad 'madalad Soikkola ja Seiskari saare vahel' < varõz 'vares', vrd is Variksemmataala 'Soikkola rannast umbes $15 \mathrm{~km}$ kaugusel asuv madalik, mis paikneb nn Välimadaloiz'); asend (Lu' ${ }^{\mathrm{ES}}$ Välimatala 'madalik Soikkola poolsaare ja Seiskari saare vahel', $\mathrm{Lu}-\mathrm{Li}^{\mathrm{A} 1}$ Välimatala, $\mathrm{Lu}^{\mathrm{A} 1}$ Välimatalad 'madalik poole maa peal Seiskari saarte ja Soikkola poolsaare vahel' $<$ väli 'vahe', vrd is Välimataalad 'Seiskari ja Soikkola vahel asuvad madalikud, kus kalastati'); rannik ( $\mathrm{Lu}^{\mathrm{ES}}$ Rantamatala 'madal meres Luuditsa ja Liivčülä vahel, 500 m kaugusel rannast', Lu-Li ${ }^{\mathrm{Al}}$ Rantamatala $<$ ranta 'rand'); naisenimi ( $\mathrm{Lu}-\mathrm{Li}^{\mathrm{A} 1} \mathrm{Lu}-\mathrm{Li}^{\mathrm{ES}}$ Marii matala 'madalik Mari laiu lähedal', vrd is Mari $\sim$ Marimmataala $\sim$ Marim mataalad 'Lauga jõe suudmest umbes $4 \mathrm{~km}$ kaugusel laiuv madalik' (ka IMS: mataala $<$ eesnimi Mari); küla $\left(\mathrm{Lu}^{\mathrm{Al}}\right.$ Viistinaa matalad $)$.

Omapärane madalikunimi on $\mathrm{Lu}^{\mathrm{EK}}$ Reimasaari 'madalik Soome lahes'< reima 'madalik' + saari (vn остров Pемисаap; vt ka 3.4), milles väljendub ilmekalt ebaselge piir madaliku ja saare vahel. Toponüümi 
$\mathrm{Lu}^{\mathrm{ES}}$ Mohnii matalad 'madalikud Seiskari saare lähedal Soome vetes' ja is Mohnim mataala (ka IMS: mataala) päritolu on ebaselge nagu ka Eesti vetes asuva Mohni saare nimi (vt EKNR). Jõemadalikest on talletatud üksnes $\mathrm{Ku}^{\mathrm{P}}$ Sepää mätäz 'madal koht Lauga jões' < seppä 'sepp' + mätäz 'mätas; küngas'.

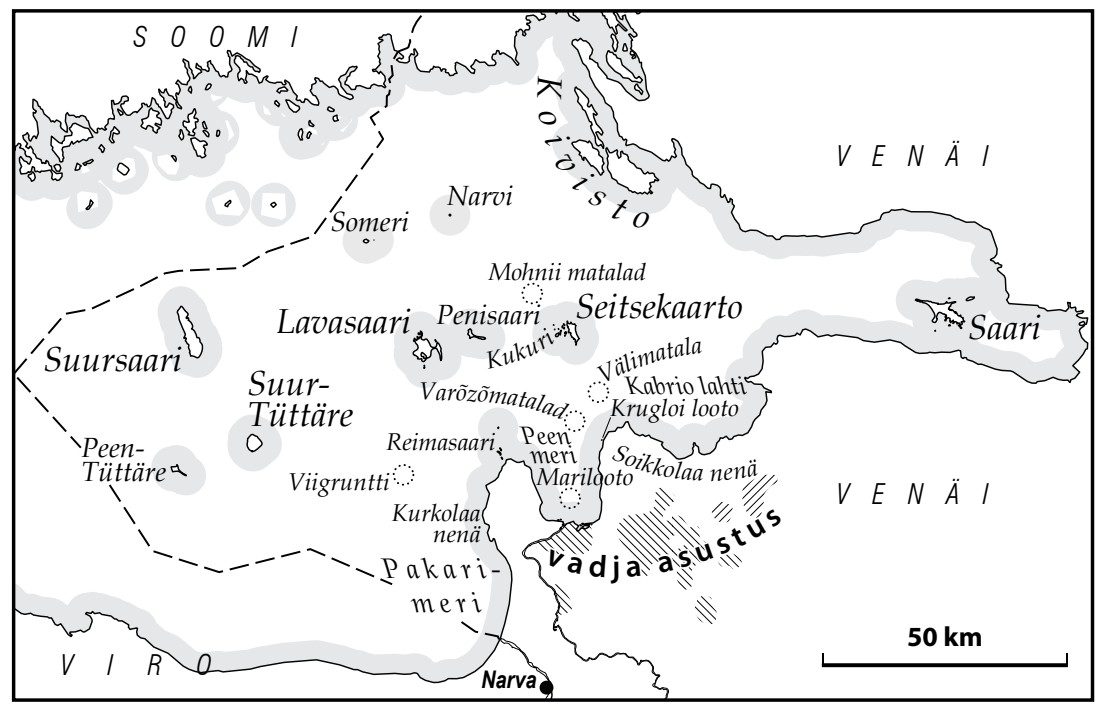

Joonis 2. Soome lahe idaosa vadja nimedega. Kaardi autor on Raivo Aunap.

\subsection{Saarenimed}

Vete poolt ümbritsetud saarte nimede determinandiks on saari. ${ }^{11}$ Erinevalt eesti keelest (vt Päll 2020: 300) ei nimetata vadja keeles saari laidudeks. Saarenimede põhimassi moodustavad Soome lahe saarte nimed, mis on vadja keelde tulnud ilmselt mitmest keelest, mistõttu nende etümoloogial ja tähendusrühmade moodustamisel siinkohal ei peatuta. Üldiselt kajastub saarenimedes puudekogum, suurus, külanimi jm.

11 Sama põhisõnaga on ka metsa- ja soosaarte nimed (vt 2.1. ja 2.2). Erandlikult on tögamisel Liivčülä külaotsi nimetatud saarteks: Lu-Li ${ }^{\mathrm{ES}}$ Katiisaari < katti : katii 'kass : kassi' ja Lu-Li ${ }^{\mathrm{ES}}$ Konnaasaari < konna 'konn'. 
Läänemere saartest on Eesti alalt talletatud kahe suurima saare nimi: $\mathrm{Lu}^{\mathrm{EK}}$ Hiitasaari 'Hiiumaa', Lu ${ }^{\mathrm{EK}}$ Iiumaa 'Hiiumaa'; J ${ }^{\mathrm{EK}} \mathrm{Lu}^{\mathrm{EK}}$ Saarõmaa 'Saaremaa'; viimane pärineb, tõsi küll, rahvalaulust: saijõd on tootu Saarõmaaltõ 'saiad on toodud Saaremaalt' (vrd is Saaremmaa 'Seiskari', Saaremmaat 'Soomelahe saared'), ${ }^{12}$ väikesaartest üksnes $\mathrm{Lu}^{\mathrm{EK}}$ Suuroppi 'Suurupi'. $\mathrm{K}^{\mathrm{T}}$ Karussaare (heinamaa, vt 5.2; e-lõpp võib olla talletaja eestipärasus) ja $(\mathrm{Ku})^{\mathrm{P}}$ Karuusaari seonduvad loomanimetusega karu. $\mathrm{Ku}^{\mathrm{P}}$ Terešksaari on ühenduses mehenimega Tereška $<$ vn Терентий (vrd vdj Teroška, se Teresk; Saar 2016: 172).

Vadjalastele olid tuntud järgmised Soome lahe saared ja saarestikud (vt joonis 2): $\mathrm{Ra}^{\mathrm{EK}}$ Koivisto, $\mathrm{J}^{\mathrm{EK}}$ Koivistu, $\mathrm{Ra}^{\mathrm{EK}}$ Koivistoo saari 'Koivisto saar [õigemini 'saared Karjala kannasel paikneva Primorski linna lähedal'; vn Березовые острова; rts Björkö]', vrd is Koivisson teе 'mingi Soome lahe väil Soikkolast vaadates'; $\mathrm{J}^{\mathrm{EK}} \mathrm{Li}^{\mathrm{EK}}$ Kukuri 'väike saar Seiskari juures' (vrd sm Kukkouri $\sim$ Koukouri; Iisaku Kukkuri (talu)); ${ }^{13}$ $\mathrm{X}^{\mathrm{A} 2}$ Laugassaari, Lu-Li ${ }^{\mathrm{ES}}$ Lavaasaari, ${ }^{\mathrm{EK}} \mathrm{Li}^{\mathrm{EK}} \mathrm{Lu}^{\mathrm{EK}}$ Lavasaari, ${ }^{\mathrm{Ts}}$ Lava saari Lava-saari, $\mathrm{Lu}^{\mathrm{A} 1}$ Lavassaari (ee Lavassaar, sm Lavansaari, is Lauvassaari (IMS: Lauvaz, vn Moщный, rts Lövskär); (Lu) ${ }^{\mathrm{A} 1}$ Luutsaa saari; $\mathrm{Lu}^{\mathrm{EK}}$ Narvi Narvisaari 'saar Soome lahes', $\mathrm{Lu}^{\mathrm{Al}}$ Narvi Narvisaari (vn Hepвa); (Lu) ${ }^{\mathrm{A} 1} \mathrm{Lu}^{\mathrm{EK}}$ Peni, ${ }^{\mathrm{EK}} \mathrm{Li}^{\mathrm{EK}} \mathrm{Lu}^{\mathrm{EK}} \mathrm{Lu}^{\mathrm{L}} \mathrm{Li}^{\mathrm{ES}}(\mathrm{Ra})^{\mathrm{A} 1}$ Penisaari 'saareke Seiskari saare lähedal' (is Peni; vn Мальй, varem Пенисаари; rts Peni-Ön Penisari); Lu ${ }^{\mathrm{EK}}$ Reimasaari 'madalik Soome lahes' < reima 'madalik' (saarenimena pole talletatud, vt 3.3); vrd is Reimi $\sim$ Reimisaari 'saar Kurgola poolsaare lähedal' (ka IMS: saari; vn Ремисаap, rts Ramö); $\mathrm{X}^{\mathrm{A} 2}$ Saari 'Kotlin' (vn Котлин), $\mathrm{M}^{\mathrm{K}}$ Saarõ, ka is Saari 'Kroonlinn [Kotlinil]' (IMS: saari); Lu ${ }^{\mathrm{EK}}$-Lensu Seiskaru 'Seiskari saar Soome lahes', Lu-Li ${ }^{\mathrm{EM}}$ Seitse-kaari, Lu ${ }^{\mathrm{EK}}$ Seitsekaaro, Lu ${ }^{\mathrm{EK}}$ Seitsekaarto, Lu-Li ${ }^{\mathrm{ES}}$ Seitsekaarto 'Seiskari saar', Lu ${ }^{\mathrm{EK}}$-Lensu Seitsekaartu,

12 Seda, et vadja näites kajastub meie Saaremaa, näikse osutavat sama rahvalaulu paralleelvärss: Viinad on tootu Viromaaltõ 'Viinad on toodud Eestimaalt' (Ariste 1960: 60). Ent päris kindel ei saa olla, vrd teises rahvalaulus tuõ siä, uni, ulkomaalt, / Saarõmaalt, Savvumaalt 'tule sa, uni, kaugelt maalt, Saaremaalt, Savomaalt' või kokki oli tootu Koivisoossa / a kokii poik oli tootu Saaremmaalta 'Kokk oli toodud Koivisoost, aga kokapoeg oli toodud Saaremaalt' (Ariste 1986: 10, 46). Siinkirjutaja meelest peaks keelejuhi Koivisoossa olla Koivisto : Koivistoo vadjapärane moonutus, mis tähistab tegelikult Soome lahes asuvat Koivisto saarestikku või mõnd muud Koivistot (vt ka 3.4). Seda on ilmselt põhjustanud isuri keele käänamisele iseloomuliku noomeniliite vaheldus -sto- : -sso-, vrd Koivisson tee (IMS: Koivisto).

13 Kukouri on kindlussaar Soomes Kotka linnas. 
$\mathrm{Li}^{\mathrm{EK}}$ Seitsikaaro, Lu ${ }^{\mathrm{EK}}$ Seitskaaro $\sim$ Seitskaaru $\sim$ Seitskaro, $\mathrm{J}^{\mathrm{Ts}}$ Seitts kaarto, Lu ${ }^{\mathrm{A} 1}$ Seitskaarto, J ${ }^{\mathrm{EK}}$ Seitskar $\sim$ Seiskar, J ${ }^{\mathrm{EK}}$ Seitsäkaarto $\sim$ Seitskaarto, Lu ${ }^{\mathrm{A} 1}$ Seitskaarõd (is Seitsekaardo $\sim$ Seitskaarto, vn Сескар; rts Seitskär); Lu ${ }^{\mathrm{Al}}$ Someri 'saar [Soome lahe idaosas $25 \mathrm{~km}$ kaugusel Soome mandriosast]' (sm Someri, rts Sотmarö vn Остров Маяк, varem Соммерс; vrd is Someroi (küla), Sommeered 'väljak Viistinäs', Sommeerimägi 'mägi Loanküläs', põllunimed Üläsomerit, Alasomerit $<$ somer : sommeerin 'sõmerliiv'); $\mathrm{J}^{\mathrm{EK}} \mathrm{Lu}^{\mathrm{EK}}$ Suursaari 'Suursaar' (is Suursaari, vn Гогланд; rts Hogland, varem Högland); J's Tüttersaari, $\mathrm{Lu}^{\mathrm{EK}}$ Tüttäre 'Tütarsaar', $\mathrm{J}^{\mathrm{EK}} \mathrm{Li}^{\mathrm{EK}}$ Tüttärsaari Tütärsaari 'Tütarsaar Soome lahes', vrd is Tüttersaari, vn Tютерс; Lu ${ }^{\mathrm{EK}}$ Peen Tüttäre ['Väike Tütarsaar'] (vn Mалый Tromepc; rts Lilla Tyterskär); Lu ${ }^{\mathrm{EK}}$ Suur Tüttäre ['Suur Tütarsaar'] (vn Большой Tютерс, rts (Stora) Tyterskär).

Vdj Laugassaari ja sellele vastav isuri toponüüm näikse olevat seostunud Lauga jõe nimega (vt 4.4.). Saari kohta vt Ernits 2020. Seiskari saare vadja nimekujude lõpuosa varieerumine on tingitud ilmselt sellest, et laeva- ja muude kaarte tähistamiseks olid kasutusel võrdväärsed teisendid kaari $\sim$ kaarto $\sim$ kaarõ. Seega on vadjalased tõlgendanud saare nimeks 'seitse kaart'. Kirjasõnas võib leida vähemalt kaht seisukohta: ühe järgi pärineb toponüüm soome sõnadest seitsen 'seitse' ja kari 'kari, madalik', teine oletus toetub rootsi keelele, lähtudes apellatiividest sjö 'meri' ja skär 'skäär, laid' (OS).

Neist determinandita saarenimed on Koivisto, Kukuri, Narvi, Seitsekaarto, Someri ning Tüttäre, sh Peen Tüttäre ja Suur Tüttäre. Silmatorkav on Seiskari nimevariantide rohkus. Terminnimede hulka kuulub Saari.

\subsection{Laiunimed}

Laiunimede tavaliseks determinandiks on looto (is loopo), mille variantideks on luto, luuta ja luuto. Vähemalt viimane sõna on isuripärane, vrd is lииро ja vene laensõnana луда. Huvitav on siinkohal märkida, et eesti keeles on lood : loo saarekese ja laiu tähenduses tuntud Kuusalu murrakus ning kunagise vadja mõjuga aladel, nimelt Torma ja Kodavere kihelkonnas, kohanimena peale Kuusalu vähemalt ka ViruNigulas (Raudlood; EMS V: 394; Päll 2020: 300). ${ }^{14}$ Vaid ühel juhul

14 Sõna puudub VMS-s. 
on vadja keelejuht kasutanud liigisõna kehvel 'kehvel, leetseljak, meremadalik', mis esineb samal kujul ka eesti ja isuri keeles, vrd samuti krj kehveli 'liivamadalik' (EES, Nissilä 1975: 32). Laiunimede hulgas leidub nii vadja ja isuri kui ka soome ja vene sõnu.

Looduskogumi või omaduse järgi on saanud nime $\mathrm{Lu}^{\mathrm{ES}}$ Čivilooto 'Mari laiu kivine osa'; $\mathrm{Lu}^{\mathrm{A} 1} \mathrm{Lu}-\mathrm{Li}^{\mathrm{A} 1}$ Čivisaari; $\mathrm{Li}^{\mathrm{A} 1}$ Halli looto, $\mathrm{Lu}-\mathrm{Li}^{\mathrm{ES}}$ Hallii looto, $\mathrm{Lu}^{\mathrm{ES}}$ Halliluutaa looto (sm Halliluoto 'laid Helsingist lõuna poole' < halli 'hall'; $\mathrm{Ku}^{\mathrm{P}}$ Kivilooto 'laid Mari all' $<\mathrm{Ku}$, is kivi (vrd is Kiviluudo); $\mathrm{Lu}^{\mathrm{A} 1} \mathrm{Lu}^{\mathrm{ES}}$ Krugloi looto 'laid meres Soikkola küla all' < vn кругльий 'ümmargune' (vn Круглолода); $\mathrm{Lu}^{\mathrm{EK}} \mathrm{Lu}^{\mathrm{ES}}$ Liivvaalooto 'Mari laiu liivane osa, nime üleskirjutamise ajal madalik, sest liiv oli veetud Peterburi'; $\mathrm{Lu}^{\mathrm{A} 1} \mathrm{Lu}^{\mathrm{EK}} \mathrm{Lu}-\mathrm{Li}^{\mathrm{A} 1}$ Liivasaari 'väidetavasti Marilaiu osa'< liviva 'liiv'; $\mathrm{Ku}^{\mathrm{E}}$ Mussa-saari 'pole päris kindel, et laid'; $\mathrm{Lu}^{\mathrm{ES}} \mathrm{Lu}^{\mathrm{Al}}$ Pikkarain looto 'kahe-kolme kiviga laiuke Mari laiu lähedal' < pikkarain pikkarainõ 'väike'. Tõenäoliselt kalade kudemispaiga järgi on saanud nime Lu-Li ${ }^{\mathrm{ES}}$ Kutuulooto, $\mathrm{Li}^{\mathrm{A} 1}$ Kutu-looto.

Kireva kirjapildiga on Mari-täiendosaga nimed: $\mathrm{Lu}^{\mathrm{EK}}$ Mari, $\mathrm{Lu}^{\mathrm{A1}}$ Mari $\sim$ Mari-luuta, $\mathrm{Lu}^{\mathrm{EK}}$ Marikehveli 'Mari kari', $\mathrm{Lu}^{\mathrm{A} 1} \mathrm{Lu}^{\mathrm{EK}}$ Mari looto, $\mathrm{Li}^{\mathrm{EK}} \mathrm{Lu}^{\mathrm{EK}} \mathrm{Lu}-\mathrm{Li}^{\mathrm{A} 1}$ Marilooto, $\mathrm{Lu}^{\mathrm{EK}}$ Mari-looto $\sim$ Mari-luto $\sim$ Mariluuta, $\mathrm{Lu}^{\mathrm{A} 1}$ Mari-looto, $\mathrm{X}^{\mathrm{A} 2}$ Mari-luuto, $\mathrm{Ku}^{\mathrm{P}}$ Marii kehveli, $\mathrm{Li}^{\mathrm{A} 1}$ $\mathrm{Lu}^{\mathrm{ES}}$ Marii looto 'laid meres Lauga suudme vastas ligikaudu $6 \mathrm{~km}$ kaugusel rannast', $\mathrm{Li}^{\mathrm{EK}} \mathrm{Lu}^{\mathrm{EK}}$ Marisaari 'saar Lauga lahes Pärspää ja Soikkola vahel', vrd ka is Marillooto $~ M a r i n ~ l u u d o ~ ' l a i d ~ L a u k a a n s u u$ küla lähedal', IMS: looto, Mari).

Külanimega on sekundaarselt ühenduses $\mathrm{Lu}^{\mathrm{ES}}$ Kolkaapää looto 'üks Välimadala laide'; Lu ${ }^{\mathrm{ES}}$ Kurkulaa looto 'laid meres Kurkula küla all'; $\mathrm{Lu}^{\mathrm{ES}}$ Kõhtsõõ looto 'laid meres Luuditsa ja Kõhtsõ vahel'; $\mathrm{Lu}^{\mathrm{EK}} \mathrm{Lu}^{\mathrm{ES}}$ Pärispää looto 'väike madalik Pärispää küla all'; $\mathrm{Lu}^{\mathrm{ES}}$ Viistinaa looto 'üks Välimadala laide'. Võõrast algupära on $\mathrm{Lu}^{\mathrm{A} 1} \mathrm{Lu}^{\mathrm{ES}}$ Demahtõistõi looto 'laid Seiskari saare ja Soikkola poolsaare vahel' ( $<$ vn?) ja JEK $\mathrm{Lu}^{\mathrm{EK}}$ Viigrunni, Li ${ }^{\mathrm{EK}}$ Viigruntti 'Vigrundi rahu Soome lahes, [täpsemini madalik Narva lahes]', Lu ${ }^{\mathrm{A} 1}$ Viigruntti (< rts grund 'kari, madalik'; rts Vigrund, vn Вигрунд). Laiunimedes Mari ja Viigrunni $\sim$ Viigruntti determinant puudub. 


\section{Veekogunimed}

Veekogunimede alla on paigutatud merelahtede, kalapüügikohtade, järvede, jõgede, ojade, allikate ja tiikide nimed.

\subsection{Lahenimed}

Vadjalastel pole Läänemere kohta oma nime, vaid see on laenatud vene keelest: $\mathrm{Li}^{\mathrm{EK}} \mathrm{Lu}^{\mathrm{EK}}$ Baltikka-meri, $\mathrm{M}^{\mathrm{EK}}$ Baltii-skoi meri, $\mathrm{Ja}^{\mathrm{EK}}$-Lensu Balttia meri, Li ${ }^{\mathrm{EK}}$ Balttimeri (vn Балтийское море). Vaipoole vadjalaste külad paiknevad Soome lahe ääres, kuid ka selle nime J ${ }^{\mathrm{Ts}}$ Soomо̃õ meri 'Soome laht' (is Soomel lahti, vn Финский залив) kasutamise järele pole nähtavasti olnud erilist vajadust. Vaipoole rahvas, kes elatusid peamiselt kalapüügist, tundsid üsna hästi Soome lahe abajaid ja lahtesid. Kuigi vadja keeles on sõna lahti 'laht' olemas, toponüümikas seda ei kohta. Selle asemel kasutatakse determinandina sõna meri, ühel juhul ka vene laensõna buhti : buhii 'väike laht, abajas' (vrd vn бyxma).

Esmased kohanimed on asendi järgi nimetatud $\mathrm{Lu}^{\mathrm{A} 1}$ Alameri 'Kurgola lahe maapoolne osa', $\mathrm{Lu}^{\mathrm{ES}}$ Alameri 'Kurgola lahe osa' $<$ ala 'ala-, alumine', vrd is alameri '[mereosa, mis] algab umbes $7 \mathrm{~km}$ kaugusel Kurgola poolsaare rannikust'; Lu ${ }^{\mathrm{Al}}$ Ülämeri 'Kurgola lahe avamerepoolne osa', Lu ${ }^{\mathrm{ES}}$ Ülämeri 'mereosa Kurkola poolsaare ümber' < ülä 'üla-, ülemine', vrd is Kurkulan Ülämeri Ülämeri '[mereosa, mis] algab ligikaudu 14-15 km kaugusel Kurgola poolsaare rannikust'. Mõlemat kasutatakse ka apellatiivina. Primaarsete toponüümide hulka kuulub ka omadussõnalise täiendosaga Peen meri 'Lauga laht' (VKS) $<$ peen peeni 'väike; vaikne' .

Ülejäänud lahenimed kuuluvad sekundaarsete kilda. Küla- või linnanime alusel (osal juhtudel ei saa välistada lähtumist poolsaarenimest) on tekkinud $\mathrm{Lu}^{\mathrm{EK}}$ Kurkola meri, Lu ${ }^{\mathrm{A} 1}$ Kurkolaa meri $\sim$ Kurgulaa meri, Lu-Li ${ }^{\mathrm{ES}}$ Kurkula meri 'meri Kurgola küla all Lauga suudmest lääne poole'; (M ${ }^{\mathrm{EK}}$-Kettunen Kõhčizee buhti 'Koskolovo laht'; $\mathrm{X}^{\mathrm{A} 2}$ Narva meri 'Narva laht'; Ra ${ }^{\mathrm{EK}}$ Pakarii meri 'Narva laht', $\mathrm{Ra}^{\mathrm{A} 1}$ Pakarimeri (Narva-Jõesuu nime Pakari järgi); Lu ${ }^{\mathrm{ES}}$ Pärispää meri 'mereosa Pärispää küla all', Lu ${ }^{\mathrm{ES}}$ Pärispää noottõõ meri < noottõ nootta 'noot (kalapüügivahend)'; $\mathrm{M}^{\mathrm{EK}}$ Soikkolaa meri 'Soome laht Soikkola poolsaare kohal'. 
Osa lahenimesid on tekkinud neis asuva(te) saar(t)e või laiu järgi (vt 3.4): $\mathrm{Lu}^{\mathrm{ES}}$ Lavaasaarõõ meri 'mereosa Lavasaare ümber'; Lu-Li ${ }^{\mathrm{ES}}$ Saarõõmeri 'mereosa Seiskari saare ümber'; Lu-Li ${ }^{\mathrm{Al}}$ Saarõmeri 'mereosa Seiskari saarte ümbruses'; Lu ${ }^{\mathrm{ES}}$ Seitskaaroo meri 'mereosa Seiskari saare ümber'; Lu ${ }^{\mathrm{ES}}$ Tüttärsaarõõ meri; Lu ${ }^{\mathrm{A} 1}$ Viigruntti-meri.

Paaril juhul kajastab lahenimi sinna suubuva jõe nime: $\mathrm{Lu}^{\mathrm{ES}} \mathrm{Kabr}{ }^{\prime}$ oo ustii meri 'mereosa Kabrio lahes' < *usti 'suue' < vn ycmbe; $\mathrm{Li}^{\mathrm{iEK}}$ Laukaa meri 'Lauga laht' (vn Лужская губа), Lu ${ }^{\mathrm{ES}}$ Laukaa ustii meri 'mereosa Lauga suudme vastas'. Siia võib paigutada ka kohanime J1 Li1 Lu1 Meresuu 'Lauga laht'. Sama nime kandis ka Ust-Luga asula

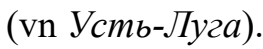

\subsection{Kalapüügikohtade nimed}

Vadja polüsemantiline sõna apaja 'abajas (madal märg koht; mudane, umbekasvanud jõgi, oja või kraav; lomp); abajas, väike merelaht; kalapüügikoht, loomusekoht (meremadalal)' on viimati mainitud tähenduses saanud kalapüügikohta tähistavaks determinandiks. Huvitav on siinpuhul märkida, et käsitletav germaani laensõna, mille esialgne tähendus oli mingi madala veekogu osa (jõekäär, merelaheke), säilitas selle tähenduse vaid eesti ja vepsa keeles, kuid ülejäänud läänemeresoome keeltes, ka osaliselt vepsa keeles hakati niiviisi tähistama kalapüügikohta (vt EES: 42). Lauga jõe loomuste puhul on kasutatud liigisõna vesi.

Tundub, et apaja-sõna peitub ka käesoleval sajandil talletatud moonutises $\mathrm{Vp}^{\mathrm{B}}$ Вадья опая [= Vad'ja opaja] 'koht, kuhu maeti hobuseid', vrd ka is apaaja. Pole võimatu, et korjuste matmise koha nimi seondub ehk paiknemise järgi abajanimega $\mathrm{Li}^{\mathrm{EK}}$ Võd'd'apaija, $\mathrm{Li}^{\mathrm{A} 1}$ Võd'd'e-apaja, Lu ${ }^{\mathrm{A} 1}$ Võd'd'a a apaja, mis on kirja pandud üksnes metsanimena (vt 2.1). Toponüümi täiendosa sobib häälikuliselt ühte apellatiiviga võd'd'õ : võitõ̃ $\sim$ võitõmõo 'võie, määre', kuid semantiliselt on seda raske põhjendada. Kindlam on uuritavat vadja toponüümi kõrvutada Pärnumaa külanimega Võiera, mispuhul peetakse algselt verelõpulise toponüümi lähteks muistset isikunime, vrd ee Wege [võie?] ${ }^{15}$ (EKNR: Võiera; Stoebke 1964: 74).

15 Muuseas oleks huvipakkuv teada, kas isikunime ja sellest tuletatud toponüümi moodustamisel on kasutatud sama apellatiivi nii nõrga- kui ka tugevaastmelist vormi, vrd ee 'Võide (küla) ja 1341, 1342 Woyde (isikunimi) (EKNR: Võide; Stoebke 1964: 81). 
Ida-Virumaa külanimega Võide, mida seostatakse muistse isikunimega (vt EKNR; vrd 1341, 1342 Woyde; Stoebke 1964: 81). Ent kas muistne isikunimi on abajanimes nii kaua püsinud? Veelgi vähem tõenäoline on oletada toponüümi kujul *Vad'd'a apaja 'Vadja abaja'.

Omapärane loomusekohanimi on $\mathrm{Lu}^{\mathrm{ES}}$ Peniauta 'kalastamiskoht Soome lahes Lavassaare ja Seiskari vahel' < peni 'peni, koer' + auta 'auk, urg; hauakoht jões või meres; (surnu)haud' (vrd is hauda 'ka: merepõhjas olev piklik süvend', Penih havval (käändes)); siinkirjutajale pole teada, kas see seondub asendi järgi Penisaarega. Kahe Lauga jõe kalapüügi kohanime liigisõnaks on vesi: $\mathrm{Ku}^{\mathrm{P}}$ Alavesi 'kalapüügikoht Lauga jõel' < ala + vesi; $\mathrm{Ku}^{\mathrm{P}}$ Sutelaa vesi 'kalapüügikoht Lauga jõel'. Viimane on nimetatud samanimelise küla järgi (vn Волково). Ühe jõeloomusekoha nimeks on determinandita $\mathrm{Ku}^{\mathrm{P}}$ Himottu 'kalapüügikoht Lauga jõel', mis võib tuleneda kas üldsõnast himottu 'himustatud' (vrd Ku milla himotab 'ma himustan') või samatähenduslikust muistsest isikunimest *Himottu (ee Himmot Himotu; Stoebke 1964: 20-21).

Naaskem mereloomuskohtade nimede juurde. Mitu kalapüügikohta on nimetatud küla järgi: $\mathrm{Lu}^{\mathrm{A} 1} \mathrm{Lu}^{\mathrm{ES}}$ Jõgõperää apaja 'Jõgõperä meestele kuulunud kalapüügikoht Mari laiu lähedal'; $\mathrm{Lu}^{\mathrm{ES}} \mathrm{Lu}^{\mathrm{A} 1}$ Laukaasuu apaja 'kalapüügikoht Mari laiu lähedal'; $\mathrm{Lu}^{\mathrm{ES}} \mathrm{Lu}^{\mathrm{A} 1}$ Liivčülää zbornõii apaja 'kalapüügikoht Mari laiu lähedal' < vn сборный 'koond-'; Lu ${ }^{\mathrm{Al}}$ Rajoo apaja; $\mathrm{Lu}^{\mathrm{ES}}$ Viib'a a apaja 'kalapüügikoht Mari laiu lähedal', $\mathrm{Lu}^{\mathrm{A} 1}$ Viib'jee apaja.

Loomanimetusega seondub $\mathrm{Lu}^{\mathrm{ES}}$ Hömöläizii apaja 'kalapüügikoht Mari laiu lähedal', Lu ${ }^{\mathrm{A} 1}$ Hömöläisii apaja < hömöläin $\sim$ hämöläin : hömöläizii 'ämblik : ämblike'. Pole välistatud, et tegu on mõne küla või külaotsa rahva pilkenimega. Inimesega või inimkollektiivi nimetusega liituvad sekundaarsed $\mathrm{Lu}^{\mathrm{Al}} \mathrm{Lu}^{\mathrm{ES}}$ Kö̈̈häläizee apaja 'kalapüügikoht Mari laiu lähedal' < sm köyhäläinen 'vaene inimene'< kö̈̈hä 'vaene; vilets'; M ${ }^{\mathrm{A} 1}$ Savviõjaa apajad; Lu ${ }^{E S}$ Savõjaa artõli apaja 'kalapüügikoht Mari laiu lähedal' < artteli $\sim$ artelli $\sim$ artôlli 'siin: nooda- või paadimeeskond püügivahendi ühiseks kasutamiseks' ja $\mathrm{Lu}^{\mathrm{ES}}$ Vanaa arttõlii apaja 'kalapüügikoht Mari laiu lähedal'.

\subsection{Järvenimed}

Järvenimede liigisõnaks on Kattila murdes jarvi, mujal järvi. Loodusobjektiga seondub käesoleval sajandil talletatud kohanimi $\mathrm{Vp}^{\mathrm{B}}$ Ранта (Ranta) (= Мустоярве [Mustojärve]) 'mingi Luuditsa jõega 
seostuv järv', samuti ehk $\mathrm{Ku}^{\mathrm{P}}$ Haablaa järvi, vdj (= Saira, vt allpool) < Haapala (vn озеро Хабалово; 1676 Habala Jarfwi, OBG; 1704 Haballa Jarfwi, GCI). Loomariigi esindajate nimetusest on lähtunud $(\mathrm{Ku})^{\mathrm{P}}$ Karassijärvi, $\mathrm{Ku}^{\mathrm{E}}$ Karassi-järvi < karassi 'koger' < vn кapacb; $\mathrm{X}^{\mathrm{A} 2}$ Kukkora 'järv Mati lähistel' < kukkura 'udar' < 'kukkur'; Sudaga järvi 'Sudelje [?] järv' (= Palokkaa järvi, vt allpool) < sudakka: sudakaa sutakka : sutakaa 'sudak, koha' < vn cyдaк; $\mathrm{X}^{\mathrm{T}}$ Sudačjejärvi (vn озеро Cудачье). Taimenimetuse on pärinud (Ra) ${ }^{\mathrm{EK}}$ Vehkjärvi 'Võhkjärv Luuditsa lähedal', $\mathrm{Lu}^{\mathrm{EK}}$ Võhkajärvi, $\mathrm{JK}^{\mathrm{EK}}(\mathrm{Lu})^{\mathrm{EK}}$ Võhkõjärvi $\sim$ Võhkjärvi, $\mathrm{Lu}^{\mathrm{ES}}$ Võhkõojärvi 'järveke Luuditsa ja Rüsümäe vahel', Li ${ }^{\mathrm{A} 1}$ Võhkajärvi (vn озеро Леший) 'Lauga lahe ja Haapala järve vahel' < vehkaroho vehko $\sim$ võhka 'võhk'.

Järve ja selle vee omadusi kirjeldavad $\mathrm{Vp}^{\mathrm{B}}$ Мустоярве [Mustojärve, tegelikult pigem Mustajärvi] < musta 'must'; (Kõ) ${ }^{\mathrm{A} 1} \mathrm{M}^{\mathrm{A} 1}(\mathrm{M})^{\mathrm{EK}}$ Süvä jarvi, $\mathrm{M}^{\mathrm{EK}}$ Süväjarvi, $\mathrm{V}^{\mathrm{EK}}$ Süvä järvi (vn озеро Глубокое; 1704 Söfwa Jerfwi, GCI) < süvä 'süva, sügav'; Li ${ }^{E K}$ Valkaajärvi 'järv Hamala kandis' $<$ valkaa valkõa 'valge', Ku ${ }^{\mathrm{P}}$ Valkia järvi 'järv Pärspää neemel' (vn озеро Белое) < valkia 'valge'.

Usundiga seonduvad vadja- ja poolvenepärased Jarvikoisjärve nimevariandid $\mathrm{K}^{\mathrm{A} 1}$ Baabinskoi jarvi, Li ${ }^{\mathrm{A} 1}$ Babina järvi, $\mathrm{M}^{\mathrm{A} 1} \mathrm{M}^{\mathrm{A} 2}$ Jarvigoizjarvi, $\mathrm{M}^{\mathrm{EK}}$ Järvikoisjärvi (vn озеро Бабинское), samuti $K u^{P}$ Leeššoo järvi (= Talittu järvi, vn озеро Леший) < vn леший 'metshaldjas'. Esimesena nimetatud järve kutsutakse küla järgi ka $(\mathrm{M})^{\mathrm{A} 1}$ Savvokkala jarvi. Ebaselget päritolu talittu esineb teisteski kohanimedes (vt 2.1 ja 2.2). Jarvikoisjärvi on kandnud 1618.-1623. aasta kaardil ka nime Leuontieuo Osero (JI: 57) ja 1676 Muckowa Insiö (OBG); esimesel juhul on tegu isikunimega, viimane toponüüm kajastab külanime (vt Ernits 2020: Muuka).

Eriti vanad võivad olla suuremate järvede nimed, mis on ka enamasti läbipaistmatu etümoloogiaga: $(\mathrm{Lu})^{\mathrm{EK}}$ Koppõni järvi (= Peipijä järvi, vn озеро Копанское, külake Пейпия; 1676 Корропi Jarfwi, OBG; 1704 Kopponi Jerfwi, GCI; 1770 Озеро Копенское, KSP); M ${ }^{\mathrm{A} 1}$ Palokka jarvi (= Sudaga järvi, vn озеро Cудачье), $\mathrm{Ku}^{\mathrm{P}} \mathrm{Li}^{\mathrm{A} 1}$ Palokkaa järvi $<$ ? is palogaz 'paljude kaunadega (hernes)' või ? sm palokas 'põleng' (vrd is Palokkaaj järvi 'järv Soikkola lähistel'; mõlema lähtesõna õigsuse korral oleks järvenimi sekundaarne, vt ka Ernits 2020); $\mathrm{Lu}^{\mathrm{EK}} \mathrm{M}^{\mathrm{EK}}$ Peipijä järvi, $\mathrm{X}^{\mathrm{A} 2}$ Peipijää jarvi; $(\mathrm{K})^{\mathrm{EK}} \mathrm{Li}^{\mathrm{EK}} \mathrm{Lu}^{\mathrm{EK}} \mathrm{M}^{\mathrm{EK}}$ Peipiä, $\mathrm{Ku}^{\mathrm{P}}$ Peipiää järvi (= Koppõni järvi; etümoloogiliselt kõrvutatud Peipsi 
järve nimega, vt EKNR); $\mathrm{J}^{\mathrm{EK}} \mathrm{Ko}{ }^{\mathrm{EK}} \mathrm{Li}^{\mathrm{EK}} \mathrm{Lu}^{\mathrm{EK}} \mathrm{M}^{\mathrm{EK}}$ Saira, $(\mathrm{M})^{\mathrm{EK}}$ Sairavõ $\sim$ Sairõvõ, Li ${ }^{\mathrm{EK}}$ Saira järvi, $\mathrm{M}^{\mathrm{EK}}$ Sairajarvi $\sim$ Sairavõõ jarvi, $\mathrm{X}^{\mathrm{T}}$-Alava Haapalanjärvi $\sim$ Saivarojärvi (is Saira $\sim$ Sairaj [= Sairan] järvi, vn озеро Хаболово, vrd ee Saire 'endise küla nimi', vt EKNR; lähemalt Ernits 2020). ${ }^{16}$

Koppõni-nimetus (vrd ka isuri külanimi Koppani) on võetud ilmselt vene keelest, kuhu see võis olla laenatud omakorda mõnest läänemeresoome sõnast kujul *kapan, vrd ee Kapa oja 'jõgi Viljandimaal', Kapa järv 'Kavandi Suurjärve paralleelnimi Tartumaal', Kapa järv $\sim$ Kapa laht 'endine järv Läänemaal' (EJO: 114, EJN: 37, EKN). Seega sobiks lähtesõnaks vdj kappa 'kapp, kibu; mahumõõt' või is kappa 'mahumõõt; väike lohk maa sees; suur viljavihkude kuhi rehes' jt (vt EES: 129). Sel juhul esineb kohanimes genitiivitunnus $-n$, mis on vadja keeles pärastpoole kadunud, kuid isuri ja soome keeles säilinud. Järve nimi seondub tõenäoliselt selle pikerguse kujuga, mis on ühest otsast laienenud. Laenamisel võis $\operatorname{lms} a$ vene keeles $o$-ks muutuda, nt vad'd' $a$ 'vadja'> водb, vps lahti 'laht' > лохта, maksa 'maks (elundina)' > мокса (Myznikov 2004: 369). Lähtesõna *koppa: *kopan 'pika varrega nõu' on ehk vähem tõenäoline. Vene keeles on läänemeresoome kohanimi seostunud verbi коnать 'kaevama' tuletisega копань 'vee kogumiseks kaevatud süvend; madal kaev; kunstlik tiik; jõge järvega ühendav kraav; allikas; metsast puhastatud põld [puujuured on välja kaevatud]' (SNR XIV: 284). Teisalt pole võimatu, et järv on saanud venekeelse nime just viimati mainitud tähendusest.

Vanaaegsetel kaartidel on Sudaga Palokkaa järvi kandnud veel nimekujusid 1676 Polutzia Jarfwi (OBG), Polutsia Jerfwi (GCI) ja Чудское озеро (KSP). Kaks esimest nimevormi tulenevad venekeelsest külanimest, mis leidub juba 1500. aasta revisjonikirjas (vt Ernits 2020: Palokka). Viimane toponüüm on eriti huvitav, sest on täpselt samakujuline nagu Peipsi järvel, st Tšuudijärv ja võib etnonüümina osutada vadjalaste piiriasendile (vrd Ernits 2020: Tiutitsõ). Mõistatuseks jääb, kas just Чудское pole pärastpoole muutunud Судачье järveks või hoopis vastupidi või on kumbki nimi siiski ise päritolu.

16 Kukkuzi küla lähedal asuvat Lauga ja Mustjõe (vdj Joki, vn Чёрная) ühinemiskohta moodustunud veekogu nimetatakse vene keeles Куровицкое озеро 'Kukkuzi järv' (Talve 1981: 1.6). Vadjakeelne nimi võis olla *Järvi (vt 3.1). 
Järvenimede hulgas leidub mitu toponüümi, millel determinant puudub: Kukkora, Peipiä, Ranta ja Saira. Eelviimasel juhul võib olla liigisõna ärajätmine talletaja eksimus. Sekundaarselt on neeme- või külanimest tuletatud $\mathrm{Lu}^{\mathrm{EK}}$ Pärnispä̈̈ järvi (vn озеро Липовское <липа 'pärn') ja $\mathrm{M}^{\mathrm{EK}} \mathrm{M}^{\mathrm{Al}}$ Savvokkalaa jarvi (= Jarvikoisjärvi). Mererannanimest tuleneb vist liigisõnata järvenimi $\mathrm{Li}^{\mathrm{EK}} \mathrm{Lu}^{\mathrm{EK}}(\mathrm{Ra})^{\mathrm{EK}}$ Muussa $(\mathrm{vt}$ 2.1, 3.1, 4.4 ja 5.2).

\subsection{Jõenimed}

Jõenimede determinandiks on Vaipooles jõki ja Kukkuzis joki, mujal aga jõči 'jõgi'. Terminnimedena on talletatud Luuditsa külast läbi voolava Tõrvajõe nimi $(\mathrm{Lu})^{\mathrm{ES}}$ Jõki ja Kukkuzi küla juures voolava Tšornaja jõe (see pole Lu Mussajõki) nimi $\mathrm{Ku}^{\mathrm{E}}$ Joki. Rahvapärane jõgede nimetamine ei ühti alati ametlike nimedega, sest jõe kulgu ja lisajõgesid ei tuntud piisavalt.

Loodusliku objekti järgi saab liigitada $\mathrm{X}^{\mathrm{A} 2}$ Jugaa jõči, $\mathrm{K}^{\mathrm{EK}}$-Salminen $\mathrm{R}^{\mathrm{EK}}$-Europaeus Jugajõči 'Narva jõgi' < *juka 'juga, kosk', vrd (K R) Juka : Jugaa 'Joala [esialgu küla, hiljem mõis]', J Jugaa čerikko 'Narva-Joala kirik [= Narva Aleksandri Suurkirik Joaorus]'; $\mathrm{J}^{\mathrm{A} 1} \mathrm{Ku}^{\mathrm{P}}$ Laugaz, $\mathrm{M}^{\mathrm{EK}} \mathrm{M}^{\mathrm{A} 1}$ Laugazjõči, $\mathrm{X}^{\mathrm{A} 2}$ Laugazjõ či Laugazjõki (Vaipooles), $\mathrm{J}^{\mathrm{A} 1}$ Laukaa jõki, JEK-Mustonen Laukaajõtsi 'Lauga jõgi' (is Lauas Lauvaz : Laukkahan, vn Jyza) < *laugaz : *laukaa 'laugas', ent vrd ka langaz võrgurida; $\mathrm{Li}^{\mathrm{A} 1}$ Mettsäjõki 'Tõrvajõega ühinev jõgi Luuditsas' $<$ mettsä 'mets'; $\mathrm{M}^{\mathrm{EK}} \mathrm{M}^{\mathrm{A} 1}$ Narvaa jõči, $(\mathrm{Lu})^{\mathrm{A} 1}$ Narvaa jõki $<*$ narva 'künnis, kosk' (vt EKNR). J ${ }^{\mathrm{Ts}}$ Narov 'Narva jõgi' ja Ku $\mathrm{K}^{\mathrm{P}}$ Naroova on vadja keelde üle võetud vn Нарова vahendusel. Kahe suure jõe Lauga ja Narva nime päritolu seletamiseks on tehtud teisigi ettepanekuid.

$\mathrm{Ka}$ teiste suuremate jõgede nimed on vanad ja nende päritolu ena-

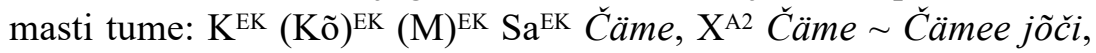

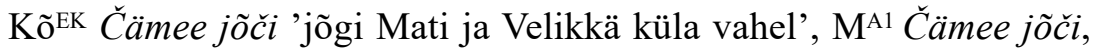
$\mathrm{Sa}^{\mathrm{A} 1} \mathrm{X}^{\mathrm{T}}$ Čämejõ či (vn Kямишu, vrd Kemi Soomes jpt, SPK); $\mathrm{J}^{\mathrm{Ts}}$ Roson, $\mathrm{J}^{\mathrm{EK}} \mathrm{Ku}^{\mathrm{P}} \mathrm{Lu}^{\mathrm{EK}}(\mathrm{Ra})^{\mathrm{A} 1}$ Rosona (vn Poccoнb); Ku${ }^{\mathrm{P}}$ Seestajoki, ${ }^{\mathrm{EK}}$ Siista Siistaa jõči 'Siista jõgi' (vn Cucma); I ${ }^{\mathrm{EK}} \mathrm{P}^{\mathrm{EK}}$ Suma, $\mathrm{P}^{\mathrm{EK}}$ Sumaa jõči (vn Сума; vrd SPK: Summa). Seesta puhul vrd sm Seestaanjoki $<$ seestyä siestää 'kirgastuda, selgida' (SPK: Seesta). Vähem tõenäoline on lähtuda nimekujust Siista, mispuhul võrdlusaineseks oleksid ee siista, sm siisti 'puhas' (VMS II: 409), Kod Siissametsä eenäm 'heinamaa' (EK) 
$<$ ?*Siista-. Igatahes on jõenimi laenatud, sest puhtvadja nime ootaks kujul *Siissa nagu Kodavere murrakuski.

Ilmselt veekogu asendist johtuvalt on nime saanud $\mathrm{Lu}^{\mathrm{EK}}$ Kalmo jõki 'jõeke Luuditsas' < kalmo 'kalm, haud'. Rajatise järgi on nimetatud $\mathrm{Li}^{\mathrm{EK}}$ Müllü jõki 'jõgi Luuditsas' < müllü 'veski'. Loomanimetusest, mis ilmselt kajastab jõe looklevat kulgu, on tekkinud toponüüm $\mathrm{Li}^{\mathrm{ES}}$ Matoojõ ki [õige on Matojõki] 'Valgovitsa poolt Kõhtsõ suunas voolav jõgi', Li ${ }^{\mathrm{A} 1}$ Matojõki < mato 'madu; uss'.

Pole selge, kas on tegu oja või jõekesega Jõgõperä küla vahel ja millise objekti nime saab pidada primaarseks determinandita toponüümi $\mathrm{J}^{\mathrm{EK}} \mathrm{Lu}^{\mathrm{EK}} \mathrm{Ra}^{\mathrm{EK}}$ Bräcägä puhul. Nimi tähistab ka porist soostunud nõgu. Rajo külast on see talletatud jõenimena: Ra ${ }^{\mathrm{Al}}$ Bräcägä 'jõgi Jõgõperäl'; $\mathrm{Ra}^{\mathrm{A} 1}$ Bräččägää jõki 'jõgi Jõgõperäl'. Jõe või oja nimi tuleneb üldsõnast bräčägä 'pori, muda'.

Jõevee või -ümbruse omadustega on seotud $\mathrm{ka} \mathrm{Lu}^{\mathrm{EK}}$ Mussajõki (vn Чёрная река) 'jõgi, mis läbib Jarvikois- ja Palokka järve' [Tegelikult ei läbi neid järvi, vaid on Aapala jõe lisajõgi] ${ }^{17} ; \mathrm{Lu}^{\mathrm{A} 1}$ Mätäjõ $k i$ 'oja Luuditsa lähedal; seal pestakse pesu' > mätä 'mäda, mädanenud'; Li ${ }^{\mathrm{EK}}$ Tõrvajõki Tõrva-jõki, $\mathrm{Li}^{\mathrm{A1}} \mathrm{Lu}^{\mathrm{Al}}$ Tõrvajõki, $\mathrm{Li}^{\mathrm{EK}} \mathrm{Lu}^{\mathrm{EK}}$ Tõrv-jõki 'Tõrvajõgi, läbib ka Jõgõperä [tegelikult ise ei läbi, vaid selle lisajõgi]', $\mathrm{Lu}^{\mathrm{EK}}$ Tõrvõjõki, Lu ${ }^{\mathrm{ES}}$ Tõrvajõki 'jõgi Liivčülä ja Rajo vahel [tõenäolisemalt Liivčülä ja Jõgõperä vahel]'< tõrva 'tõrv' (vn Смолка, ametlikult Lužitsa, vn Лужииа). Usundilise tagapõhjaga on $\mathrm{X}^{\mathrm{A} 2}$ Pühä jõ či 'jõgi Jarvigoiščülä lähedal', Ku ${ }^{\mathrm{P}}$ Pühäjoki 'Jarvikoisjärvest Haapala järve voolav jõgi' < pühä 'püha'. Selle jõe puhul on Kukkuzi vadjalased kasutanud ka venekeelset nime $\mathrm{Ku}^{\mathrm{P}}$ Svjatorečka $<$ vn святой 'püha' + речка 'jõeke' (ametlik nimi Святая).

Osa sekundaarsetest jõenimedest pärineb külanimest: $\mathrm{X}^{\mathrm{T}}$ Aapala jõči (= Kõhtsa jõki, vn Хабаловка, is ${ }^{\mathrm{T}}$ Koskisen jogi) ['jõgi, mis algab Haapala küla juurest Haapala järvest ja suubub Lauga lahte']; M ${ }^{\mathrm{A} 1}$ Kattiloizjõóci; Lu ${ }^{\mathrm{EK}}$ Kõhtsa jõki Kõhtsaa jõki; $\mathrm{Lu}^{\mathrm{ES}}$ Kõhtsõõ jõki (vn Косколовка = Белая) 'jõgi Kõhtsõ küla juures [Haapala jõe lisajõgi]' $\mathrm{Lu}^{\mathrm{A} 1} \mathrm{Lu}^{\mathrm{ES}}$ Luutsaa jõki 'jõgi, mis moodustub Tõrvajõe ja Rüsümäe jõe ühinemisel' [kaardi järgi algab Luuditsa jõgi Zavironski Mohhi soost]; $\mathrm{Lu}^{\mathrm{ES}}$ Rizümäee jõki 'Rüsümäe poolt voolav, moodustab Tõrvajõega

17 Ilmar Talve (1981: märkus 47) ühendab ebaõigesti jõenimed Mussajoci [!] ja Muussa, kohanimekartoteegi kaart aga jõenimed Mussajõki ja Kõhtsa jõki. 
Luuditsa jõe' [tegelikult vist Luuditsa lisajõgi]; $\mathrm{M}^{\mathrm{A} 1} \mathrm{M}^{\mathrm{EK}}$ Räättelöizjõči 'jõgi Mati ja Kattila vahel', Ku ${ }^{P}$ Räättälä joki 'Suma jõgi'; Lu ${ }^{\mathrm{EK}}$ Savija, $\mathrm{Lu}^{\mathrm{EK}} \mathrm{Ra}^{\mathrm{EK}}$ Savi õja, $\mathrm{Lu}^{\mathrm{EK}}$ Savi-õja Savi õja jõki (vt 4.5).

Teisesed on ka $\mathrm{Vp}^{\mathrm{B}}$ vn Караколка $\sim$ Краколка [Karakolka Krakolka] ['Luuditsa jõe lisajõgi']; Lu' ${ }^{\mathrm{EK}}$ Kolkaa pää jõki 'jõgi Luuditsas [ilmselt ebatäpsus, vt 3.2]', Lu ${ }^{\mathrm{A} 1}$ Kolkaapää jõki; $\mathrm{X}^{\mathrm{A} 2} \mathrm{X}^{\mathrm{T}}$ Muussa 'jõgi Vaipooles' (vt 2.1, 3.1, 4.3, 5.2); $\mathrm{Li}^{\mathrm{Al}}$ Palokka jõki. Mainitutest esimese jõe nimi ühendatakse sõnadega karu + kolkka 'nurk; kolgas kõrvaline koht', vrd sama jõe ääres asuva küla nime Jõgõperä < jõki : jõgõo 'jõgi : jõe' + perä 'pära, tagaosa'.

Liigisõnata jõenimed on Bräcägä, Čäme, Laugaz, Muussa, Narov, Narova, Rosona, Siista ja Suma. Toponüüm Savi õja jõki on tekkinud nõnda: primaarsest ojanimest on kõigepealt saanud külanimi ja sellest omakorda jõenimi.

\subsection{Ojanimed}

Vadjalastel on üsna palju ojade nimesid. Ojanimede liigisõnaks on $\tilde{o j a} \sim \mathrm{Ku}$ oja. Vadjalased nimetasid ojja'ks igasuguseid pesupesemise kohti, olgu see siis oja või tiik (VKS), nt $\mathrm{M}^{\mathrm{EM}}$ Uhtoma õja (VKSis üldnimena) < uhtoa 'kurikaga pesu pesta'. Eriline sõna on roostese veega oja jaoks, nimelt auččigõ 'maakeoja', mis on ühel juhul terminnimeks: $\mathrm{I}^{\mathrm{EK}}$ Auččigõ 'oja Ičäpäivä küla lähedal'.

Kõige sagedamini on oja saanud oma nime selle eriomaduse järgi: $\mathrm{M}^{\mathrm{EK}}$ Kaatsaa reisi 'kahe haruga oja Mati lähedal' (ka soo, vt 2.2); $\mathrm{Lu}^{\mathrm{ES}}$ Pičõja 'väike kuivav oja' < piččä 'pikk' (vrd E-Ing Pitkä oja 'heinamaa Väiküläs'); $\mathrm{Lu}^{\mathrm{ES}}$ Roosõ õja (talletatud ainult põllunimes, vt 5.1) < roosõ 'rooste'; (M) ${ }^{\mathrm{EK}}$ Savviõja 'oja Matist Velikkäle minnes' < savi savvi; $\mathrm{Ra}^{\mathrm{EK}}$ Süvä õja 'oja Rajo lähedal', ${ }^{\mathrm{ES}}$ Süväõa 'oja, mis ristub Jõgõperält Rajole viiva teega veidi maad enne küla', J ${ }^{\mathrm{A} 1}$ Süvä-õja 'oja Rajost Jõgõperä poole'; Ku ${ }^{\mathrm{P}}$ Vuhaoja 'suur kaevatud kanal' < vuhata

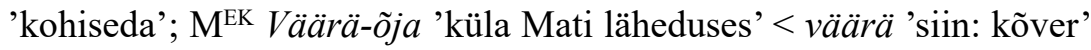
(vrd ka Väärnõjaa ranta, vt 3.1).

Looduskogumi järgi on nimetatud $\mathrm{Ra}^{\mathrm{EK}}$ Čivikkoõja 'oja Jõgõperä lähedal surnuaia juures', J ${ }^{\mathrm{EK}} \mathrm{Ra}^{\mathrm{EK}}$ Čivikkõja; J ${ }^{\mathrm{ES}}$ Čivikõja 'väike oja, mis voolab Jõgõperä kalmistu poolt vainule', J' ${ }^{\mathrm{A} 1}$ Čivikõja 'oja Jõgõperäl' < čivikko 'kivine; kivik, kivine koht'; $\mathrm{Ku}^{\mathrm{E}}$ Liivakko 'oja' < liivakko 'liivak, liivamaa'; Lu ${ }^{\mathrm{ES}}$ Mettsääõja [õigem oleks Mettsäõja 
või Metsäõja] 'oja Luuditsast lõuna pool metsas' (oja võiks liigitada ka asendist lähtuvalt). $\mathrm{Ku}^{\mathrm{P}}$ Palanikoo oja $<$ *palanikko 'põlenud koht' < palaa 'põleda' (vrd Kod Põleniku eenäm [= heinamaa] < põlenik 'põletik; põlenud koht metsas', EDW: 862, VMS II: 274; vt ka 5.2); $\mathrm{K}^{\mathrm{EK}}$ Võhmaz < *võhmaz 'soosaar', vrd ee võhmas (vt Päll 2020: 298).

Flooranimetustega on ühenduses Kõ ${ }^{\mathrm{EK}}$ Kapussõja 'oja ja heinamaa' < kapussa 'kapsas' < vn кanycma; Lu ${ }^{\mathrm{EK}}$ Leppoja $\sim$ Leppäoja < leppä 'lepp'; Lu ${ }^{\mathrm{A1}}$ Sõssõrõja, Vp ${ }^{\mathrm{B}}$ Cысырырыйя [Sõsõrõja] (Sosoroja) < sõssar sõssõr 'sõstar'. Viimase kohanime puhul jutustatakse Vadjamaal muistendit, mille kohaselt kuus oja-venda suubub Tõrvajõkke ühelt poolt ja vaid üks oja-õde teiselt poolt (Demina 2009: 42). Ühelt poolt võib siin tegu olla rahvaetümoloogiaga, millel pole keelelist alust (vrd sõsar $\sim$ sõsara $\sim$ sõzar 'õde, sõsar'), teisalt on mõeldav, et Sõssõrõja üleskirjutuses avaldub vene keele häälduse mõju, mistõttu täpsem kuju oleks sõsar 'õde'. Nõnda haakuks lugu ka keeleliselt.

Teiste täiendosadega on registreeritud vaid üksikuid ojanimesid. Loomanimetusest pärineb vaid $\mathrm{Lu}^{\mathrm{EK}}$ Matoõja $\sim$ Mato-õja 'oja Räätäli ja Kattila vahel; oja Korovaisi ja Kattila vahel' < mato 'madu; uss'. ${ }^{18}$ Inimese nimega seondub $\mathrm{Ku}^{\mathrm{P}}$ Kiriloja (heinamaa, vt 5.2) $<$ mehenimi Kirila < vn Кирилл; Lu ${ }^{\mathrm{ES}}$ Semenaаõja 'oja Rüsümäe juures' < mehenimi Semena < vn Семён; alemaa või karjaaiaga Kõ ${ }^{\mathrm{EK}}$ Roočita 'heinamaa ja oja [?]'. Usundiga võivad olla ühenduses $\mathrm{X}^{\mathrm{A} 2}$ Iiliä-õja 'oja Kõrvõttula lähedal' < Iiliä '(püha) Elias' ja L ${ }^{\mathrm{EK}}$ Iisi 'mingi oja', $\mathrm{X}^{\mathrm{A} 2}$ Iisi Iisi-õja 'oja Lempola lähistel' < *iisi 'hiis'. Piirimõistet väljendab Lu$\mathrm{Li}^{\mathrm{ES}}$ Rajaakanava 'Tõrvajõkke suubuv kraav Luuditsa ja Liivčülä vahel' < raja 'piir' + kanava 'kraav'. Is kannaava tähenduseks ongi toodud 'kaevatud kraav, sageli piirikraav'.

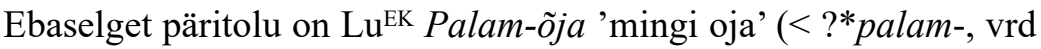
Palamuse < *palamus 'põlendik, alemaa', EKNR; seega oleks tegu sekundaarse nimega); $\mathrm{Ku}^{\mathrm{P}}$ Raizikoo oja (vt 5.2); $\mathrm{M}^{\mathrm{Al}}$ Tuhaa kanava $<$ ? is tuhka : tuhan 'tuhk : tuha', vrd vdj tuhka : tuhgaa (kohanimes avaldub ehk vadja keele isuri- või soomepärasus); $\mathrm{Vp}^{\mathrm{B}}$ Выпnала [Võpala] 'laste supluskoht Luuditsas'.

18 Luuditsa keelejuht Miko Pimenov jutustas: Siäll on õja. Kutsutaa Mato-õja. Jutõllaa, što kukali mato meni, sikäli tuli õja 'Seal on oja. Kutsutakse Maduoja. Räägitakse, et kustkaudu madu läks, sinna tuli oja' (VE III 142). 
Sekundaarset algupära on ojanimed $\mathrm{Ra}^{\mathrm{EK}}$ Halikaa oja 'Rajo küla läbiv oja, mis suubub Lauga jõkke' (vt 2.3); $\mathrm{Ku}^{\mathrm{P}}$ Siltuitto < silta 'sild' + uitto 'madal vesine koht'; $\mathrm{Li}^{\mathrm{A} 1}$ Greivi 'merre suubuv oja'. Mõned ojanimed on liigisõnata, nagu Greivi (mitme maismaaobjekti nimes), Iisi, Kaatsaa reisi (ka soonimi), Roočita (ka heinamaa), Siltuitto ja Võhmaz.

\subsection{Allikanimed}

Allikanimede liigisõnaks on lähe 'läte, allikas', vaid ühel juhul on allikas saanud tuntuks Kõ ${ }^{\mathrm{A} 2}$ Kupol'oo kaivo (< kupol'o 'jaanipäev' + kaivo 'kaev') nime all, sest talle olid rakked ümber ehitatud.

Enamik nimelisi allikaid on usundilise tagapõhjaga. Vaimulikuga (või haldjaga?) või pühakunimega on seotud $\mathrm{J}^{\mathrm{A} 1}$ Papii lähe 'allikas Jõgõperäl' < pappi 'preester, papp; haldjas' (vrd kaivoz on kaivuo pappi 'kaevus on kaevuhaldjas'); JEK Sergelähe 'Sergei allikas Jõgõperä küla lähedal', ${ }^{\mathrm{A} 1} \mathrm{Ra}^{\mathrm{A} 1} \mathrm{Ra}^{\mathrm{ES}}$ Sergei lähe (= Limonadka) < mehenimi Serge $<$ Sergei (vn Cepzeŭ, vrd ka se Serge; Saar 2016: 173). ${ }^{19}$ Viimati mainitud allika juures olevat seisnud tulp Sergei Imetegija ikooniga, allikavett kasutatud silmahaiguste raviks. Rajo keelejuht Oudekki Figurova väitis, et nimi olevat pandud hoopis läheduses elanud tõrvakeetja Sergei järgi. Venekeelne paralleelnimi $\mathrm{Vp}^{\mathrm{B}}$ Лимонадка [= Limonadka], mida kasutavad ka vadjalased ( $\mathrm{Lu}^{\mathrm{EM}}$ Limonatti-mäči), pärineb Teise maailmasõja eelsest perioodist, mil lättest võeti vett limonaadi valmistamiseks, kuid sõda takistas joogi tööstusliku tootmise algust (Demina 2009: 43). Maagilise raviga seondub ilmselt ka L ${ }^{\mathrm{A} 2}$ Silmä-lähe < silmä 'silm'. Usundilise sisuga on veel eespool nimetatud $\mathrm{Kõ}^{\mathrm{A} 1} \mathrm{Kõ}^{\mathrm{A} 2}$ Kupol'oo lähe 'allikas Kõrvõttulas mäerinnaku all' < kupol'o 'jaanipäev' (vrd vn праздник Ивана Купальь 'Ristija Johannese püha'. ${ }^{20}$

19 Jõgõperä keelejuht Mari Petrova jutustas: Ku silmii vaivattii, pühittii silmii. I se rätte jätettii Sergei lähteesee. Siäll õli pikkarain obraz. Siäll ôli mikälee sammaz. I sampaaz ôli obraz. Siäll õli Sergei čudotvorets 'Kui silmad olid haiged, pühiti [rätikuga] silmi. Ja see rätik jäeti Sergei lättesse. Seal oli väike ikoon. Seal oli mingi post. Seal oli Sergei Imetegija [ikoon]' (VE XIV: 126; Ariste 1977: 39).

$20 \quad$ Ilmar Talve (1981: 1.2.1) nimetas Kattila külaga seoses Iiliä allikat, kuid vadjakeelset nime ei esitanud, küll aga toonud samale toponüümile toetuva heinamaanime (vt 5.2). Asjaomase objekti nimi võiks olla (K)T *Iiliää lähe (pühaku nime kohta vt ka 2.1, 2.6, 4.5). 
Ülejäänud allikanimed on mitmesugust algupära. Puuliigi järgi on nimetatud $\mathrm{Ra}^{\mathrm{ES}}$ Aaplähe 'allikas Jõgõperäl', $\mathrm{Ra}^{\mathrm{Al}}$ Aaplähe 'ohvriallikas Jõgõperä Kunigvallas' < aapa 'haab'; vee külmuse alusel $\mathrm{V}^{\mathrm{A} 2}$ Čülmä lähe < cü̈lmä 'külm', rajatise järgi $\mathrm{M}^{\mathrm{A} 1}$ Rässedolähe < rässädo räässäto 'taimelava' < vn рассадник. Asendi põhjal eristub $\mathrm{M}^{\mathrm{A} 1}$ Č̈̈lää lähe < čülä 'küla' ja $\mathrm{M}^{\mathrm{A} 1}$ Üli jõgõo lähe 'ohvriallikas Mati lähistel'. Viimane toponüüm on nagu eespool käsitletud põllu- ja heinamaanimed Ülijoeepellod, Ülisillaapellod moodustatud eessõna ja ainsuse omastavas avalduva nimisõna abil (vrd ka Ülisillalla).

\subsection{Tiiginimed}

Säilinud on vaid kaks loodusliku tiigi nime, neist determinandita $\mathrm{M}^{\mathrm{A1}}$ Opõzii joottamin 'tiik Kattila ja Mati vahel' on olnud hobuste jootmise koht, vrd opõn : opõzii 'hobune : hobuste' + joottamin 'jootmine' ning sekundaarne $\mathrm{Lu}^{\mathrm{ES}}$ Sõssarõja 'tiik Luuditsa-Rüsümäe tee ääres', mis seondub ehk samanimelise oja nimega (vt 4.5). Kaevatud tiiki nimetati liko (vrd ee linaligu, is ligo), mida kasutati linaleotuseks ja pesupesemiseks.

\section{Viljelusnimed}

Kultuurmaastiku viljelusnimede hulka kuuluvad põldude ning heinaja karjamaade nimed.

\subsection{Põllunimed}

Juba Ilmar Talve märkis, et Vaipooles kasutatakse põllunimede liigisõnana põlto nagu isurid omakeelset pelto, mujal on tavalisem nurmi (Talvi 1981: 1.7). Apellatiiv sarka : sargaa (vrd is sarga : saran) tähendab ühele perele kuuluvat põlluriba kogukonna maast. Põllutükkide nimede Kõ ${ }^{\mathrm{EK}}$ Esimein $\log a$ ja Tõin $\log a$ determinant pärineb vene keelest, vrd лог 'pikk jäärak, uhteorg', mis on laenatud loga kujul ka isuri keelde (IMS). Otsustades sugulaskeelte sõna tähenduste järgi näib, et põllu- ja heinamaanimes kasutatav laita tähendab peale muu ka maatükki või maariba (vt ESS). ${ }^{21}$

21 VKS annab tähenduseks üksnes 'laid, veesõiduki küljelaud'. 
Põllunimede täiendosa võib tuleneda mõnest loodusliku objekti nimest, nagu $\mathrm{M}^{\mathrm{A} 2}$ Čivirõukko-nurmi < čivirõukko 'kivikangur, kivihunnik'; Kü Kivikoo pellod < kivikko 'kivistik' (vrd is Kivikkosarad, IMS: sarga); $\mathrm{Lu}^{\mathrm{ES}}$ Mättelikoo sargad 'põllumaa mere ääres Liivčülä all' < mättälikko 'mätlik; mätastik' (vrd E-Ing Mättälikku 'heinamaa Väiküläs'); I ${ }^{\mathrm{EK}}$ Nõmmiznurmi 'mingi põld', I ${ }^{\mathrm{A} 2}$ Nõmmiz-nurmi < *nõmmin 'nõmmene, nõmme-'; Lu ${ }^{\mathrm{ES}}$ Saaripõlto 'põllumaa Tõrvajõe ääres', $\mathrm{Lu}^{\mathrm{EM}}$ Saar-nurmi < saari 'saar'. Põldude nimetamist mõne looma või puuga seonduvalt esineb harva: ${ }^{\mathrm{A} 2} \mathrm{I}^{\mathrm{EK}}$ Aapa-nurmi < aapa 'haab'; Ra ${ }^{\mathrm{A} 1}$ Koerpõlto 'põld Jõgõperä küla taga', $\mathrm{J}^{\mathrm{A} 1}$ Koirapõlto $\sim$ Koirpõlto, hiljem vn Собачье поле < koira 'koer'; Lu ${ }^{\mathrm{EK}}$ Kotkaa pezäd 'põld Rüsümäe lähedal' < sm kotka 'kotkas (vrd vdj kotko : kodgoo, is kokkoi)' + pesä 'pesa'; $\mathrm{Ku}^{\mathrm{P}}$ Raizikko 'kord põld, kord heinamaa'< * raizikko 'rägastik', vrd Viljandimaa räisik 'rägastik'; deskriptiivse sõna puhul on vaheldus $a \sim \ddot{a}$ täiesti võimalik, nt ee raisk $\sim$ räisk 'raibe; praht' (VMS II: 305, 357 ; vt ka 5.2). ${ }^{22}$

Rohkem on põlde nimetatud asukoha järgi: $\mathrm{Lu}^{\mathrm{ES}}$ Kalmojõõ nurmi 'põllumaa Luuditsas kalmistu kõrval', $\mathrm{Lu}^{\mathrm{EM}}$ Kalmo-nurmi; $\mathrm{Li}^{\mathrm{ES}} \mathrm{Kuru}$ põllod 'põllumaa Tõrvajõe ääres', $\mathrm{Li}^{\mathrm{EK}}$ Kuru sargõd $<$ *kuru 'kuru, kõrvaline paik'; Ra ${ }^{\mathrm{A} 1}$ Mäe päälüz 'põld Jõgõperäl' < mäči : mäee 'mägi' + päälüz päällüz 'pealne'; Ra ${ }^{\mathrm{A} 1}$ Ojjaperä 'põld Jõgõperäl' < õja 'oja' + perä 'siin: pära, tagaosa'; $\mathrm{M}^{\mathrm{A} 2}$ Rajanurmi; $\mathrm{Ku}^{\mathrm{P}}$ Rajapellod 'põllud Kukkuzi ja Kotko piiril' < raja 'piir'; Lu ${ }^{\mathrm{ES}}$ Rantapõllod 'Luuditsa mereäärsed põllud' < ranta 'rand'; Ku Ülijoeepellod < üli 'üle, teiselpool' + joki 'jõgi' (vrd is Ülijoempeldo Soikkola poolsaarel, IMS: peldo); $\mathrm{Li}^{\mathrm{ES}}$ Ülisillaapõllod 'põllumaa Tõrvajõe Jõgõperä-poolsel kaldal'; Li ${ }^{\mathrm{EK}}$ Ülisillalla 'põld Liivčüläs', Li ${ }^{\mathrm{A} 1}$ Üli sillalla 'mingi põld' < üli 'üle' + silta 'siin: sild'.

Inimese ees- või hüüdnimi avaldub toponüümides $\mathrm{Li}^{\mathrm{A} 1} \mathrm{Li}^{\mathrm{ES}}$ Elotilkaamaa 'põllumaa, eestlase järgi, kes laulnud ikka: „Elu tilk-tilktilk!"“; Ku ${ }^{\mathrm{P}}$ Jefimpelto (nimekartoteegis põllunimena pole) < mehenimi Jefim < vn Equм; $(\mathrm{Ku})^{\mathrm{T}}$ Jessinpelto (talletatud ainult soo ja heinamaa nimes, vt 2.2 ja 5.2) $<$ ?mehenimi *Jessi $<$ Jefim (tõenäoliselt nii nagu

Sama vaheldust võib oletada ehk ka jõe nimest tuletatud soome linnanime Raisio (1292 Resum, 1302 in Reisum; SPK) puhul, sest toonane kirjapanek võiks kajastada nii $e$-d kui ka $\ddot{a}$-d. Ehk kuuluvad siia rühma ka is Razi (mets) ja Razikka (mets, rand) ning viimasest tuletatud sekundaarnimed. 
viimasest on tekkinud Karjalast talletatud Jeska $\sim$ Jes 'ko; vt SSN: 348; vrd ka Еся < Евсевий või Евстафий; vt ka 2.2 ja 5.2); Lu ${ }^{\mathrm{ES}} V a n^{\prime} a a$ laita 'põllumaa Lauga idakaldal' < mehenimi Van'a $<$ vn Ваня $<$ Иван. Ametinimetust märgib $\mathrm{K}^{\mathrm{A} 2}$ Papii nurmi.

Huvi pakuvad põllunimed $\mathrm{Li}^{\mathrm{Al}} \mathrm{Lad}^{\prime} \mathrm{d}^{\prime}$ a pers 'põld [ja heinamaa]' $<$ lad'd'a 'lai' + perz perze 'tagumik' (kas inimese hüüdnimi või põllu kuju kirjeldav sõna); Lu ${ }^{\mathrm{ES}}$ Papičennää sargad 'põllumaa Liivčülä all mere ääres' < pappi 'papp, preester; haldjas' + čenčä : čennää 'king'.

Põldude nimetamisel on teisi täiendosatüüpe kasutatud väga harva. Omadust kajastavad vaid $\mathrm{Ku}^{\mathrm{P}}$ Suuri väljä, $\mathrm{Ku}^{\mathrm{T}}$ Suurväljä (heinamaa, vt 5.2) < suuri 'suur' + väljä 'väli, põld' ja $\mathrm{J}^{\mathrm{A} 2}$ Vana põlto, $\mathrm{M}^{\mathrm{EK}}$ Vana põlto 'põld Mati külas' < vana. Seosele külaga osutab (Kõ) ${ }^{\mathrm{EK}}$ Korvaizpõlto 'põld Korovaisi lähedal' ( $<\mathrm{sm}$ Korovaisi). Sisuliselt arusaamatuks jääb $\mathrm{Ku}^{\mathrm{P}}$ Kaivatavvaa pellod $<$ ? kaivattava $\sim$ kaivõttava 'kaevatav' (vt ka 2.1).

Põllunimedes Kotkaa pezäd, Lad'd'a pers, Mäe päälüz, Ojaperä ja Raizikko determinant puudub. Toponüüm Kalmojõõ nurmi täiendosa on mitmuses genitiivis. Ainult kahes põllunime atribuudis esineb eessõna üli 'üle': Ülijoeepellod, Ülisillaapellod ja liigisõnata põllu- ja heinamaanimi alalütlevas käändes Ülisillalla.

Rohkesti leidub sekundaarseid põllunimesid. Nad seonduvad looduslike objektidega (heinamaa, oja, soo jt), nagu $\mathrm{Lu}^{\mathrm{ES}}$ Čirppusoo sargad 'põllumaa metsas Liivčülä ja Jõgõperä vahel' (soonimena pole registreeritud; vt 2.2); $\mathrm{Ku}^{\mathrm{P}}$ Hijjezmaa nurkka 'mingi põld' < *hijjene < *hiisi 'hiis', vrd Ku${ }^{\mathrm{P}}$ Hijjee nukka 'neem Lauga jõe ja Kukkuzi järvest algava lisajõe vahel'; Lu ${ }^{\mathrm{ES}}$ Kazikooniitüü põllod 'põllumaa Luuditsast ida poole' (vt 5.2); Ra ${ }^{\mathrm{Al}}$ Lehtoniittü 'põld Jõgõperäl' < lehto 'siin: lehtmets' (heinamaanimena pole talletatud; vt 5.2); $\mathrm{Lu}^{\mathrm{EK}}$ Leppoja $\sim$ Leppäoja 'põld Luuditsa lähedal' (vt ka 2.1 ja 4.5), Lu ${ }^{\mathrm{EM}}$ Leppõja-nurmi, Lu ${ }^{\mathrm{ES}}$ Leppõjaa põllod 'kraavidega eraldatud põllulapid metsas Luuditsast ida poole' (võivad olla nimetatud ka Luuditsa idapoolse otsa, st Leppäõja ottsa nime järgi; ojanimest pole andmeid; vt 4.5); $\mathrm{Lu}^{\mathrm{ES}}$ Polmasoo(n) aluzõd sargad 'põllumaa Liivčüläst Jõgõperä poole' (vt 2.2); Lu ${ }^{\mathrm{ES}}$ Roosõõ õjaa põllod 'põllumaa Liivčüläst lääne pool Tõrvajõe ääres' (ojanimena kartoteegis puudub; vt 4.5) < roosõ 'rooste'; $\mathrm{Lu}^{\mathrm{ES}}$ Sarainiitüü sargad 'põllumaa mere ääres' (vt 5.2); $\mathrm{Ku}^{\mathrm{P}}$ Siltuitoo pellod (vt 4.5); $K u^{P}$ Suteselää pellod (mäeseljaku nimena pole kartoteegis; vt ka 2.1 ja 2.3). 
Asendist lähtuvad $\mathrm{Lu}^{\mathrm{ES}}$ Ivanpoolõ(n)allaa sargad 'põllumaa mere ääres Liivčüläst lääne poole' < mehenimi Ivan (< vn Иван) + pooli 'pool, kant' + alla 'all' (vt 5.2); Li ${ }^{\mathrm{A1}}$ Jõgõranta 'põld', Li ${ }^{\mathrm{ES}}$ Jõkõrantaa põllod (õigem oleks Jõgõõrannaa) 'põllumaa Tõrvajõe ääres' < jõki 'jõgi' + ranta 'rand, kallas; äär' (vt 3.1); Ku ${ }^{\mathrm{P}}$ Kalmmetsää pellod 'põllud sõjakalmude lähedal' < kalmo 'kalm' + mettsä 'mets' (ka metsanimes, vt 2.1); $\mathrm{Ra}^{\mathrm{Al}}$ Sõtikalmod (= Rootsii kalmod) Sõtikalmopõllod 'põllud Jõgõperä mäe all' < sõta : sõti 'sõda : sõdade' + kalmod 'kalmud; kalmistu'.23

Kukkuzi külaosade nimega seostuvad $\mathrm{Ku}^{\mathrm{P}}$ Alapaa pellod (vt 2.2) ja $\mathrm{Ku}^{\mathrm{P}}$ Dubrovaa nurmi. Sekundaarsed on ka põllunimed $\mathrm{Ra}^{\mathrm{A} 1}$ Taloniittü (ka heinamaa, vt 5.1) 'põld Jõgõperäl'; J ${ }^{\mathrm{A} 1}$ Taloniitüü mettsä $<$ talo 'talu; maja' + niittü 'niit, heinamaa' (kohanimekartoteegis ainult põllunimena; vt ka 5.2); $\mathrm{Ra}^{\mathrm{A} 1}$ Upamaa põllod' Jõgõperä põld, kus varasemalt kasvatatud uba'. Heinamaa nimetamine põlluks ja metsaks viitab nende varasemale kasutusalale.

\subsection{Heinamaanimed}

Heinamaanimede determinandiks on niittü 'heinamaa, niit, aas'. Vadjalastelt on teada suhteliselt palju heinamaanimesid. Koguja A. Lõhmus on kirja pannud ühe kohanime kujul $\mathrm{Lu}^{\mathrm{ES}}$ Saarniitüü sikku 'heinamaa Luuditsa ja Liivtšülä piiril'. See näikse viitavat tuletisele *niittüzikko 'mitmeosaline heinamaa?' (ainult tugevastmelisele sõnatüvele liituva kollektiivsufiksi -zikko kohta vt Ariste 1948: 127). Kirjapanijal on olnud mujalgi ebatäpsusi astmevahelduse kindlakstegemisel, nt Mettsää- õige Mettsä- või Metsää asemel.

Heinamaad on sagedamini saanud nime mõne loodusliku objekti järgi. Taimsete kogumite järgi on nimetatud $\mathrm{Ku}^{\mathrm{P}} \mathrm{Ku}^{\mathrm{T}}$ Koivikko $<$ is, sm koivikko 'kaasik'; J ${ }^{\mathrm{ES}}$ Lehtoo niittü 'endine heinamaa Jõgõperä koolimaja lähedal ristteelt Laugale mineva tee ääres; nime talletamise ajal kalatiikide all', J ${ }^{\mathrm{A} 1}$ Lehtniittü 'Jõgõperä Halikka otsa heinamaa', J ${ }^{\mathrm{A} 1}$ Lehto-niittü, $\mathrm{Ra}^{\mathrm{A} 1}$ Lehtoniittü < lehto 'leht; lehtmets'; $\mathrm{Ku}^{\mathrm{E}} \mathrm{Ku}^{\mathrm{T}}$ Lepikko

23 VKS annab üldsõnale Ra sõtikalmod tähenduseks 'sõjaaegsed kalmud'. Tegu on siiski Jõgõperä kohanimega, mis seostub muistendiga Rootsi-aegsetest kalmedest. Keelejuhi Oudekki Figurova teatel asunud seal kunagi kiviristid (VE XIII: 96, VE XVI: 99). 
< lepikko 'lepik'; Ku' Rookozikko Rookuzikko, Lu ${ }^{\mathrm{ES}}$ Rookozikoo niittü 'heinamaa Liivčülä all mere ääres' < rookozikko rookuzikko 'roostik'.

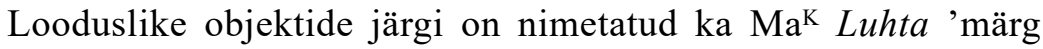
heinamaa Mahu lähedal' < luhta 'tarn; luht'; $\mathrm{Ku}^{\mathrm{E}} \mathrm{Ku}^{\mathrm{P}} \mathrm{Ku}^{\mathrm{T}}$ Palannikko $<$ *palanikko 'põlenud koht' < palaa 'põleda'; $\mathrm{Ku}^{\mathrm{T}}$ Raisikko, $\mathrm{Ku}^{\mathrm{P}}$ Raizikko 'kord põld, kord heinamaa' (vt 5.1); Lu ${ }^{\mathrm{EK}}$ Saarniittü 'heinamaa Luuditsa lähedal Koskolovo poole', $\mathrm{Lu}^{\mathrm{ES}}$ Saarniittü 'heinamaa mere ääres Luuditsa küla all' < saari 'saar'; J ${ }^{\mathrm{EK}} V_{a i n}$ 'o 'mingi heinamaa', J $\mathrm{J}^{\mathrm{A} 1}$ Vain'oniittü, Kõ ${ }^{\mathrm{EK}}$ Van'oniittü 'Jõgõperä Herrvalla heinamaa' < vain'o vainio 'vain, aas'. Pinnavormist lähtuvad Kõ ${ }^{\mathrm{E}} \mathrm{Ko}{ }^{\mathrm{EK}}$ Alakko 'mingi heinamaa' < alakko 'nõgu'; $\mathrm{Lu}^{\mathrm{EK}}$ Leesiniittü Leeziiniittü 'heinamaa Koskolovo suunas'< leesi 'leetseljak'.

Heinamaanimedes kajastuvad loomariigi esindajad: $\mathrm{Ja}^{\mathrm{A} 2}$ Čärppäzee niittü, $\mathrm{M}^{\mathrm{EK}}$ Čärppäzee niittü 'heinamaa Mati? küla lähedal' < adjektiivne *čärppän čärppäne : čärppäzee 'kärbi-; nirgi-'< čärppä 'kärp; nirk'; Ja ${ }^{\mathrm{E}}$ Kurč < kurči 'kurg'; K ${ }^{\mathrm{T}}$ Kurppa $<$ kurppa 'metskurvits', ka Hiiumaa kurp : kurba 'kurvits' (EDW: 343, 417), Jõh Kurba (talu; EK).

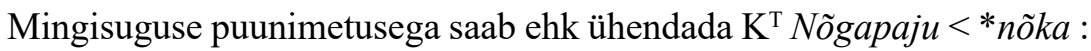
nõgaa '?' + paju 'paju; painardipuu', vrd vdj nõkata 'noogutada' ning ee nõga 'nõgu' ja nõgama 'nõtkuma' (VMS II: 112). Puunimetusega võib seostuda ka $\mathrm{M}^{\mathrm{EK}}$ Jallain 'mingi heinamaa', $\mathrm{X}^{\mathrm{A} 2}$ Jallain niittü $<*$ jalain 'jalakas', vrd jalaja $\sim$ jalakka $\sim$ jalanõ 'jalakas'.

Mõned heinamaad on nimetatud nende asukoha järgi veekogude suhtes: Kõ $\tilde{\mathrm{E}}^{\mathrm{E}}$ Ile-oja [Ülee-õja] < üli 'üle, teisel pool' + õja 'oja'; Kõ ${ }^{\mathrm{EK}}$ Jarviniittü, Kõ ${ }^{E}$ Jarviniittu [jarviniittü] < jarvi 'järv'; K ${ }^{\mathrm{T}}$ Ojavaije $<$ oja + *vaije 'vahe', vrd kreevini waijel 'vahel'; Li ${ }^{\mathrm{EK}}$ Rantaniittü 'heinamaa Liivčülä lähistel', $\mathrm{Lu}^{\mathrm{ES}}$ Rantaniittü 'heinamaa mererannas Luuditsa all' < ranta 'rand, kallas; äär, serv' (vrd is Randaniittü, E-Ing Rantniittü 'heinamaa Kullakülas'); $\mathrm{Li}^{\mathrm{A2}}$ Ülisillalla $<\ddot{u ̈ l i}$ 'üle, teisel pool' + silta : sillalla 'sild : sillal'.

Osa heinamaanimesid väljendab asendit külast kuskil kaugemal nurgas või kõrvalises paigas: $\mathrm{Ku}^{\mathrm{T}}$ Alapan niittü, $\mathrm{K} \tilde{\mathrm{E}}^{\mathrm{E}}$ Alapp $\sim$ Alappo 'heinamaa' (vt 2.2); Kolkkaniittü 'heinamaa Luuditsas' < kolkka 'nurk'; $\mathrm{Li}^{\mathrm{ES}}$ Kuruniittü 'heinamaa Tõrvajõe Jõgõperä-poolsel kaldal', $\mathrm{J}^{\mathrm{A} 1} \mathrm{Li}^{\mathrm{EK}}$ Kuru niittü 'Jõgõperä Herrvalla heinamaa', $\mathrm{Li}^{\mathrm{A} 1}$ Kuruu niittü $<$ kuru 'kuru, kõrvaline paik'. Selgesti väljendab heinamaa asukohta ilmselt hiline toponüüm $\mathrm{J}^{\mathrm{A} 1}$ Takadaatsoo niittü < taka 'taga' + daača : daačoo 'suvila : suvilaid'< vn. 
Omadust väljendavad järgmised heinamaanimed: Kõ ${ }^{\mathrm{E}}$ Emo-niitturooje [Emo-niittü-rooja] 'mingi heinamaa' < emo 'siin: suur' < emo 'ema; emake' + niittü + rooja 'pori' (vrd teisene Emoväl'l'ä); $\mathrm{Lu}^{\mathrm{EK}}$ Lakkia 'mingi heinamaa' < lakkia lakõa 'tasane; lage, paljas'; Ra ${ }^{\mathrm{EM}}$ Piččä-niittü < piččä 'pikk'; $\mathrm{Ku}^{\mathrm{E}} \mathrm{Ra}^{\mathrm{E}}$ Pitki-niittü < is pitki 'pikk'; $\mathrm{M}^{\mathrm{EK}}$ Roojôlla 'Mati küla alune heinamaa', $\mathrm{M}^{\mathrm{A} 1}$ Roojõlla 'heinamaa Mati ja Velikka vahel'< rooja : roojölla 'pori : poril'; Lu' ${ }^{\mathrm{ES}}$ Suurniittü (= Saraiiniittü) 'heinamaa Luuditsa ja Kõhtsõ piiril', J ${ }^{\mathrm{A} 1}$ Suurniittü, $\mathrm{Ra}^{\mathrm{A} 1}$ Suurniittü 'Jõgõperä Halikka otsa heinamaa', J' ${ }^{\mathrm{A} 1}$ Suur niittü < suuri 'suur' (vrd E-Ing Suurniittü 'heinamaa Kullakülas').

Inimesenimest või ametist tulenevad $\mathrm{Ra}^{\mathrm{E}}$ Borisuhha $<$ eesnimi Boris (vn Борис) + vn halvustav sufiks -uhha (-yxa; vt Zaliznjak 2012: 660 jj); Kõ ${ }^{\mathrm{E}}$ Jasi-niittu [-niittü] < ? mehenimi *Jassi (vrd vn Яся < Святослав või Яков); $\mathrm{J}^{\mathrm{A} 1}$ Kirilaa niittü; $\mathrm{Ra}^{\mathrm{E}}$ Mitrjuška $<$ eesnimi vn Митрюшка $<$ Дмитрий; I ${ }^{\mathrm{A} 1} \mathrm{~K}^{\mathrm{A} 2}$ Papii niittü < pappi 'preester, papp; haldjas'; $\mathrm{M}^{\mathrm{A} 1} \mathrm{M}^{\mathrm{A} 2} \mathrm{M}^{\mathrm{EK}}$ Paturiniittü < paturi 'pottsepp' (vt ka 2.1); K ${ }^{\mathrm{T}}$ Ruotsitaad $<$ Rootsi + ?taat(a) 'taat, isa' (juhul, kui järelosise kirjapanek on ebatäpne, võiks oletada is taa 'taha' või isikunime Tadoi < Tatjana); $\mathrm{Li}^{\mathrm{A} 1}$ Van'a laita $\sim \mathrm{Lu}-\mathrm{Li}^{\mathrm{A} 1}$ Van'aa laita 'heinamaa'; $\mathrm{Ra}^{\mathrm{EM}}$ Viitruškaaniittü < Vitruška < vn ?Виктор, ?Виктория. Suure kõhklusega võib inimesega seotud heinamaanimede hulka paigutada $\mathrm{J}^{\mathrm{A} 1}$ Tvorttso-niittü $<$ ? perekonnanimi Tvortsov (vn Творияов) või tuleneb see siiski üldsõnast *tvortso (o-deminutiiv) < *tvorttsa 'loss' < vn двopeu; $\mathrm{Li}^{\mathrm{A} 2}$ Lad'd'a pers '[põld ja heinamaa]' (vt 5.1).

Osa heinamaade nimesid seostub ehitisega: $\mathrm{Lu}^{\mathrm{ES}}$ Sarainiittü 'suur mereäärne heinamaa', $\mathrm{Lu}^{\mathrm{ES}}$ Sarainiittü (= Suurniittü) 'heinamaa Luuditsa ja Kõhtsõ piiril', Lu-Li ${ }^{\mathrm{Al}}$ Sarajaa laita 'heinamaa', Lu ${ }^{\mathrm{EK}}$ Sarajaniittü 'mingi heinamaa' < sarai 'küün' < vn capaü; $\mathrm{Ra}^{\mathrm{A} 1}$ Taloniittü (ka põld, vt 5.1) < talo 'talu; majapidamine; maja'. Heinamaanimi võib olla ka Kõ ${ }^{\mathrm{E}}$ Sara-taka < saraa 'küün' + takaa 'taga'.

Paari heinamaanime atribuudi tähendus jääb kahtlaseks või arusaamatuks: Ra ${ }^{\mathrm{EK}}$ Halikaa niittü, $\mathrm{J}^{\mathrm{A} 1} \mathrm{Ra}^{\mathrm{A} 1}$ Halikaaniittü 'Jõgõperält kolme kilomeetri kaugusel asuv heinamaa' (vt 2.3); Kõ ${ }^{\mathrm{E}}$ Tuhu 'võsastunud heinamaa' (vrd tuho 'häving', samuti ee Tuhu, EKNR); Lu ${ }^{\mathrm{EM}}$ Tuika-niittü, $\mathrm{Ko}^{\mathrm{EK}} \mathrm{Lu}^{\mathrm{EK}}$ Tuikki Tuikiniittü 'heinamaa Luuditsast mere poole', Lu ${ }^{\mathrm{ES}}$ Tuikõõniittü 'heinamaa Luuditsa jõe paremal kaldal mere ääres', Lu ${ }^{\mathrm{ES}}$ Tuikõõsikku 'heinamaa Luuditsa jõe suudmealal' (vrd is 
tuikkoi, sm tuikku 'ähmane valgus'). Huvitav heinamaanimi on $\mathrm{Ra}^{\mathrm{EM}}$ Pühä-parraa-niittü $\sim \mathrm{Ra}^{\mathrm{E}}$ Pühä-parta < pühä 'püha' + parta 'habe'.

Primaarsete heinamaanimede seas leidub rohkesti determinandituid: Alakko, Jallain, Koivikko, Kurppa, Lad'd'a pers, Lakkia, Luhta, Nõgapaju, Palanikko, Raizikko, Tuikki, Tuikõõsikku, Vain'o. Liigisõnata Lakkia sisaldab erandina adjektiivi. Peale Ülisillalla, mida on kasutatud ka põllunimena, on alalütlevas käändes veel determinandita Roojõlla. Eessõnaline on ka Ile-oja [Ülee-õja]. Toponüümis Takadaatso niittü leidub eessõna takaa 'taga' koos nimisõnaga mitmuse partitiivis. Kohanimes Sara-taka võib näha tagasõna takaa ilmselt koos ainsuse genitiiviga.

Heinamaanimede hulgas on suhteliselt palju sekundaarseid. Enamik neist on moodustatud teiste looduslike objektide nimest. Nende hulgas võib leida asendist johtuvalt veekogunimedest lähtuvaid heinamaanimesid: $\mathrm{K}^{\mathrm{T}}$ Iiliä lähtee ranta < Iiliä 'Elias' + lähe : lähtee 'allikas' + ranta 'siin: äär' (nimekartoteegis allikanimi puudub; vt 4.6); $\mathrm{Li}^{\mathrm{A} 2} \mathrm{Lu}^{\mathrm{EK}}$ Jõgõranta (vt 5.1); $\mathrm{Ku}^{\mathrm{T}}$ Järvenranta (kartoteegis rannanimena pole; vt 3.1); Kõ ${ }^{\mathrm{EK}}$ Kapusõja 'oja ja heinamaa' < kapussa 'kapsas' (vt 4.5); $\mathrm{Ku}^{\mathrm{P}}$ Kiriloja 'mingi heinamaa' $<$ mehenimi Kirila + oja (ojanime kohta pole teateid; vt 4.5); Kõ ${ }^{\mathrm{EK}}$ Kopponi 'heinamaa' (Koppõni järve järgi, vt 4.5); Lu ${ }^{\mathrm{ES}}$ Laukaa niittü 'heinamaa Lauga jõe ääres' (vt 4.4); I ${ }^{\mathrm{A} 2}$ Piččä neemi < piččä 'pikk' (nimekartoteegis neemenimena puudub; vt 3.2); $\mathrm{Lu}^{\mathrm{ES}}$ Roossõjaa niittü 'heinamaa Liivčülä vastas teisel pool Tõrvajõge' (kartoteegis ojanimi puudub; vt 4.5); $\mathrm{Ku}^{\mathrm{T}} \mathrm{K} \tilde{o}^{\mathrm{EK}}$ Süvä-õja 'heinamaa Kõrvõttula lähedal' (vt 4.5); Lu ${ }^{\mathrm{EK}}$ Saviõjaniittü 'heinamaa Luuditsa küla lähedal' (vt 4.5); Lu ${ }^{\mathrm{ES}}$ Ved'd'apajaa niittü 'heinamaa Liivčüläst Jõgõperä poole metsa ääres', Lu-Li ${ }^{\mathrm{A} 1}$ Võd'd'a a apaja 'mingi heinamaa', $\mathrm{Li}^{\mathrm{A} 1}$ Võd'd'e-apaja 'mingi heinamaa' (nimekartoteegis abajanimena pole; vt 4.2).

Teiseste heinamaanimetuste seas on veel mitu soo- ja saarenimest alguse saanud nime, nagu $\mathrm{Ku}^{\mathrm{T}}$ Jessinpellonsoo (vt 2.2 ja 5.1); $\mathrm{K}^{\mathrm{T}}$ Karussaare $<$ karu (kartoteegis sellist saarenime pole; vt 3.4); $\mathrm{Ku}^{\mathrm{T}}$ Müllinsoo (soonimena pole registreeritud, vt 2.2); JEK Peräsoo Peräsoo niittü (vt 2.2); $\mathrm{Ku}^{\mathrm{T}}$ Touksaari, $\mathrm{Ku}^{\mathrm{E}}$ Touk-saari (vt 2.2). Samas rühmas leiduvad sünonüümsed Emoväl'l'ä < emo 'siin: suur' < emake, ema + väl'l'ä 'väli, põld') ja Ku${ }^{\mathrm{P}}$ Suuri väljä, $\mathrm{Ku}^{\mathrm{T}}$ Suurväljä < suuri 'suur' + väljä 'väli, põld' (sellist põllunime pole talletatud; vt 5.1; vrd is Suurväljä (heinamaa), IMS: väljä. 
Kivi- või kivise maastikuga seostuvad $\mathrm{Vp}^{\mathrm{B}}$ Чивикономми [Čivikkonommi $=$ Čivikkonõmmi] 'Liivčüla-tagused heinamaad $<\check{c}$ ivikko 'kivistik; kivine' (nõmmenimena pole tuntud); $\mathrm{K}^{\mathrm{T}} \mathrm{Ku}^{\mathrm{T}}$ Rigovačivi (vt 2.6); $\mathrm{Ku}^{\mathrm{T}}$ Matosürgü < mato 'madu, uss' (vt 2.2). Tõenäoliselt asendi järgi on nimetatud $\mathrm{K} \tilde{\tilde{}}^{\mathrm{EK}}$ Kalatee 'mingi heinamaa' $<$ kala + tee. $\mathrm{Ko}{ }^{\mathrm{EK}}$ Roočita 'heinamaa ja oja [?]' < roočito 'alemaa; karjaaed, koppel' viitab ehk üldsõnas väljenduvale erilisele kasutusalale. Noomen näikse olevat lähtunud verbist rooččia 'rookida', vrd sm Ruokkaanneva $<$ ruokata 'rookida, harida' (SPK).

Soome lahe rannikuribaga seonduvad $\mathrm{Li}^{\mathrm{EK}} \mathrm{Lu}^{\mathrm{EK}}$ Greivi 'heinamaa ja karjamaa Liivčülä kohal [samanimelises] rannas', Lu ${ }^{\mathrm{ES}}$ Greivi 'suur mereäärne niit Lauga jõest Kõhtsõ külani', $\mathrm{Li}^{\mathrm{A} 2}$ Greivi $\sim$ Kreivi, $\mathrm{Ra}^{\mathrm{EK}}$ Kreiviniittü 'heinamaa Jõgõperä küla Lauga jõe suudme vahel', $\mathrm{Ra}^{\mathrm{A} 1}$ Kreivi-ranta 'heinamaa Jõgõperäl; heinamaa ja karjamaa Liivčülä kohal rannas' (vrd is Kreivi (heinamaad); vt ka 5.2) < sm kreivi 'krahv' (vt ka 2.1, 3.1, 4.3, 4.4); ning Li ${ }^{\mathrm{ES}}$ Muиzõõnukaa niittü 'mereäärne heinamaa Liivčülä all', Lu-Li ${ }^{\mathrm{ES}}$ Muuzõõnukkõ 'heinamaa mererannas Liivčülä all' < nukka 'nukk, nina; maanina; mäenukk, küngas'; Lu-Li ${ }^{\mathrm{A} 1}$ Muuzõnukkõ 'mingi heinamaa'. Ka Soikkola poolsaare kahel külal oli Kreivi-nimeline heinamaa, mis võis olla kuulunud mingile krahvile (Nirvi 1971: 206).

Küla või selle osa nimega seonduvad $\mathrm{Ku}^{\mathrm{E}}$ Dubrovo (vt 3.2, 5.1); $\mathrm{Lu}^{\mathrm{EK}}$ Kazikko niittü 'Kazikko elanike kasutatud heinamaa Luuditsa lähedal mere ääres' (vt ka 5.1), Lu ${ }^{\mathrm{ES}}$ Kazikooniittü 'heinamaa Luuditsast Kõhtsõõ poole'; Li ${ }^{\mathrm{ES}}$ Korffii niittü 'Jõgõperä Korfi otsa elanike kasutatud heinamaa Jõgõperä ja Liivčülä vahel raudtee ääres'; $\mathrm{Lu}^{\mathrm{ES}}$ Koškinaa čülää niittü 'mereäärne heinamaa Liivčülä all'; $\mathrm{Lu}^{\mathrm{EK}} \mathrm{Ra}^{\mathrm{EK}}$ Ruuttsia niittü $\sim$ Ruuttsianiittü 'Soikkola poolsaare Ruutsia küla elanike heinamaa'.

Omapärase struktuuriga heinamaanimed on $\mathrm{Lu}^{\mathrm{ES}}$ Ivanpoolõo niittü 'heinamaa Lauga jõe ääres' (vt 5.1), Kõ ${ }^{\mathrm{A} 1}$ Marfaa risii aluz < naisenimi Marfa (< vn Mappa) + rissi : risii 'rist : risti' + aluz 'alune', vrd $\mathrm{X}^{\mathrm{A} 2}$ Marfaa risii alla 'koht Mati lähedal metsas, kus hundsid murdsid tüdruku, kelle mälestuseks oli varem rist seisnud' < alla 'all' (vt 2.6); ${ }^{24}$

24 Kõrvõttula keelejuht Kat’a Jovleva on pajatanud: Meill on niittü Marfaa risii aluz [...] Siäll susi vei suurõõ čivee päält tütrikkõizõõ. Sinne paikkaa, kuz õli söönnü, panti rissi 'Minu vanaema rääkis alati. Seal viis susi suure kivi pealt tüdrukese. Sinna paika, kus [ta] oli söönud, pandi rist' (VE II: 69; Ariste 1977: 34, vt ka lk 33). 2001. aastal mäletati Kõrvõttulas vaid venekeelset nime Марфин крест. 
$\mathrm{Vp}^{\mathrm{B}}$ Hайсиема [Naisijema] (= Naisijõõmaa) 'heinamaa saepurutee ääres' < nain : naizijõo 'naine : naiste' + maa; $\mathrm{K}^{\mathrm{T}}$ Russkaja-maa $<\mathrm{vn}$ Русская 'Vene; vene' + таa.

Sekundaarsete ja veelgi kaudsemate heinamaanimede seas leidub erakordselt palju toponüüme, milles determinant puudub: Emoväl'l'ä, Greivi Kreivi, Iiliä lähtee ranta, Jõgõranta, Järvenranta, Kalatee, Kapusõja, Karussaare, Kiriloja, Kopponi, Marfaa risii aluz, Matosürgü, Muuzõõnukkõ, Naisijõõmaa, Ojavaihe, Piččä neemi, Rajaoja, Rigovačivi, Roočita, Russkaja-maa (poolenisti venekeelne), Suurväljä, Süvä-õja, Touksaari. Liigisõnata toponüüm Marfaa risii alla sisaldab postpositsiooni alla 'all'. Kohanime Naisijõõmaa täiendosa sisaldab ainukesena nimisõna mitmuse genitiivis.

\subsection{Karjamaanimed}

Vadja keeles peaaegu polegi karjamaanimesid, sest loomi karjatati metsas ja soos ning heinamaal pärast niitmist. Mõnevõrra on talletatud loomade päevaseid magamispaiku (karjõmakaučči makaučči makahukki jt), kus lõuna ajal lüpsti lehmi (vrd is makaahoz makahuus makaauz; E-Ing Makaussürjä 'mingi kõlbmatu maatükk'). See oli Vadjamaal 2001. aastal säilinud ka terminnimena (Kõ ${ }^{\mathrm{E}}$ Karjamakaučci). Vaivara murraku kohanimena on kirja pandud Karjamagavik seletusega 'küngas, kus lehmad magasid lõuna ajal' (EK). ${ }^{25}$

Primaarsete magamiskohtade nimede alla kuuluvad $\mathrm{Li}^{\mathrm{EK}}$ Kuru makaučči 'karjamaa (lehmade magamispaik)'; $\mathrm{Ku}^{\mathrm{P}}$ Polt's 'ikko 'lehmade puhkamiskoht', Li ${ }^{\mathrm{EK}}$ Poltikka-makaučči 'Liivčüläst $5 \mathrm{~km}$ kaugusel olev karjamaa' < *polt's 'ikko 'nõgesekoht' < Ku polt's 'ikaz 'nõges', mujal poltikaz : poltikkaa $\sim$ põltikaz, is pol'dikaz; $\mathrm{Ku}^{\mathrm{P}}$ Vesimakahukki $<$ vesi. Selgusetum on $\mathrm{Ku}^{\mathrm{P}}$ Piimoo makahukki 'lehmade puhkamise koht', mille lähtesõna on nii päris- kui ka üldnimelise etümoloogia korral vaid oletuslik. Esimesel juhul tuleks arvesse vähendusliitega mehenimi *Piimo, vrd vn Пима < Пимен (vadja nimede $o$-deminutiivi kohta vt Saar 2016: 179), teisel juhul aga üldsõna * piimo 'piimake' < piimä 'piim' (üldsõnade $o$-deminutiivi kohta vt Ariste 1948: 124-125).

25 Võrdluseks oleks huvitav lisada ka mõned Võrumaa kohanimed: Vastseliina Härgimagahus (endine heinamaa) ja Kanepi Kivimagahus ehk Kiviorg (org) (AVKA). Retsensendi täiendus. 
Sekundaarsed karjamaa- ja magamiskohanimed on Soome lahe äärne $\mathrm{Li}^{\mathrm{EK}} \mathrm{Lu}^{\mathrm{EK}}$ Greivi 'heinamaa ja karjamaa Liivčülä kohal [samanimelises] rannas', Li ${ }^{\mathrm{A} 2}$ Greivi $\sim$ Kreivi 'heinamaa Jõgõperäl; heinamaa ja karjamaa Liivčülä kohal rannas', $\mathrm{Ra}^{\mathrm{EK}}$ Kreiviniittü 'heinamaa Jõgõperä küla Lauga jõe suudme vahel' (vt 3.1 ja 5.2); Ku $\mathrm{Ku}^{\mathrm{P}}$ aa haarad $<$ oja + haara 'haru'; Ra ${ }^{\mathrm{EK}}$ Povarsoo 'koht Rajo küla lähistel, kuhu loomad aetakse lõunase lüpsi ajaks', $\mathrm{Ra}^{\mathrm{EK}}$ Povarsoo makaučči (vt 2.2); $\mathrm{Ra}^{\mathrm{EK}}$ Suurõsoo makaučč ' $k$ oht, kuhu lehmad aeti lõunase lüpsi ajaks' (vt 2.2). Karjamaanimedest on Greivi $\sim$ Kreivi, Ojaa haarad ja Polt's'ikko determinandita.

\section{Kokkuvõtteks}

Vadja keeles oli rohkesti oma kohanimesid nii väiksemate kui ka suuremate loodus- ja viljelusobjektide tähistamiseks. Leidub nii primaarseid kui ka sekundaarseid kohanimesid, sageli on kirja pandud ka determinandita toponüüme, mõnikord terminnimesid. Loodus- ja viljelusnimed on päritolult üsna sarnased. Nad on arenenud looduskogumeid, loomi, taimi, omadusi, asendit jm väljendavatest apellatiividest, mõnikord ka reaalsete isikute või pühakute nimedest.

Toponüümide moodustamise printsiibid sarnanevad teiste läänemeresoome keelte kohanimede moodustamise põhimõtetega, nagu on väitnud juba P. Ariste (1967: 83). Nimede atribuut esineb peamiselt ainsuse nimetavas ja omastavas, determinant aga tavaliselt ainsuse ja harva mitmuse nimetavas käändes. Omavahel on eriti tihedasti integreeritud vadja ja isuri kohanimesüsteem. Esialgsetel andmetel on vadja toponüümika ning eesti keele vadja- ja isuripäraste murrakute kohanimede vahelisi ühisjooni oodatust vähem.

Üks ja sama toponüüm võib mõnikord tähistada heinamaad, sood, metsa ja põldu. See näitab nende kunagist vahelduvat kasutusala. Soost on saanud heinamaa või on seal kasvavas metsas karjatatud loomi; heinamaa võis saada viljeldavaks põlluks ja vastupidi.

Kohanimede päritolu uurimisel on selgunud üldnimesid, mida pole registreeritud väljaspool toponüümikat. Selle põhjuseks võib olla sõna hääbumine keelest ja säilimine üksnes kohanimes või on lekseem mingil põhjusel sõnakogudest välja jäänud. Nende seas on nii tüvisõnu kui ka tuletisi. 
Kohanimede hulgast on koorunud välja tosinkond tüvisõna: *iisi $\mathrm{Ku}^{\mathrm{P}}$ *hiisi 'hiis', *jalain 'jalakas', *juka 'juga, kosk', *kaarna $\sim^{*}$ kaarlõ 'kaaren, ronk', *kuru 'kuru', *laugaz : *laukaa 'laugas', *pungõr (tähendus ebaselge, võib-olla 'kõrgem koht'), ?*tvorttsa 'loss' (< vn), usti 'suue' (< vn), *vaije 'vahe' ja *võhmaz 'soosaar'. Sõna *jalain 'jalakas' (vrd vdj kõltainõ $\sim$ kõltanõ $\sim$ kõltõin $\sim$ kõltõn 'kollane') võib põlvneda ka mõnest teisest läänemeresoome keelest. Sama kehtib ka suure Lauga jõe nime võimaliku lähtesõna *laugaz kohta. Sõnal mätä näikse esinevat nimisõnana tähendus 'soo' ('mädasoo?') ja laita võib tähistada ka maatükki või -riba. Mitu huvipakkuvat lekseemi nagu *nõka, *talittu jt on jäänud paraku seletuseta. Kohanimede komponendina on avastatud ka oletatavaid vadjapäraseid isikunimesid: *Jassi, *Jessi, ?*Piimo, *Ul'o ja *Us'o.

Nimisõnatuletised on peamiselt moodustatud kollektiivsufiksi -kko abil: ?*hirzikko 'palgistik; palgimets' või ?*hirvizikko 'põdrakari', *maranikko 'maranate kasvukoht', *palanikko 'põlenud koht', *polt's 'ikko 'nõgeste kasvukoht' ja *raisikko 'rägastik'. Liite -zikko abil on tekkinud ehk *niittüzikko 'mitmeosaline heinamaa'. Seni talletamata liitnimisõnad on *kalatee, *lidnaamäči 'linnamägi', *savipaja 'savikoda' jt. Nimisõnadest on tuletatud järgmised omadussõnad: *cärppän čärppäne : *čärppäzee 'kärbi-; nirgi-', *hijjene : *hijjezee < *hiisi 'hiis' ja *nõmmin : *nõmmizõo 'nõmmene, nõmme-'. Selliseid, adjektiivse atribuudiga toponüüme esineb ka teistes läänemeresoome keeltes, nt ee Tammispää.

\section{Aadress:}

Enn Ernits

Eesti Maaülikool

Kreutzwaldi 62

51014 Tartu

E-post: enn.ernits@emu.ee

\section{Lühendid}

${ }^{\mathrm{A} 1}=$ Paul Ariste kogu „Vadja etnoloogiat“", $\mathrm{A} 2=$ Ariste 1967, $\mathrm{B}=$ A. Baranovi kirjapanekud (Demina 2009: 40-44), ${ }^{\mathrm{E}}=\mathrm{E}$. Ernitsa 
kirjapanekud, ee = eesti, E-Ing = Eesti-Ingeri (J. Mägiste kirjapanekud), $\mathrm{EK}=$ Eesti Keele Instituudi vadja kohanimekogu, $\mathrm{EM}=$ Eesti Keele Instituudi eesti murrete ja soome-ugri keelte arhiiv (EMSUKA): SUH*21, $\mathrm{SUH}^{*} 55, \mathrm{SUH} * 62$ (T.-K. Raudalaineni litereeringu järgi), ES = Emakeele Seltsi vadja kohanimekogu, I = Ičäpäivä, is = isuri, J = Jõgõperä, Jõh = Jõhvi murrak, Ja = Jarvikoiščülä, $\mathrm{K}=$ Kattila, ${ }^{\mathrm{K}}=$ Kettunen 1986, Kod = Kodavere murrak, Ku = Kukkuzi, Kõ = Kõrvõttula, $\mathrm{L}=$ Lempola, $\mathrm{Li}=$ Liivčülä, $1 \mathrm{~ms}=$ läänemeresoome, $\mathrm{Lu}=$ Luuditsa, Lüg = Lüganuse murrak, $\mathrm{M}=$ Mati, $\mathrm{Ma}=$ Mahu, $\mathrm{P}=$ Pummala, ${ }^{\mathrm{P}}=$ Posti 1980, $\mathrm{R}=$ Rudja, $\mathrm{Ra}=$ Rajo, rts $=$ rootsi, $\mathrm{Sa}=$ Savvokkala, $\mathrm{se}=$ setu, $\mathrm{sm}=$ soome, ${ }^{\mathrm{T}}=$ Talve 1981, Trm $=$ Torma murrak, ${ }^{\mathrm{Ts}}=$ Tsvetkov $1995, \mathrm{~V}=$ Velikkä, Vai $=$ Vaivara murrak, $\mathrm{Vp}=$ Vaipooli, $\mathrm{vdj}=$ vadja, $\mathrm{vn}=$ vene, vps $=$ vepsa, $\mathrm{X}=$ külanimi teadmata

\section{Käsikirjalised allikad}

„Eesti Keele Instituudi vadja kogu“. Eesti Keele Instituudi kohanimekartoteek. Saadaval Internetis $<$ http://heli.eki.ee/kohanimed/index.php?khk=vdj\&om=ekil $>$ Vaadatud 18.08.2019. Vt lühendid.

$\mathrm{EK}=[$,Eesti kohanimed“ $]$ Eesti Keele Instituudi kohanimekartoteek. Saadaval Internetis < http://heli.eki.ee/kohanimed/index.php? > Vaadatud 19.03.2020.

„Emakeele Seltsi kogu“. Eesti Keele Instituudi kohanimekartoteek. Saadaval Internetis $<$ http://heli.eki.ee/kohanimed/index.php?khk=vdj\&om=es1 > Vaadatud 18.08.2019. Vt lühendid.

VE I-VIII = Ariste, Paul. Vadja etnoloogiat 1-18 (Eesti Kirjandusmuuseum). Vt lühendid.

\section{Kirjandus}

Ariste, Paul (1948) Vadja keele grammatika. (Nõukogude soome-ugri teadused, 9.) Tartu: Teaduslik Kirjandus.

Ariste, Paul (1960) Vadjalaste laule. (Eesti NSV Teaduste Akadeemia Emakeele Seltsi toimetised, 3.) Tallinn.

Ariste, Paul (1964) „Baabino ehk Jarvigoiščülä: (Ühest vadja külanimest)“. Emakeele Seltsi aastaraamat 10, 167-172.

Ariste, Paul (1965a) „Vadja kohanimedes“. Slaavi-läänemeresoomete suhete ajaloost, 91-106. Tallinn.

Ariste, Paul (1965b) „Über wotische Ortsnamen“. Zweiter Internationaler Finnougristenkongress, Helsinki, 23.-28.08.1965: Referate der Vorträge und Mitteilungen, 4-5. [Helsinki.] 
Ariste, Paul (1967) „Über wotische Ortsnamen“. Sovetskoe finno-ugrovedenie 2, 77-84. Ariste, Paul (1968) „Über wotische Ortsnamen“. Congressus Secundus Internationalis Fenno-Ugristarum Helsingiae habitus 23-28. VIII 1965. 1: Acta linguistica, 24-30. Helsinki.

Ariste, Paul (1977) Vadja muistendeid. (Eesti NSV Teaduste Akadeemia Emakeele Seltsi toimetised, 12.) Tallinn: Valgus.

Ariste, Paul (1986) Vadja rahvalaulud ja nende keel. (Eesti NSV Teaduste Akadeemia Emakeele Seltsi toimetised, 22.) Tallinn: Valgus.

AVKA = Ajaloolise Võrumaa kohanimede andmebaas Maa-ameti kohanimeregistri kaardirakenduses. Saadaval Internetis $<$ http://www.wi.ee/index.php/ajaloolisevorumaa-kohanimede-andmebaas $>$. Vaadatud 24.03.2020.

CFV $=$ Charta Öfwer Finska Viken Med Däromkring Belägne Provincier. Stockholm, 1788. Saadaval Internetis <http://dspace.ut.ee/bitstream/handle/10062/8554/ kaart12.pdf $>$. Vaadatud 31.03.2020.

Demina, B. B., koost. (2009) Toponimika Kingiseppskogo rajona: Èlektronnoe dopolnjaemoe izdanie. Kingisepp. Saadaval Internetis $<$ https://docplayer.ru/26608378Toponimika-kingiseppskogo-rayona-elektronnoe-dopolnyaemoe-izdanie-sost-v-vdemina.html>. Vaadatud 18.08.2019.

Dmitriev, A. V. (2007) „Vodskaja toponimika v istoriko-kul'turnom aspekte“. Pskovskij regionologičeskij žurnal 4, 110-118.

EDW = Ferdinand Johann Wiedemann (1973) Estnisch-deutsches Wörterbuch. Eestisaksa sõnaraamat. 4., muutmata trükk teisest, Jakob Hurda redigeeritud väljaandest. Tallinn: Valgus.

$\mathrm{EES}=$ Eesti etümoloogiasõnaraamat. Saadaval Internetis $<$ https://www.eki.ee/dict/ety/ $>$. Vaadatud 18.08.2019.

EJO = Arukaevu, Gustav, koost. (1986) Eesti NSV jõgede, ojade ja kraavide ametlik nimestik. Tallinn: Valgus.

EJN = Kask, Ilmar, koost. (1964) Eesti NSV järvede nimestik. Tallinn: Eesti Riiklik Kirjastus.

$\mathrm{EKN}=$ „Kapa“. e-Keelenõu. Saadaval Internetis <http://test.keeleleek.ee/ekeelenou/?Q=kapa>. Vaadatud 19.03.2020.

EKNR = Eesti kohanimeraamat. Saadaval Internetis $<$ https://www.eki.ee/dict/knr/ index.cgi>. Vaadatud 18.08.2019.

EMS V = Eesti murrete sõnaraamat 5, 22: likah(h)ama -loom. Mari-Liis Kalvik, Mari Kendla ja Tiina Tärk, toim. Tallinn: Eesti Keele Instituut, 2011.

Ernits, Enn (2020) „Vadja asustusnimed“. Emakeele Seltsi aastaraamat 65, ilmumas.

GCI $=$ General Charta Öfver Provincien Ingermanneland. 1704 [Koostatud Andres Andersi 1678. aasta ja hilisemate mõõtmiste põhjal]. Saadaval Internetis $<$ http://www.aroundspb.ru/karty/152/sg_1678_beling.html>. Vaadatud 30.03.2020.

IMS = Nirvi, R. E. (1971) Inkeroismurteiden sanakirja. (Lexica Societatis FennoUgricae, 18.) Helsinki: Suomalais-Ugrilainen Seura.

$\mathrm{JI}=$ Jordeböcker öfver Ingermanland. Piscovye knigi Ižorskoj zemli 1. Gody 16181623. Sankt-Peterburg, 1859.

JZL = Ivanov D., red. (1998) Jugo-Zapad Leningradskoj oblasti. Topografičeskaja karta, masštab 1: 100 000. Sankt-Peterburg. 
Kallasmaa, Marja (2003) Lä̈̈nemurde loodus- ja viljelusnimed. Tallinn: Eesti Keele Sihtasutus.

Kettunen, Lauri (1986) Vatjan kielen Mahun murteensanasto. Jarmo Elomaa, Eino Koponen ja Leena Silfverberg, toim. (Castrenianumin toimitteita, 27.) Helsinki.

KSP = Karta Sankt-Peterburgskoj gubernii soderžaščej Ingermanlandiju, čast' Novgorodskoj i Vyborgskoj gubernij. 1770. Saadaval Internetis $<$ https://www. aroundspb.ru/maps/history/shmidt1770.jpg>. Vaadatud 30.03.2020.

Laanest, Arvo (1997) Isuri keele Hevaha murde sõnastik. Tallinn: Eesti Keele Instituut. Myznikov, S. A. (2004) Leksika finno-ugorskogo proisxoždenija v russkix govorax Severo-Zapada: Ėtimologičeskij i lingvogeografičeskij analiz. Sankt-Peterburg: Nauka.

Nissilä, Vilho (1975) Suomen Karjalan nimistö. (Karjalaisen Kulttuurin Edistämissäätiön julkaisuja.) Joensuu.

$O B G=$ Karta byvšix gubernij Ingermanlandii Ivangoroda, Jama, Kopor'ja, Nèteborga sostavlennaja [...] 1827 goda pod prismotrom generalmajora Šuberta [...] pokazyvajuščaja razdelenie i sostojanie onogo kraja v 1676 g. 1676 [1827]. Saadaval Internetis <http://www.aroundspb.ru/maps/ingermanland/1676/1676_ inger3.jpg $>$. Vaadatud 30.03.2020.

OS = „Ostrov Seskar“. Suportnet II North-West Rus. Saadaval Internetis $<$ http://www. kingisepplo.ru/contacts/SuPortNet/Seskar.htm>. Vaadatud 24.03.2020.

Petersson, Katarina (2003) Proekt razvitija porta Ust'-Luga. Mnogocelevoj terminal. Ocenka vozdejstvija na okružajuščuju sredu. Gëteborg. Saadaval Internetis $<$ https://mintrans.ru>. Vaadatud 7.09.2019.

Petrovskij, N. A. (1966) Slovar' russkix ličnyx imen. Okolo 2600 imen. Moskva: Sovetskaja Ènciklopedija.

Posti, Lauri (1980) Vatjan kielen Kukkosin murteen sanakirja. Painokuntoon toimittanut Seppo Suhonen Lauri Postin avustamana. (Lexica Societatis Fenno-Ugricae, 19.) Helsinki: Suomalais-Ugrilainen Seura.

Päll, Peeter (2020) „Eesti kohanimed“. Rmt. Pajusalu, Karl, Tiit Hennoste, Ellen Niit, Peeter Päll ja Jüri Viikberg. Eesti murded ja kohanimed, 231-305. 3., kohendatud ja täiendatud trükk. Tartu.

Ruoppila, Veiko (1943) „Ylisen Syvärin suomalaisperäisiä paikannimiä“. Virittäjä 1, 78-96.

Saar, Eva (2016) „Vene õigeusu eesnimed vadja, isuri ja seto keeles“. Emakeele Seltsi aastaraamat 61, 167-186. https://doi.org/10.3176/esa61.08

Saar, Evar (2009). Võrumaa kohanimed. (Tartu Ülikooli doktoritöid.) Tartu: Tartu Ülikooli Kirjastus.

SRN XIV = Slovar' russkix narodnyx govorov, 14. Moskva, Leningrad: Nauka, 1978.

SPK = Suomalainen paikannimikirja (2007). Sirkka Paikkala, päätoim. (Kotimaisten kielten tutkimuskeskuksen julkaisuja, 146.) Karttakeskus, Kotimaisten kielten tutkimuskeskus.

SSN = Suuri suomalainen nimikirja. Helsinki: Suuri Suomalainen Kirjakerho, 1985.

Stöbke, Detlef-Eckhard (1964) Die alten ostseefinnischen Personennamen im Rahmen eines urfinnischen Namensystems. Hamburg: Leibniz-Verlag. 
Zaliznjak, A. A. (2012) „Mexanizmy èkspresivnosti v jazyke“. Rmt. Smysly, teksty $i$ drugie zaxvatyvajuščie sjužety. Sbornik statej v čest'80-letija Igorja Aleksandroviča Mel'čuka, 650-664. Moskva: Jazyki slavjanskoj kul'tury. Saadaval Internetis $<$ http://www.ruslang.ru/doc/melchuk_festschrift2012/Zaliznjak.pdf $>$ Vaadatud 13.09.2019.

Talve, Ilmar (1981) Vatjalaista kansankulttuuria. (Suomalais-Ugrilaisen Seuran toimituksia, 179.) Helsinki: Suomalais-Ugrilainen Seura.

Tsvetkov, Dmitri (1995) Vatjan kielen Joenperän murteen sanasto. Johanna Laakso, toim. (Lexica Societatis Fenno-Ugricae, 25.) Helsinki: Suomalais-Ugrilainen Seura, Kotimaisten kielten tutkimuskeskus.

VKS = Vadja keele sõnaraamat (2013). 2., täiendatud ja parandatud trükk. 2. Silja Grünberg, toim. Tallinn: Eesti Keele Sihtasutus.

VMS I-II = Väike murdesõnastik 1-2 (1982-1989). Valdek Pall, toim. Tallinn: Valgus.

\begin{abstract}
Enn Ernits: Votic names of natural and cultivation objects. A more systematical recording of Votic toponyms took place in the second half of the 20th century. Since then, the place name collections of the Institute of the Estonian Language and the Mother Tongue Society have been dated. The author managed to record only 40 toponyms between 2001 and 2004. Votic toponymy has so far been studied mainly by Paul Ariste. In this century, only the amateurs of the Kingisepp district of the Leningrad region have dealt with the origin of some toponyms. This paper, which is mainly based on the previously mentioned collections and deals with the names of natural and cultivation objects, focuses on their origin. This allows us to classify place names by attributes into groups by their meaning. The study also identifies the generic terms of place names. The morphological features of toponyms are not neglected either. In Votic language, there are both primary and secondary place names, often toponyms without a generic term and sometimes term names. Names of natural and cultivation objects are quite similar in origin. They have evolved from the apellatives denoting nature, animals, plants, features, location and other aspects, sometimes deriving from the names of real persons or saints. The principles of toponym forming are similar to those in other Finnic languages. The attribute of names occurs mainly in the nominative and genitive of singular, but the generic term is usually in the singular and rarely the plural. The same toponym can simultaneously refer to meadows, marshes, forests and fields. This indicates their former, alternative use. Examination of the origin of place names revealed a number of common names not recorded outside the toponymy.
\end{abstract}

Keywords: toponyms, names of natural objects, names of cultivation objects, etymology, Votic, Finnic languages 